\title{
COVID-19 Salgını Süresince Eğitim Hakkı, Fırsat Eşitliği ve Sınavlara İlişkin Temel Problemler
}

\author{
Bilge Bingöl Schrijer ${ }^{*}$ (C)
}

\section{Öz}

Çalışmanın amacı COVID-19 nedeniyle okulların kapatılıp, zorunlu uzaktan eğitime geçilmesi ile birlikte ortaya çıkması muhtemel eğitim hakkı taleplerini irdeleyerek, çeşitli çözüm önerilerini tartş̧maya sunmaktır. Bunun için öncelikle Birleşmiş Milletler (BM) sistemi içinde eğitim hakkının norm alanı açıklanmış ve BM'nin çeşitli insan hakları sözleşmelerinin denetim organı olan komitelerin ortaya koyduğu, COVID-19 salgınından kaynaklanan eğitim hakkı sorunlarına değinilmiştir. Çalışmanın ikinci bölümü Avrupa İnsan Hakları Mahkemesi'nin eğitime erişim kısıtlamaları ve eğitime erişimde ayrımcılık konuları hakkındaki içtihatları ile COVID-19 salgını nedeniyle ortaya çıkması olası güncel eğitim hakkı taleplerini karşılaştırmaktadır. Burada dikkati çeken hususlar eğitime erişim engelleri, eğitime erişimde firsat eşitsizliği, üniversite sınavları ve firsat eşitsizliği ve okul sağlığı hizmetleri ile okullarda sağlığa ilişkin bilginin gizliliğidir. Illeride COVID-19 salgını süresince alınan önlemler nedeniyle, bu alanlarda uyuşmazlıklar ortaya çıkabilecektir. Bir diğer husus ise uluslararası hukukta eğitim hakkından değil, nitelikli eğitim hakkından söz ediliyor olmasıdır. Çalışmanın son bölümü Türk idare hukuku açısından hak ve özgürlük temelli kamu düzeni yaklaşımının önemini vurgulamaktadır. Bununla birlikte bir kamu hizmeti olarak eğitim alanında idarenin kusursuz sorumluluğu ile kusur sorumluluğuna ilişkin tartşmalar da ileride ortaya çıkacaktır. Bu hususlar çeşitli örnekler üzerinden irdelenmiştir.

\section{Anahtar Kelimeler}

Eğitim hakkı, COVID-19, Fırsat eşitliği, İdarenin sorumluluğu, Sınavlar

The Main Problems Regarding the Right to Education, Equality of Opportunity, and Exam Law During the Ongoing COVID-19 Pandemic

\begin{abstract}
This article focuses on the possible effects of government measures against the Covid-19 pandemic on the right to education. Special emphasis is given to the principle of equality of opportunity. The first part is a discussion of the problems presented by the CESCR, CEDAW, CRC, OHCHR, and OECD concerning the right to education due to Covid-19. The second part of the article focuses on the case-law of the European Court of Human Rights on the right to education and compares previous cases to potential claims due to the pandemic. Potential claims might concern restricted access to education due to illness; unequal access to education due to disabilities or financial disadvantage; the lack of equality of opportunity in university entrance exams; and also concerns about school health services and their obligation of confidentiality. Complaints about these issues may concern government measures taken against Covid-19. Additionally, the right to education must be understood as the right to quality education. The final part of the study discusses the Turkish administrative jurisdiction and emphasizes the importance of a human rights-based approach to public order, and reviews various discussions concerning the eventual liability of the administration for losses resulting from Covid-19 measures. Finally, these claims are examined through a review of different examples, concluding with suggested solutions to the identified problems.
\end{abstract}

\section{Keywords}

Right to education, COVID-19, Equality of opportunity, Liability of administration, Exams

* Sorumlu Yazar: Bilge Bingöl Schrijer (Dr. Öğr. Üyesi), Akdeniz Üniversitesi, Hukuk Fakültesi, Genel Kamu Hukuku Ana Bilim Dalı, Antalya, Türkiye. E-posta: bilgebingol@akdeniz.edu.tr ORCID: 0000-0003-2338-6199

Atıf: Bingol-Schrijer B, “COVID-19 Salgını Süresince Eğitim Hakkı, Fırsat Eşitliği ve Sınavlara Ilişkin Temel Problemler” (2020) 78(2) İstanbul Hukuk Mecmuası 837. https://doi.org/10.26650/mecmua.2020.78.2.0019 


\section{Extended Summary}

This article focuses on the possible effects of legal measures that have been taken during the Covid-19 pandemic on the right to education. Special emphasis is given to the principle of equality of opportunity. The first part of the article emphasizes the scope and meaning of the right to education in the context of contemporary developments. According to General Comment No. 13 of the UN CESCR, state parties guarantee an education which in all forms and at all levels demonstrates the four interrelated features of the right to education: availability, accessibility, acceptability, and adaptability. The most recent General Comment No. 25 of CESCR stresses the effect of new technologies and scientific developments on economic, social, and cultural rights. Therefore, it highlights potential inequalities between different social groups in terms of their access to the benefits of scientific inventions and technology. CEDAW, OHCHR, and OECD have published reports on gender-based inequalities during the pandemic and have called for immediate remedies to genderbased violence, girls' disadvantaged educational access, and working parents with children. Turkey should consider arranging all the regulations based on appointments and re-appointments in all performance-based work systems and prolong the periods of re-appointments up to six months or one year. Immediate solutions should focus on the most disadvantaged groups in Turkish society.

The second part compares previous ECHR precedents and the possible breaching of the right to education during the Covid-19 pandemic. For this purpose, four potential claims to the right to education will be classified. First, the restriction of access to education is due to a highly contagious disease. In the case of Covid-19, a person might be positive but show no symptoms. Therefore, the ECHR has acknowledged legitimate reasons for restricting the right to education including protecting public health and the rights of others. Although the ECHR also emphasizes the negative obligation of state parties according to Article 2 of Protocol No.1, unpredictable restrictions in access to education (such as undefined periods or a lack of certain processes) might cause the right to education to be breached (Memlika vs. Greece Case). Students must have sufficient opportunities for distance education and attending exams. The second potential claim is discrimination based on disabilities or financial status that limits access to distance education. The third potential claim is inequality of opportunity during university entrance exams. This claim was made recently in a case in Berlin, Germany. A school student who needed to attend the Abitur claimed that equality of opportunity was not upheld since she was unable to focus on her studies due to her home circumstances. Although the federal administrative court rejected this claim, it fundamentally agreed that Covid-19 measures did create inequalities of opportunity. At the same time, the court stated that the examinations administrators would not be obliged to provide absolute equality; rather, its emergency regulations were in 
place to ensure the healthiest possible conditions for exams. States are expected to take appropriate measures based on the latest scientific developments to secure equality of opportunity during exams. Therefore, special and separate rooms for the candidates from at-risk groups should be provided during the exams, so that they are not obliged to wear masks. In Turkey specifically, universities should provide more flexible solutions for grading students. There have been several claims that the availability of the internet and the related technology required was limited. The fourth potential claim addresses school health services and the school health service provider's obligation to protect confidentiality. Students' personal health data should only be disclosed to those individuals who need it to inform appropriate measures for the sake of the individual and others in the school. Turkish schools are not obliged to provide medicals; however, this might be necessary during the next semester to fight the pandemic and should be introduced in educational codes. An additional claim that might occur is the right to quality education.

Finally, this article focuses on discussions of Turkish administrative law. Health is one element of public order. In practice, maintaining public order often goes along with limiting human and civil rights. However, a human rights-based approach must be applied when maintaining public order. The Turkish administrative jurisdiction acknowledges the liability of the administration, yet it might also consider Covid-19 a force majeure and dismiss claims for compensation. In any case, the obligations of the administration to take preventive measures against risks and establish an organization for reducing risks endure. 


\section{COVID-19 Salgını Süresince Eğitim Hakkı, Fırsat Eşitliği ve Sınavlara İlişkin Temel Problemler}

\section{Giriş}

Dünya 2020 senesinin kış aylarından beri I. ve II. Dünya Savaşları zamanından bu yana görülen en geniş kapsamlı krizlerden birisiyle karşı karşıyadır. Bu salgın hastalığın etkilediği en önemli alanlardan bir tanesi de kuşkusuz eğitim-öğretim alanıdır. Eğitim hakkına ilişkin tartışmalar ve eğitime erişim engelleri aslında savaş ve çatışma ortamına maruz kalan çocuklar ve gençler açısından sürekli dünya gündeminde olmaktadır ${ }^{1}$. Ancak COVID-19 salgını nedeniyle eğitim hakkına yönelik zorunlu kısıtlamalar güncel olarak dünyanın her ülkesinde gündemdedir. Üstelik söz konusu salgının ülkelerin eğitim-öğretim sistemleri üzerinde kurduğu güncel maddi baskı bir yana, salgın sonlandığında dahi geleceğe yönelik birçok hukuki ve sosyal sorun zincirleme olarak ortaya çıkacaktır. Öte yandan Avrupa Konseyi üye devletlerinden bazıları salgın nedeniyle Avrupa İnsan Hakları Sözleşmesi'nin (AİHS) olağanüstü hallerde yükümlülükleri askıya almayı düzenleyen 15. maddesindeki hakkını kullanarak, Avrupa Konseyi Genel Sekreterliğine bilgi vermiştir². Çalışmanın amacı, COVID-19 salgını nedeniyle eğitim ve öğretim alanında ortaya çıkan ya da çıkma olasılığı olan hukuki sorunlara ilişkin bir inceleme yaparak çözüm önerilerini tartışmaya açmaktır. Bu kapsamda dünya genelinde, COVID-19 salgını kaynaklı (ya da salgın hastalıklar ile doğal afetler) eğitim hakkının ihlali olarak değerlendirilen çeşitli uygulamalara ve Birlemiş Milletler (BM) ile Birleşmiş Milletler Eğitim, Bilim ve Kültür Teşkilatının (BMEBKT/UNESCO) konuya yaklaşımına kısaca yer verildikten sonra, Türkiye'de ortaya çıkması muhtemel hukuki sorunlar üzerinde durulacaktır.

Eğitim hakkı gerek BM temel insan hakları sözleşmelerinde, gerek bölgesel insan hakları sözleşme ve bildirilerinde ve dünya anayasalarında kapsamlı bir biçimde düzenlenmiştir ${ }^{3}$. Çalışmanın kapsamını aşmaması için aşağıda yalnızca Türkiye'nin taraf olduğu uluslararası hukuki düzenlemelerden eğitim hakkını bütüncül bir bakışla ele alan sözleşmelere atıf yapılmıştır. Bu doğrultuda eğitim hakkını daha çok saygı gösterme yükümlülüğü çerçevesinde ele alan sözleşmeler ile göçmenler, mülteciler,

Birleşmiş Milletler Çocuklara Yardım Fonu (UNICEF) verilerine göre, eğitim kurumları ve okullara saldırıldığı için yalnızca 2014 ile 2018 yılları arasında 87 ayrı ülkede eğitime ara verilmek zorunda kalınmıştır. 'Education Under Attack', (UNICEF, 2020) <https://www.unicef.org/education-under-attack> erişim tarihi 18 Mayıs 2020.

29 Mayıs 2015 tarihinde Oslo'da gerçekleşen hükümetler arası girişimde "Güvenli Okul Bildirgesi” kabul edilmiş ve devletlerin onayına sunulmuştur; şu ana kadar 103 devlet bildiriyi kabul etmiştir. Türkiye söz konusu bildiriyi henüz onaylamamıştır. Türkçe metin için bkz <http://www.protectingeducation.org/sites/default/files/documents/safe_schools_ declaration_turkish.pdf> erişim tarihi 15 Ağustos 2020.

2 Kanstantsin Dzehtsiarou, 'COVID-19 and the European Convention on Human Rights' Strasbourg Obververs (27 Mart 2020) <https://strasbourgobservers.com/2020/03/27/covid-19-and-the-european-convention-on-human-rights/> erişim tarihi 11 Mayıs 2020. Patricia Zghibarta, 'The Whos, the Whats, and the Whys of the Derogations from the ECHR amid COVID-19' Ejiltalk <https://www.ejiltalk.org/the-whos-the-whats-and-the-whys-of-the-derogations-from-the-echr-amidcovid-19/> erişim tarih 11 Mayıs 2020.

3 BM belgelerinde eğitim hakkına ilişkin detaylı bilgi için bkz Recep Kaplan, 'Birleşmiş Milletler Belgelerinde Eğitim Hakkı' (2015) 6 (20) Türkiye Adalet Akademisi Dergisi 329. 
kadınlar gibi belli bir gruba yönelik ayrımcı müdahale ve uygulamaların ortadan kaldırılmasını içeren sözleşmelere, ilgili oldukları sorunlar temelinde atıf yapılmıştır". Söz konusu hukuki düzenlemeler temel hak ve hürriyetlere ilişkin olduğundan Anayasanın 90/5 hükmü gereği ulusal hukuk uygulayıcıları bakımından bağlayıcıdır5. $\mathrm{Bu}$ nedenle Türkiye'nin ilgili sözleşmelere taraf olup olmadığı ve çekincelerine de yer verilmiş ancak bu çekincelerin hukuki tahliline gidilmemiştir. Hemen başta belirtelim ki, uluslararası insan haklarına ilişkin sözleşmelere konulan çekinceler konusu oldukça tartışmalı bir husustur. Bu tartışmalar içinde Viyana Andlaşmalar Hukuku Sözleşmesi'nin 31. maddesinde düzenlenen genel çekince kurallarının yorumu ile ilgili tartışmalar olduğu gibi, tüm insan hakları sözleşmelerinde ayrıca yer alan "sözleşmenin hedef ve amacına aykırı çekince konulamayacağı" ilkelerinin nasıl ve hangi organ tarafından değerlendirileceğine ilişkin tartışmalar da bulunmaktadır ${ }^{6}$. Öte yandan genel olarak uluslararası hukukun iradeci temellerinin insan hakları hukuku ile yumuşadığ 1 da tartışmalar arasındadır ${ }^{7}$.

\section{Birleşmiş Milletler Sistemi Kapsamında ve Salgın Nedeniyle Tartışılması Gereken Eğitim Hakkı Meseleleri}

$\mathrm{Bu}$ başlıkta ileride ortaya çıkması muhtemel taleplerin içeriğine ilişkin genel bir kanı oluşabilmesi için uluslararası hukuktaki tartışmalar ele alınmıştır. Devletlerin eğitim hakkını düzenleyen sözleşmelerden kaynaklanan yükümlülüklerini yerine getirip getirmediği, BM insan hakları sözleşmelerinin koruma sistemleri kapsamında belli ölçüde denetlenmektedir. BM sistemi içerisinde eğitim hakkının norm alanının belirlenmesine ilişkin önemli bilgi kaynakları BM İnsan Hakları Evrensel

\footnotetext{
Eğitim hakkı ve özgürlüğ̈nü içeren uluslararası düzenlemeler listesi için bkz ibid.

İç hukuk normlarının iç geçerliliği uluslararası hukuk normundan etkilenmemektedir. Ancak çalışmanın kapsamı nedeniyle anayasa genel teorisi kapsamında bu tartışmaya yer verilmemiştir. Tartışma için bkz Kemal Gözler, Anayasa Hukukunun Genel Esaslarl (9. Bası, Ekin Kitabevi Yayınları 2017) 77, 78.

6 Bu hususlara çalışmanın kapsamı nedeniyle yer vermek mümkün değildir. Ancak insan haklarına ilişkin sözleşmelere çekince konulması hususu, eğitim hakkına ilişkin meselelerde bir ön sorun olarak varlığını korumaktadır. İnsan hakkı sözleşmelerine çekince konulup konulamayacağı, bu çekincelerin Uluslararası Hukuk Komisyonunun güncel uygulama ilkeleri kapsamındaki hukuki niteliği hakkında bkz Ineta Ziemele/Lasma Liede, 'Reservations to Human Rights Treaties: From Draft Guideline 3.1.12 to Guideline 3.1.5.6' (2013) 24 The European Journal of International Law 1135.

Çekinceler bakımından bir sınır teşkil eden "sözleşmenin hedef ve amacına aykırılık" sorunu ve Türkiye uygulaması hakkında bkz Zeynep Elibol Brönneke, 'Uluslararası İnsan Hakları Sözleșmelerine Koyulan Çekinceler Çerçevesinde Hedef ve Amaçla Bağdaşma Ölçütü ve Türkiye Uygulaması’ (Doktora Tezi, İstanbul Üniversitesi 2017).

Mahmut Göçer, Uluslararası Hukuk ve İnsan Haklarının Uluslararası Korunması, Uluslararası Hukukun Insan Hakları Alanına Uygulanmasından Kaynaklanan Kimi Sorunlar Üzerine Karşılaştırmalı Bir İnceleme (Seçkin Yayınları, 2002) 157, 159.
} 
Beyannamesi $^{8}$ (BMiHEB), BM Ekonomik, Sosyal ve Kültürel Haklar Sözleşmesi ${ }^{9}$ (BMESKHS), BM Çocuk Hakları Sözleşmesi ${ }^{10}$ (BMÇHS), ve BM İnsan Hakları Konseyinin oluşturduğu özel usullerden eğitim hakk1 özel raportörünün ${ }^{11}$ konuya ilişkin raporlarıdır. BMIHHEB'nin 26. maddesinde eğitim hakkı düzenlenmektedir ${ }^{12}$. BMESKHS'nin eğitim hakkını düzenleyen 13. $\operatorname{maddesinin}^{13}$ de bu düzenlemeye paralel olduğunu görmekteyiz. BMESKHS'nin eğitim hakkını düzenleme biçiminde dikkati çeken ilköğretimin zorunlu ve parasız olması gerektĭgi; ortaöğretimin çeşitlendirilmesi, mesleki ve teknik eğitime yer verilmesi ve bunların açık ve erişilebilir olması gerektiği; yükseköğretimin herkese açık, erişilebilir, kişisel yetenekler temelinde düzenlenmiş ve tedricen parasız olarak yaygınlaştırılması gerektiği; yeterli bir burs sisteminin kurulması gerekliliği; eğitim personelinin maddi koşullarının sürekli olarak iyileştirilmesi gerektiği hususlarıdır. Bununla birlikte maddede dikkati çeken diğer bir husus da eğitimin diğer bütün hakların gerçekleşmesi ve barışç1 bir dünya düzeni için öncelikle sağlanması gereken bir hak olduğudur. Türkiye, eğitim hakkını düzenleyen 13. maddenin 4. ve 5. paragraflarına çekince koyarak, bunların Anayasanın 3., 14. ve 42. maddeleri çerçevesinde yorumlama hakkının saklı olduğunu beyan etmiştir. Bu paragraflar ailelerin çocuklarına kendi inançlarına uygun dini ve ahlaki eğitim verme hakkı ile birey ve kuruluşların eğitim

\footnotetext{
UN General Assembly, Universal Declaration of Human Rights, 10 December 1948, General Assembly Resolution 217 A (III). Beyanname'nin -aslında Resmi Gazete'de yayımlanması olağan olan hukuki metinlerden olmamasına rağmen- önemine istinaden Resmi Gazete'de yayımlanmasına 6 Nisan 1949 tarih ve 9119 sayılı Bakanlar Kurulu kararı ile karar verilmiştir. Ardından Beyanname'nin resmi Türkçe çevirisi 27 Mayıs 1949 tarih ve 7217 sayılı Resmi Gazete'de yayımlanmıştır. Rona Aybay, Açıklamalı İnsan Hakları Evrensel Bildirisi, (Türkiye Barolar Birliği Yayınları, 2006), 8. RG 27.05.1949 - 7217.

9 UN General Assembly, International Covenant on Economic, Social and Cultural Rights, 16 December 1966, General Assembly Resolution 2200A (XXI), United Nations, Treaty Series, vol. 993, p. 3.

19 Aralık 1966 tarihinde imzaya açılan Sözleşme, 3 Ocak 1976 tarihinde yürürlüğe girmiştir. <https://www.refworld.org/ docid/3ae6b36c0.html > erişim tarihi 12 Ağustos 2020.

Türkiye ise Sözleşme'yi 15 Ağustos 2000 tarihinde imzalamış, 4 Haziran 2003 tarih ve 4867 sayılı Kanunla uygun bulunmuş ve Bakanlar Kurulunun 10 Temmuz 2003 tarih ve 2003/5923 sayılı kararıyla onaylamıştır. Sözleşme, Türkiye bakımından BM Genel Sekreterliğine tevdi edildikten sonra, 23 Aralık 2003 tarihinde yürürlüğe girmiştir. Sözleşme'nin resmi Türkçe çevirisi için bkz RG 11.08.2003 - 25196.

10 UN General Assembly, Convention on the Rights of the Child, 20 November 1989, General Assembly Resolution 44/25, United Nations, Treaty Series, vol. 1577, p. 3.

Kabul edildiği tarihte imzaya açılan Sözleşme, 2 Eylül 1990 tarihinde yürürlüğe girmiştir. <https://www.refworld.org/ docid/3ae6b38fo.html> erişim tarihi 12 Ağustos 2020.

Türkiye ise Sözleşme'yi, 14 Eylül 1990 tarihinde imzalamıştır. Sözleşme'nin 9 Aralık 1994 tarih ve 4058 sayılı Kanunla onaylanması uygun bulunmuştur. RG 11.12.1994-22138.

Sözleşme, Türkiye bakımından BM Genel Sekreterliğine tevdi edildikten sonra, 23 Aralık 2003 tarihinde yürürlüğe girmiştir. Sözleşme'nin resmi Türkçe çevirisi için bkz RG 27.01.1995 - 22184.

11 Aralık 1994 tarih ve 22138 sayılı Resmi Gazete'de yayımlanmıştır. Sözleşme'nin onaylanmasına ilişsin 23 Aralık 1994 tarih ve 94/6423 sayılı Bakanlar Kurulu Kararı ve Sözleşme'nin resmi Türkçe çevirisi, 27 Ocak 1995 tarih ve 22184 sayılı Resmi Gazete'de yayımlanmıştır. Onay belgeleri 4 Nisan 1995 tarihinde Birleşmiş Milletler Genel Sekreterliğine tevdi edilmiş ve Sözleşme, Türkiye bakımından 4 Mayıs 1995 tarihinde yürürlüğe girmiştir.

11 BM İnsan Hakları Konseyi eğitim hakkı özel raportörünün bugüne kadarki bütün raporlarının listesi için bkz <https:// ap.ohchr.org/documents/dpage_e.aspx?m=999> erişim tarihi 08 Mayıs 2020.

12 Madde metni için bkz Ek 1.

13 Madde metni için bkz Ek-2.
} 
kurumu kurma ve yönetme özgürlüklerine ilişkindir ${ }^{14}$. Öte yandan Türkiye, -aslında çok sayıda devlet gibi- BMESKHS'nin, bireysel şikâyet ve soruşturma usulünü ${ }^{15}$ öngören ek protokolü de imzalamamıştır.

Birleşmiş Milletler'in Çocuk Hakları Sözleşmesi (BMÇHS) ise, çocuklarla ilgili her alanda, günümüzde ulusal yargı yerlerinin de güncel kararlarında sıklıkla atıf yaptığı "çocuğun en yüksek yararı" ilkesini düzenlemekte ve çocuğun eğitimi konusuna bu açıdan yaklaşmaktadır. Hukukta çocuk 18 yaşını doldurmamış kişilerdir. $\mathrm{Bu}$ açıdan ilke olarak yükseköğretim sistemi öncesindeki ilk, orta ve lise öğretimine ilişkin düzenlemeler çocuk haklarını da yakından ilgilendirmektedir. BMÇHS'nin 24. maddesi çocuğun sağlık hakkına ilişkindir ${ }^{16} ; 28$. ve 29 . maddeleri de çocuğun eğitim hakkına ${ }^{17}$ ilişkindir. Özellikle 28. ve 29. maddelerde dikkati çeken husus ise, eğitimin firsat eşitliği temelinde ve çocuğun en yüksek yararı gözetilerek düzenleneceğidir. Türkiye BMÇHS'nin 17., 29 ve 30. maddelerini Anayasa ile 24 Temmuz 1923 tarihli Lozan Anlaşması hükümlerine ve ruhuna uygun olarak yorumlama hakkını saklı tuttuğunu beyan etmiştir. Türkiye öte yandan BMÇHS'nin denetim organı olan Çocuk Hakları Komitesine bireysel şikâyet usulünü düzenleyen 2014 tarihli ihtiyari protokolü de imzalamış ve onaylamıştır; ancak Türkiye hakkında herhangi bir başvuru henüz söz konusu değildir ${ }^{18}$.

\section{A. Ekonomik, Sosyal, Kültürel Haklar Komitesi ile Çocuk Hakları Komitesinin Önemli Genel Yorumları}

Birleşmiş Milletler Ekonomik, Sosyal ve Kültürel Haklar Sözleşmesi'nin denetim organı olan Ekonomik, Sosyal ve Kültürel Hakları Komitesinin, eğitim hakkını düzenleyen 13. maddeye ilişkin 13 No.lu Genel Yorumunda ${ }^{19}$ eğitim hakkının norm

\footnotetext{
14 Çalışmada eğitim hakkına ilişkin söz konusu hususlar ve tartışmalar, doğrudan salgın hastalık nedeniyle ortaya çıkabilecek eğitim hakkı ihlallerine yönelik olmadığı için kapsam dışı bırakılmıştır. Ancak elbette eğitim hakkına ilişkin aile-çocukdevlet ilişkisindeki tartışmalar da esaslı meselelerdir ve hakkın kapsamı açısından belirleyicidir. Bu açıdan eğitim özgürlüğü, bedensel cezalandırma yasağı, eğitimde her türlü (etnik, kültürel, sosyal sınıf ya da statü, cinsel, engele dayalı, yaş vb.) ayrımcılığın önlenmesi, toplumsal cinsiyet eşitliği ve eğitimde çalışanların hakları gibi eğitim hakkının norm alanını oluşturan hususlar çok yönlü irdelenmemiş; yalnızca salgın hastalık nedeniyle eğitim-öğretim alanında ortaya çıkabilecek güncel somut sorunların eğitim hakkı bakımından bir tahlili yapılmıştır.

15 Özellikle ağır veya sistematik insan hakları ihlalleri açısından önemli bir anlamı olan soruşturma usulünün, ana hatları ile Avrupa İnsan Hakları Sözleşmesi'ndeki bireysel başvuru usulüne benzeyen bireysel şikâyet usulüne nazaran, insan haklarının korunması bakımından daha etkin yönleri bulunmaktadır. Bu yönler için bkz Gülay Arslan Öncü, 'Ulusalüstü İnsan Hakları Hukukunda Soruşturma Usulü’ (2011) 31 Milletlerarası Hukuk ve Milletlerarası Özel Hukuk Bülteni 85, 87.

16 Madde metni için bkz Ek-3.

17 Madde metni için bkz Ek-4.

18 UN Human Rights Council, Optional Protocol to the Convention on the Rights of the Child on a Communications Procedure: resolution / adopted by the Human Rights Council, 14 July 2011, A/HRC/RES/17/18, <https://www.refworld. org/docid/4e72fbb12.html> erişim tarihi 14 Ağustos 2020.

Çocuk Haklarına Dair Sözleşmenin Başvuru Usulüne İlişkin İhtiyari Protokol, 14 Nisan 2014 tarihinde yürürlüğe girmiştir. Türkiye, 24 Eylül 2012 tarihinde ilgili Protokol'ü imzalamış ve 9 Mart 2017 tarih ve 6976 sayılı Kanun'la onaylamayı uygun bulmuştur. RG 30027/3 Nisan 2017. Ardından 11 Eylül 2017 tarih ve 2017/10836 sayılı Bakanlar Kurulu kararıyla Protokol'ün onaylanması kabul edilmiştir. Bu karar ve Protokol'ün resmi Türkçe çevirisi için bkz RG 7.12.2017-30263. Protokol, 26 Mart 2018 tarihinde Türkiye bakımından yürürlüğe girmiştir.

19 CESCR 'General Comment No. 13: The Right to Education (Art. 13 of the Covenant)', 8 December 1999, E/C.12/1999/10.
} 
alanı Sözleşme açısından belirlenmiştir. Buna göre eğitim hakkı, hem kendisi bir haktır, hem de diğer tüm hakların gerçekleşebilmesi için vazgeçilmez bir araçtır. Komitenin Genel Yorumunda eğitim, özellikle sosyal ve ekonomik açıdan elverişsiz durumda olan yetişkin ve çocukların kendilerine hayatta bir firsat yaratabilmelerinin ve yoksulluktan kurtulabilmelerinin yegâne aracı olarak tanımlanmaktadır. Bununla birlikte eğitim, demokratik bir düzenin hayata geçirilmesinde, kadınların ve çocukların istismara uğramasının önlenmesinde de hayati bir öneme sahiptir. Devletler açısından en iyi ekonomik yatırım olan eğitim aynı zamanda birey açısından da insansal olanaklarını geliştirebildiği bir etkinliktir ${ }^{20}$. Sözleşme'nin 13. maddesine göre eğitim, BM'nin temel ilkeleri ile uyumlu olarak, bireylerin, özgür bir topluma etkili katılımlarına olanak sağlamalı ve insanların onur ve haklar bakımından eşit oldukları anlayışı ile biçimlenmelidir; bu husus ilgili maddede eğitimin amacı olarak belirlenmiştir. Bir başka ifade ile eğitim hakkı her şeyden önce böylesine bir içeriğe sahip eğitime yönelik bir talep etme yetkisi ortaya çıkartmaktadır ve güncel uluslararası hukukta eğitim hakkından değil nitelikli eğitim hakkından söz edilmektedir. Ardından 13. madde, bir eğitim alma hakkını (13/2), ilköğretim alma hakkını (13/2-a), orta öğretim alma hakkını (13/2-b), teknik ve mesleki eğitim alma hakkını (13/2-b), yükseköğretim hakkını (13/2-c), ilköğretimini tamamlayamamış herkes için bir temel eğitim hakkını (13/2-d) ve etkili bir okul sistemi, yeterli bir burs sistemi ile eğitim-öğretim personelinin iyi maddi koşullara sahip olma hakkını (13/2e) düzenlemekte ve tüm bu hususlar eğitim hakkı kapsamında değerlendirilmektedir. Devletlerin ekonomik ve sosyal koşullarının çeşitli olabileceği göz önünde bulundurulmakla birlikte, tüm bu hakların ve devlet sorumluluklarının kapsamını belirlemek açısından ise dört ölçüt ortaya konulmuştur. Bu ölçütler mevcudiyet, erişilebilirlik, kabul edilebilirlik ve uyum sağlayabilmedir ${ }^{21}$. Genel Yoruma göre; mevcudiyet, taraf devletteki eğitim kurumlarının ve eğitim programlarının yeterli sayıda ve etkin olması anlamına gelmektedir. $\mathrm{Bu}$ açıdan bir eğitim kurumunun yalnızca binasının olması yeterli olmamakta; binaların eğitime elverişli, işlevsel, iki cinsiyet için de eşit sıhhi tesisatı ve temiz içme suyu olan, kütüphane, çeşitli araçgereçler, eğitim materyali, bilgisayar ve diğer ihtiyaç duyulan teknolojik alete sahip yapıda olmaları gerekmektedir. Elbette mevcudiyet koşulu kapsamında yalnızca binalar değil, eğitim personelinin de makul ücretten çalışıyor olmaları hakkın kapsamında değerlendirilmektedir. Bu doğrultuda öğretmenlerin çalışma koşulları ve ücretleri ile ilgili olumsuz durumlar, öğrenciler açısından bir eğitim hakkı ihlali gündeme getirecektir. Erişilebilirlik, eğitim kurumunun ve programlarının taraf devletin yargı yetkisi içinde olan herkes için erişilebilir olması anlamına gelmektedir. Erişilebilirliğin üç alanı bulunmaktadır. Bunlardan ilki, eğitim kurumunun makul bir coğrafi konumda bulunması gibi güvenli fiziksel erişilebilirliktir. Uzaktan

\footnotetext{
ibid para 1.

21 ibid para 6.
} 
eğitim verilmesi söz konusu ise, uzaktan eğitime modern teknoloji yoluyla erişim de fiziksel erişilebilirliğin kapsamında değerlendirilmektedir. Örneğin bu açıdan COVID-19 salgını nedeniyle uzaktan eğitime erişim engeli olan öğrenciler açısından eğitim hakkının ihlalini ortaya çıkartacak durumlar söz konusu olabilir. İkincisi ekonomik erişilebilirliktir. Eğitimin herkes için maddi açıdan karşılanabilir olması gerekmektedir. Bu açıdan yüksek okul ücretleri yine eğitim hakkının ihlalini ortaya çıkartacaktır. Üçüncüsü ise eğitimin ayrımcılık gözetmeden, hem yasal olarak hem de fiilen herkes ve özellikle savunmasız gruplar için erişilebilir olmasıdır. Kabul edilebilirlik, eğitimin biçiminin ve içeriğinin, müfredatın ve öğretim metotlarının ebeveynler tarafından (nitelikli, kaliteli ve kültürel açıdan uygun nitelikte olması) kabul edilebilir olmasıdır. Bu açıdan eğitim, 13. maddenin ilk paragrafında belirlenen temel amaçlara yönelmiş olmalıdır. Uyarlanırlık ise, eğitimin değişen toplumsal ihtiyaçlara ve öğrencilerin ihtiyaçlarına yanıt verebilmek için esnek olması anlamına gelmektedir. Bütün bu ölçütler ise, "öğrencilerin en yüksek yararı" ilkesi temelinde uygulanmalıdır ${ }^{22}$. Devletlerin eğitim hakkı ihlalleri ise icrai (fiiller ile) olabileceği gibi ihmali de (alması gereken tedbirleri almamasından kaynaklı) olabilir. Elbette Genel Yorumda devletlerin mali kaynaklarının yeterliliği ölçüsünde eğitime ilişkin belli hususların hayata geçirilmesinin dikkate alındığı yer almakla birlikte, devletlerin derhal yapabileceği, örneğin eğitimde her türlü ayrımcllı̆̆ önlemeye yönelik tedbirler de bulunmaktadır. Eğitim hakkının korunabilmesi için alınacak her türlü tedbirin ise, "kesin, somut ve hedef odaklı" olması gerekmektedir ${ }^{23}$. Eğitim hakkının geleceğe yönelik ya da giderek artan biçimde gerçekleştirilmesi (progressive realization), devletlerin 13. maddenin hayata geçirilmesi için, "mümkün olduğunca hızlı ve etkili bir şekilde ilerleme" biçiminde belirli ve sürekli bir sorumluluklarının olduğu anlamına gelmektedir ${ }^{24}$.

Ekonomik, Sosyal ve Kültürel Haklar Komitesinin en güncel 30 Nisan 2020 tarihli ve 25 No.lu Genel Yorumu da konumuz açısından önemlidir ${ }^{25}$. Bilimsel ilerleme ile ekonomik, sosyal, kültürel haklar arasındaki ilişkiye değinen Genel Yorum, özellikle bilimsel ve teknolojik gelişmelerin, sağlik, eğitim ve gıda haklarına olan etkisinden söz etmekte ve devletlerin bilimsel ve teknolojik gelişmelerden toplumun eşit yararlanmasına özen göstermesi gerektiğini belirtmektedir. Devletler, fikri mülkiyet ve patent düzenlemelerini, insanların eğitim, sağlık ve gıda hakkı ile denge kurarak gerçekleştirmelidir ${ }^{26}$. Örneğin bu açıdan, eğitim hakkı kapsamında, eğitim materyali ve gerekli teknolojiye erişimin herkes için eşit olarak sağlanması, makul bir ücretten sunulması, kişilerin fikri mülkiyet ve patent haklarının korunması kadar, toplumun

\footnotetext{
ibid para 6 .

ibid para 43.

4 ibid para 44.

25 CESCR 'General Comment No. 25 on science and economic, social and cultural rights (article 15 (1) (b), (2), (3) and (4) of the International Covenant on Economic, Social and Cultural Rights' 30 April 2020, E/C.12/GC/25.

26 ibid para 62.
} 
bu bilimsel buluş, eser ve teknolojik gelişmelerden adil bir biçimde yararlanmasının sağlanması da önem arz etmektedir. Devletler bu hususlara dikkat ederek, fikri mülkiyet ve patent hukuku ile eğitim hakk1 arasında bir denge gözetmelidir ${ }^{27}$. Bu açıdan Türkiye'de COVID-19 salgını süresince çeşitli ulusal ve uluslararası veri tabanlarının, çevirim içi kitap ve ders materyalinin öğrencilere ücretsiz olarak erişime açılmış olması önemli bir uygulamadır ${ }^{28}$.

Çocuk Hakları Komitesi, COVID-19 salgını nedeniyle Çocuk Hakları Sözleşmesi'ne taraf devletlerin göz önünde bulundurması gereken önemli hususlara dikkati çekmiştir. Komitenin 8 Nisan 2020 tarihli açıklamasında devletlerin özellikle, uzaktan ya da çevirim içi eğitimin, var olan eşitsizliklerin daha da derinleşmesine yol açmamasını ve öğrenci-öğretmen etkileşiminin yerini almamasını garanti etmeleri gerektiği belirtilmiştir. Özellikle, ebeveyn desteği görmeyen ya da göremeyen ve internet ile teknolojiye erişimi olmayan çocuklar için, öğretmen desteğinden yararlanabilecekleri alternatif çözümler üretilmelidir ${ }^{29}$. Yine aynı belgede, hijyen standartları ve sosyal mesafe kurallarına uymak kaydı ile çocukların günde hiç olmazsa bir defa açık havada kontrollü bir biçimde aktivite yapabilmelerine olanak tanınması ve televizyon vb. basın yayın araçlarında çocuk-dostu kültürel-sanatsal aktivitelere yer verilmesinden söz edilmektedir ${ }^{30}$. Çocuklar ile ilgili alınacak tedbirlerde onların da seslerinin duyulmasını ve ne olup bittiğini anlamalarını sağlayacak biçimde, karar alma süreçlerine katılımlarının ve çeşitli iletişim kanallarının sağlanması gerekmektedir $^{31}$. Almanya'da kimi eyaletlerde, çeşitli acil hizmetler ve sağlık alanında çalışanların çocuklarının bakımı için, çocuğun en yüksek yararı ilkesine atıfla çeşitli önlemler alınmıştır. Bunlar arasında gündüz bakım evlerinin ve kreşlerin çekirdek elemanları ile ve adı geçen alanlarda çalışan ebeveynlerin çocukları ile sinırlı olmak kaydıyla, az sayıda (en fazla 10'a kadar değişebilen) çocuğa hizmet vermesi düzenlenmiştir ${ }^{32}$.

ibid para 62. Özellikle yeni teknolojilerin ortaya çıkardığı tehlikelere ilişkin açıklamalar için bkz ibid paras 72-76. Bu açıdan örneğin üniversite kitaplarının pahalı olması sorunu sıklıkla dile getirilmektedir. Üniversiteler ders kitabı olarak okutulacak kitaplar listesini öğretim üyelerinden sene başında talep ederek, aynı kitaptan çok sayıda üniversite ya da ilgili fakülte / bölüm kütüphanesine satın alabilir ve bunları herkes için erişilebilir kılabilir.

28 Örnek olarak "YÖK Dersleri Platformu" incelenebilir. <https://yokdersleri.yok.gov.tr/> erişim tarihi 8 Mayıs 2020.

29 CRC 'The Committee on the Rights of the Child warns of the grave physical, emotional and psychological effect of the COVID-19 pandemic on children and calls on States to protect the rights of children' 8 April 2020, para $3<\mathrm{https}$ ://tbinternet. ohchr.org/Treaties/CRC/Shared\%20Documents/1_Global/INT_CRC_STA_9095_E.pdf> erişim tarihi 08 Mayıs 2020.

30 ibid para 2.

31 ibid para 11

32 Tina Groll, 'Wer darf sein Kind in die Kita schicken?' (Zeit Online, 17 April 2020) <https://www.zeit.de/politik/ deutschland/2020-04/corona-notbetreuung-franziska-giffey-kita-faq > erişim tarihi 18 Mayıs 2020. Çeşitli eyaletlerde "Yuva ve Kreşlerde Acil Bakım Gerekliliği-Ebeveynlerin Açıklaması" isimli belgelerle başvuru yapan ve belli alanlarda çalışan ebeveynler için kreş hizmeti sunulmaktadır. 


\section{B. COVID-19 Salgını Süresince Kadınlar ve Çalışan Ebeveynler}

17 Nisan 2020 tarihinde BM Ekonomik, Sosyal ve Kültürel Haklar Komitesi eğitim hakkı açısından dikkat edilmesi gereken hususlara yer veren bir açıklama yayımlamışıır ${ }^{33}$. Buna göre, salgın nedeniyle eğitime uzaktan devam edilmesi, eğitim kurumlarının kapanmasının, eğitim hakkına yönelik oluşturduğu müdahalenin etkilerini azaltmaya yönelik bir önlemdir. Ancak uzaktan eğitim, internet servislerine, bilgisayarlara, tablet vb. diğer gerekli donanıma erişim açısından yoksul ve zenginler arasındaki eşitsizlikleri derinleştirme tehlikesi barındırmaktadır ${ }^{34}$. Bunun yanı sıra Komite, COVID-19 salgınının, kadın-erkek eşitsizliğini derinleştirdiğini ve çocuk bakımı konusunda halen birçok toplumda geçerli olan yaygın anlayışın, salgın süresince kadınlar aleyhine sonuç doğurduğunu ve ev içi şiddet tehlikesinin ve vakalarının arttığını belirtmektedir ${ }^{35}$. Bu açıdan devletlerin internet ve teknolojiye erişim ile cinsiyet temelli eşitsizlikten kaynaklanacak hak ihlallerinin önüne geçecek tedbirleri alması gerekmektedir ${ }^{36}$. Ayrıca BM Kadınlara Karşı Her Türlü Ayrımcılığın Önlenmesi Sözleşmesi'nin ${ }^{37}$ (BMKKAÖKS) eğitim hakkı başlıklı 10. maddesi de kadınların eğitim alanında erkeklerle eşit haklara ve koşullara sahip olması gerektiğini ve özellikle kariyer rehberliği verilmesini düzenlemektedir. Sözleşme'nin 11. maddesi de çalışma hakkına ilişkin ayrımcılık yasağını düzenler. Bununla birlikte Kadınlara Karşı Her Türlü Ayrımcılığın Ortadan Kaldırılması Komitesi de (CEDAW) COVID-19 salgını nedeniyle alınacak tedbirlerde, kadınlara özel durumların dikkate alınmasının ve karar verici aşamalarda ve salgınla mücadele politikalarında kadınların eşit katılımının garanti altına alınmasının önemini vurgulamaktadır ${ }^{38}$. CEDAW aynı zamanda bu süreçte ev içi şiddet olaylarının arttığını ve devletlerin buna karşı önlem alması gerektiğini belirtmektedir ${ }^{39}$. BM İnsan Hakları Yüksek Komiserliğinin "COVID-19 ve Kadınların İnsan Hakları" başlıklı raporunda çeşitli

\footnotetext{
3 CESCR 'Statement on the coronavirus disease (COVID-19) pandemic and economic, social and cultural rights Statement by the Committee on Economic, Social and Cultural Rights' 17 April 2020 E/C.12/2020/1.

34 ibid para 7.

35 ibid para 8.

36 Avrupa Cinsiyet Eșitliği Enstitüsü’nün “COVID-19 ve Cinsiyet Eșitliği”’ bașlıklı çalıșması da incelenebilir. "Covid-19 and Gender Equality’ European Institute on Gender Equality <https:/eige.europa.eu/topics/health/covid-19-and-genderequality> erişim tarihi 9 Mayıs 2020. Benzer şekilde Inside HigherED araştırmasına göre COVID-19 özellikle kadın akademisyenlerin yayın, araştırma ve üretkenliğini ciddi biçimde olumsuz etkilemektedir. Colleen Flaherty, 'No Room of One's Own', (Inside HigherED, 21 April 2020) < https://www.insidehighered.com/news/2020/04/21/early-journalsubmission-data-suggest-covid-19-tanking-womens-research-productivity> erișim tarih 9 Mayıs 2020. Aynı șekilde bkz Colleen Flaherty, 'Faculty Home Work', (Inside HigherED, 24 March 2020) <https://www.insidehighered.com/ news/2020/03/24/working-home-during-covid-19-proves-challenging-faculty-members> erişim tarihi 9 Mayıs 2020.

37 UN General Assembly, Convention on the Elimination of All Forms of Discrimination Against Women, 18 December 1979, United Nations, Treaty Series, vol. 1249, p. 13, General Assembly Resolution 34/180 of 18 December $1979<\mathrm{https}$ ://www. refworld.org/docid/3ae6b3970.html> erişim tarihi 14 Ağustos 2020.

Kadınlara Karșı Her Türlü Ayrımcılığın Önlenmesi Sözleşmesi 3 Eylül 1981 tarihinde yürürlüğe girmiştir. Türkiye'de, 11 Haziran 1985 tarih ve 3232 sayılı Kanun ile Sözleşme’nin onaylanması uygun bulunmuştur. RG 25.06.1985-18792. Ardından 24 Temmuz 1985 tarih ve 85/9722 sayılı Bakanlar Kurulu kararı ile onaylanmıș ve resmi çevirisi Resmi Gazete'de yayımlanmıştır. RG 14.10.1985-18898. Sözleşme Türkiye bakımından 19 Ocak 1986 tarihinde yürürlüğe girmiştir.

38 CEDAW, 'Guidance Note on CEDAW and COVID-19' $2<$ https://www.ohchr.org/en/hrbodies/cedaw/pages/cedawindex. aspx> erişim tarihi 19 Mayıs 2020.

39 ibid.
} 
ülkelerin özellikle şiddet vakalarının artması karşısında verdikleri sosyal hizmetleri arttırdığ 1 ve ek önlemler aldığı belirtilmektedir. Çeşitli ülkeler bu süreçte kadınların sağlığı ile ilgili telefonla uzaktan hizmet ve bilgilendirme sunmaktadır. Söz konusu raporda bunlara ek olarak CEDAW raporuna benzer endişelere de yer verilmektedir ${ }^{40}$. UNESCO'ya göre dünya genelinde okulların kapanması en çok kız çocuklarını olumsuz yönde etkileyecektir. Buna göre hâlihazırda dünyadaki okula giden nüfusun \%89'u şu anda okul dışındadır. Bu oranın yaklaşık yarısı (743 milyonu) kız öğrencilerden oluşmaktadır ve bunların da 111 milyonu eğitime erişimin önceden de problemli olduğu az gelişmiş ülkelerde yaşamaktadır ${ }^{41}$. Önceki yıllarda meydana gelen ebola ve zika salgınlarında en elverişsiz olanların kadınlar ve kız çocukları olduğu, salgın nedeniyle okulların kapatıldığı sürede ergen hamileliklerinin, çocuk evliliklerinin ve şiddet vakalarının ciddi oranda artış gösterdiği belirtilmektedir ${ }^{42}$.

OECD, COVID-19 salgınının etkileri üzerine gerçekleştirdiği araştırmasında kadınların en elverişsiz grup olduğunu ve devletlerin salgın karşısında aldıkları tedbirlerin ani ve acele olarak (immediate) kadınların sorunlarına yönelik olması gerekliliğini vurgulamaktadır ${ }^{43}$.

Neler Yapılabilir? Devlet, eğitime ara verilen salgın döneminde, kız çocuklarının okul ve eğitimden uzaklaş(tırıl)maması için gerekli önlemleri öncelikle almaya dikkat etmelidir. Bununla birlikte özellikle çocuklu ailelere yönelik, iş ve çocuk bakımı

40 OHCHR, 'Covid-19 and Women's Human Rights: Guidance'(OHCHR, 15 April 2020) <https://www.ohchr.org/Documents/ Issues/Women/COVID-19_and_Womens_Human_Rights.pdf> erişim tarihi 19 Mayıs 2020.

41 Stefania Giannini, 'Covid-19 school closures around the world will hit girls hardest' (UNESCO, 31 March 2020) <https:// en.unesco.org/news/covid-19-school-closures-around-world-will-hit-girls-hardest> erişim tarihi 19.05.2020.

42 Sara E. Davies/Belinda Bennett, 'A gendered human rights analysis of Ebola and Zika: locating gender in global health emergencies' (2016) 92(5) International Affairs 1045, 1048.

Yazarlar ebola, zika gibi hastalıkların "karmaşık tehlikeli durum (complex emergencies)" olduğunu ve karmaşık tehlikeli durumlardan en olumsuz etkilenen grubun daima kadınlar ve kız çocukları olduğunu belirtmektedirler.

43 OECD 'Women at the core of the fight against COVID-19 crisis'<https:/www.oecd.org/coronavirus/policy-responses/ women-at-the-core-of-the-fight-against-covid-19-crisis/> erişim tarihi tarih 9 Mayıs 2020. OECD'nin önerileri arasında, özellikle sağlık alanında, kamusal kurumlarda ve acil hizmetlerde çalışan ebeveynlere yönelik çocuk bakım hizmeti sağlanması; işten ayrılmak zorunda kalan çalışanlara mali destek sağlanması, çalışanlarına ücretli izin veren işletmelere mali destek sağlanması, çalışanların ailevi sorumluluklarını yerine getirebilmeleri için esnek çalışma düzenlemeleri yapılması bulunmaktadır. OECD araştırmasına göre, “...ebeveynlerin okul kapanma durumunda izin almalarına ilişkin ek hakları genellikle belirsizdir. Hemen hemen tüm OECD ülkeleri, çalı̧̧anlara bakmakla yükümlü oldukları kişilere bakmak için işten ayrılma olanağı tanımaktadır. Bazı ülkelerde, "öngörülemeyen acil durumlar" (örneğin Avustralya, Birleşik Krallık, Polonya ve Slovak Cumhuriyeti) okulların beklenmeyen şekilde kapanmasını da içermektedir ve çalışan ebeveynlerin işten ayrılma hakları bulunmaktadır. Bazı ülkelerde, (örneğin Avusturya ve Almanya) okul veya çocuk bakım tesislerinin kapatılması durumunda "acil izin haklarının" uygulanacağını açıklamıştır. Ancak kimi durumlarda da süresiz ücretsiz hakkı söz konusu olmaktadır. Birçok ebeveynin, ücretsiz izin almaya gücü yetmeyebilir. Ayrıca, bazı ülkelerde (örneğin Avusturya, Almanya ve Slovak Cumhuriyeti), bu ücretli izinler açısından süre sınırı bulunmaktadır; bazılarında da süre sınırı belirsizdir. Bazı ülkeler okulların veya çocuk bakım merkezlerinin kapatılması durumunda çalışan ebeveynlere yardımcı olmak için acil durum önlemleri uygulamaya başlamışlardır. Çocuk bakım tesislerinin ve okullarının kapatıldı̆̆ birçok ülkede (örneğin Avusturya, Fransa, Almanya ve Hollanda), özellikle sağllk ve sosyal bakım ve ögretimde temel hizmet çalı̧̧anlarının çocuklarına bakmak için çekirdek personel ile bazı tesisler açık kalmaktadır. Örneğin, Fransa'da, bu tür aileler için çocuk bakım tesisleri en fazla 10 çocuk barındırabilir ve evlerinden çalışan çocuk bakıcıları istisnai olarak 3 çocuk yerine 6 çocuk alabilirler. Kamu sektöründe, bazı ülkeler ebeveynlerin iş ve bakımı dengelemelerine yardımcı olmak için esnek çalıșma seçeneklerini de genişletmektedir. Örneğin Irlanda, kamu işleri çalışanları için uzaktan çalı̧̧ma, esnek vardiyalar, kademeli vardiyalar, daha uzun çalışma saatleri ve hafta sonu çalışmaları dahil olmak üzere bir dizi esnek çalışma firsatı sunmuştur. Yenilikçi bir uygulama, kritik hizmetlerin sunulmasına izin verirken esnek çalışma seçeneklerini etkili bir şekilde kolaylaştırmak için çalışanların geçici olarak farklı rollerde veya kuruluşlarda çalışmasını gerektirmektedir." 
arasındaki dengeyi gözetecek düzenlemelerin yapılması gerekmektedir. $\mathrm{Bu}$ açıdan önümüzdeki yıllarda çocuklu akademik aileler ya da ebeveynlerin (ya da performansa dayalı ücret elde edilen işlerde çalışanların) çocuksuz olanlara oranla daha düşük bir performans sergilemiş ${ }^{44}$ olması olası görünmektedir. Dolayısıyla, COVID-19 salgını nedeniyle yaşanan 6 aylık, 1 yıllık ya da salgının seyrine göre uygun bir sürenin, atama ve yükseltme ölçütleri değerlendirilirken - özellikle de kadınların konumu dikkate alınarak- düşülmesi gerekebilecektirr ${ }^{45}$.

\section{Uluslararası Hukukta Eğitim Hakkından "Nitelikli Eğitim” Hakkına Doğru Gelişim}

Eğitim hakkı ile ilgili uluslararası hukukta bir diğer güncel mesele eğitim hakkının yalnızca eğitime erişim ve okullarla ilgili düzenlemeleri değil, aynı zamanda eğitimin içeriğine ilişkin de bir talep hakkı ortaya çıkarttığı yönündedir. Bu husus yukarıda söz edilen Ekonomik, Sosyal, Kültürel Haklar Komitesinin 13 No.lu Genel Yorumunda belirlenen "kabul edilebilir olma ve uyarlanabilirlik" ölçütleri ile ifade edilmektedir. COVID-19 salgını süresince okuldan uzak kalan öğrencilerin nitelikli eğitim alabilmeleri için dünya genelinde çeşitli projeler ve çözüm önerileri sunulmuştur ${ }^{46}$.

Nitelikli eğitim hakkı açısından, COVID-19 salgını nedeniyle okulların 2019-2020 eğitim-öğretim yıllarının bahar yarıyılı başarı değerlendirme ölçütleri ve okullardaki derslerin devamına ilişkin konular tartışılabilir. Ülkemizde salgın nedeniyle Millî Eğitim Bakanlığı Okul Öncesi Eğitim ve İlköğretim Kurumları YönetmeliğiOÖİEKY ${ }^{47}$ ve Millî Eğitim Bakanlığı Ortaöğretim Kurumları Yönetmeliği-OKY ${ }^{48}$ bazı hükümleri değiştirilerek, zorunlu tedbir olan uzaktan eğitimde ve bunlara ilişkin

\footnotetext{
${ }_{4}$ Arianne Cohen, 'Women's academic journal submissions plummet amid coronavirus' (Fast Company, 1 May 2020) $<$ https://www.fastcompany.com/90499954/womens-academic-journal-submissions-plummet-amid-coronavirus> erişim tarihi 9 Mayss 2020.

45 Bu olguya dikkat çeken bir tartışma ve öneriler için bkz Titan Alon/Matthias Doepke/Jan Olmstead-Rumsey/Michèle Tertilt, 'The Impact of COVID-19 on Gender Equality' (2020) 4 Covid Economics: Vetted and Real-Time Papers 81. Çalışmada Çalışmada 14 yaşından küçük çocukları olan ebeveynlerin atama ve yükseltme sürecindeki süre hesaplamalarının, COVID-19 salgını süresinin hesaba katılarak yapılması ve özellikle kadınların çocuk bakımında daha fazla zaman geçirmelerinin dikkate alınması önerilmektedir.

Öte yandan bir başka çalışmada da, cinsiyet ayrımı gözetmeksizin yapılan süre uzatımlarından yine erkeklerin kadınlara oranla daha avantajlı olduğu ve kadınların kadro elde etme, akademik atama ve yükseltmelerde süreler uzatılsa da, cinsiyetler arası farklılık dikkate alınmadığı için elverişsiz bir konumda bulunduğu belirtilmektedir. Bkz. Heather Antecol/Kelly Bedard/Jenna Stearns, 'Equal but inequitable: Who benefits from gender-neutral tenure clock stopping policies?' (2018) 108 American Economic Review, 2420-2441. Benzer şekilde, Amerikan Üniversite Profesörleri Derneği, "COVID-19 Karşısında Yükseköğretim İlkeleri” yayımlayarak üniversitelerin, COVID-19 kaynaklı bütün gecikme, vb. hususlarda çocuklu araştırmacılara uygun düzenlemeler yapmaları ve akademisyenlerin yeniden atamaları için işleyen kadro sürelerini durdurabilmeleri gerektiğine değinmektedir. 'Principles for Higher Education Response to COVID-19' (American Association of University Professors, 13 March 2020) <https://www.aft.org/sites/default/files/covid19_aftaaup_guidanceprinciples_031320.pdf> erişim tarihi 15 Mayıs 2020. Aynı derneğin "aile sorumlulukları ve akademik çalışma" raporu hakkında bkz < https://www.aaup.org/report/statement-principles-family-responsibilities-and-academicwork> erişim tarihi 9 Mayıs 2020. ABD'de birçok üniversite bu hususta kararlar almaktadır.

46 OECD'nin desteği ile hazırlanan rapor: 'Spotlight: Quality education for all during Covid-19 crisis' (HundrED ve OECD April 2020).

47 RG 26.07.2014-29072.

48 RG 07.09.2013-28758.
} 
telafi eğitiminde puanla değerlendirme yapılamayacağı (OÖEIKKY, md. 33/4 ve 5; OKY ek md. 2/5) düzenlenmektedir. Yine OÖEİKY'ye 8 Mayıs 2020 tarihinde eklenen ek madde 1'de: “...eğitim ve öğretime ara verilmesi ve sadece bir dönem puanının bulunması durumunda; bu puanin sinıf geçme puanının altında kalıp kalmamasına bakılmaksızın 4 üncü, 5 inci, $6 \mathrm{ncl}, 7 \mathrm{nci}$ ve 8 inci sinıflardaki tüm ögrenciler bir üst sınıfa geçmiş sayllır. Bu durumda derslerin bir döneme ait dönem puanlart yllsonu puanı olarak sayllır. Oluşan bu yılsonu puanı, ağırlıklı puan, yılsonu başarı puanı ve ortaokul başarı puanı (OBP) hesaplanmasında da kullanılır. Illkokul 1 inci, 2 nci ve 3 üncü sinıflarda eğitim ve öğretim faaliyetlerinin yapıldı̆̆ dönemde başarı durumu değerlendirilen ögrenciler bir üst sinıfa geçmiş sayllır. Ancak ilkokullarda velinin yazılı talebi doğrultusunda sinıf tekrar yaptırllabilir." hükmü yer almaktadır. Bu hususta incelenen Almanya'da eyaletler arasında bir yeknesaklık bulunmadığı görülmektedir. Kimi eyaletler bu dönemin sonunda Türkiye'dekine oldukça benzer biçimde sınıf tekrarının bu yıl ile sınırlı olmak kaydıyla hiçbir biçimde söz konusu olmayacağını ve puanlandırma yapılmayacağını düzenlerken; kimi eyaletler de uzaktan verilmiş olsa da bu dönemin sonunda elde edilen başarının yalnızca son sınıflar için söz konusu olabileceğini ya da okul açıldığında yapılacak sınıf ödevlerinin puanlanabileceği ve öğretmenler heyeti aracılı̆̆ıyla sınıf tekrarının söz konusu olabileceğini öngörmüştür49 Federal Devlet eyaletlerin okullarını 7 Mayıs 2020 tarihinden itibaren açabileceğini öngörmüş, kimi eyaletler sağlık ve hijyen kuralları doğrultusunda çeşitli düzenlemeler yaparak okulları açmıştır ${ }^{50}$. Bu gibi uygulamaların eğitimin niteliğine ilişkin tartışmaları beraberinde getireceği unutulmamalıdır. Bununla birlikte ilk dönem başarı notunun, ikinci dönem puanlandırılmayacağı için, bütün yıl notu olarak değerlendirmeye alınması hususu idari yargı önüne gelebilir. Bu husus başarı değerlendirmesinin ölçütlerine karar verme yetkisinin hukuki niteliği ile ilgilidir. Başarı değerlendirmesi ölçütlerinin idare tarafindan belirlenirken sahip olduğu takdir yetkisine yönelik hukuki tartışmalar, ilgili eğitim kurumunun niteliğine, başarı değerlendirmesi ölçütüne karar veren kişiye ve başarı değerlendirmesi araçlarına karar veren kişilere göre değişiklik göstermektedir ${ }^{51}$.

\section{Avrupa İnsan Hakları Sözleşmesi ve Mahkeme İçtihatlarında Ĕ̆itim Hakkı Meseleleri}

Türkiye'yi ilgilendiren bir diğer uluslararası sistem Avrupa bölgesinin insan hakları koruma sistemidir. Eğitim hakkı, Avrupa İnsan Hakları Sözleşmesi’ne Ek 1 No.lu

49 Eyaletlere ilişkin durum ve istatistik için bkz Miriam Olbrisch, 'So bewerten die Bundesländer das "Corona-Halbjahr"' (Spiegel Panorama, 12 May1s 2020) <https://www.spiegel.de/panorama/bildung/schulnoten-in-der-corona-krise-so-gehendie-bundeslaender-vor-a-8a3717a6-5f0f-469b-b50c-fa50186fd466> erişim tarihi 15 Mayıs 2020.

50 Örneğin NRW Eyaletinde okul sınıflarının haftanın her günü bir sınıf okula geçecek biçimde düzenlenmesini, öğrencilerin uzaktan eğitime devam ederken, hiç olmazsa haftanın bir günü okula gelerek öğretmenleri ile ders yapabilmelerini öngörmüştür. Bkz. NRW Eyaleti Eğitim Bakanlığı sayfası <https://www.schulministerium.nrw.de/docs/Recht/ Schulgesundheitsrecht/Infektionsschutz/300-Coronavirus/index.html> erişim tarihi 15 Mayıs 2020.

51 Turgut Tan, 'Sınav ve Jüri Değerlendirmelerinin Yargısal Denetimi' (1996) 51 Ankara Üniversitesi SBF Dergisi 410, 421. Başarı değerlendirmesi ve idarenin takdiri konusu Türk hukukundaki en tartışmalı alanlardan birisidir. 
Protokol'ün (EP-1) 2. maddesinde düzenlenmiştir ${ }^{52}$. Protokolde düzenlenen eğitim hakkının kapsamına ilişkin Avrupa İnsan Hakları Mahkemesi’nin yargı pratiği, daha çok negatif bir içerikte, eğitime erişimin kısıtlanması, ayrımcıllk ve ebeveynlerin çocuk üzerindeki haklarına yönelik tartışmalara ilişkindir. Elbette Avrupa İnsan Hakları Mahkemesi (AİHM), Sözleşme ve Ek Protokollerinde düzenlenen haklarla ilgili devletin pozitif yükümlülüklerini belli açılardan - özellikle ayrımcılık ile ilgili konularda- kabul etmekte ve bunu kararlarına da yansıtmaktadır ${ }^{53}$. Ancak eğitim hakkını düzenleyen EP-1'in hazırlık çalışmaları ve tartışmalar incelendiğinde pozitif yükümlülük doğuracak dilden kasıtlı olarak kaçınıldığ 1 görülmektedir ${ }^{54}$. Hazırlık çalışmalarında eğitim hakkı üzerinde yürütülen temel tartışma, -EP-1'in hazırlık tarihi de göz önünde bulundurulduğunda- eğitim sistemlerinde yer alabilen yoğun propaganda karşısında çocukları korumanın ebeveynlerin mi, yoksa devletin mi görevi olduğudur ${ }^{55}$. Bununla birlikte hazırlık çalışmaları sonunda nihai madde metni ${ }^{56}$ kaleme alınırken, devletin, herkesin kendi tercihleri doğrultusunda eğitim alabilmesi için etkili düzenlemeler yapma ya da özel eğitim kurumlarına gidebilmesi için finansal destek sağlama yükümlülüğünün olmadığı belirtilmektedir ${ }^{57}$. AİHM de, tüm bunlara ek olarak, Folgerø ve Diğerleri - Norveç davasında eğitim hakkını düzenleyen maddenin ikinci cümlesinin, AİHS'nin 9. maddesi (din ve vicdan

52 Council of Europe, Protocol 1 to the European Convention for the Protection of Human Rights and Fundamental Freedoms, 20 March 1952, ETS 9, <https://www.refworld.org/docid/3ae6b38317.html> ve <https://www.echr.coe.int/Pages/home. aspx?p=basictexts\&c=> erişim tarihi 13 Ağustos 2020.

Söz konusu Protokol 18 Mayıs 1954 tarihinde yürürlüğe girmiştir. Türkiye Ek 1 No.lu Protokolü 20 Mart 1952 tarihinde imzalamış ve 10 Mart 1954 tarihinde 6366 sayılı Kanun ile onaylamıştır. RG 19.03.1954 - 8662. Protokol Türkiye açısından 18 Mayıs 1954 tarihinde yürürlüğe girmiştir. Ancak Türkiye Protokol'ün eğitim hakkını düzenleyen 2. maddesine çekince koyarak, bu düzenlemenin Tevhid-i Tedrisat Kanunu'na aykırı olarak uygulanmayacağını belirtmiştir.

53 Abdullah Çelik, 'Avrupa İnsan Hakları Mahkemesi Kararlarında Eğitim Hakkı' (2015) 6 Türkiye Adalet Akademisi Dergisi 322.

54 'Prepatory Work on Article 2 of the Protocol to the Convention, Information Document prepared by the Registry of the Court' (Council of Europe, European Court of Human Rights, Strasbourg, 9 May 1967) CDH (67) 2.

$<$ https://www.echr.coe.int/LibraryDocs/Travaux/ECHRTravaux-P1-2-CDH(67)2-BIL2292567.pdf> erişim tarihi 12 Ağustos 2020. Özellikle "negatif yükümlülük" vurgusu için bkz ibid 198.

AİHS ve ek protokollerine ilişkin tüm hazırlık çalışmalarına (Travaux préparatoires) erişim için $<$ https://www.echr.coe.int/ Documents/Library_TravPrep_Table_ENG.pdf> erişim tarihi 14 Ağustos 2020.

55 ibid 11- 44, 47, 171-172.

56 Yaklaşık bir buçuk yıl süren Protokol'ün hazırlık çalışmalarında eğitim hakkına ilişkin madde dört farklı biçimde kaleme alınmıştır. Bunlar, Ağustos 1950-Danışma (Parlamenterler) Meclisi Taslağı, Ağustos 1951-Bakanlar Komitesi Taslağı, Kasım 1951-Bakanlar Komitesi Taslağı ve Aralık 1951-Danışma (Parlamenterler) Meclisi Taslağıdır. 2. maddenin dört farklı taslağında da devletin ebeveynlerin çocuklarını kendi dini ve felsefi inançları doğrultusunda eğitebilme haklarından söz edilmektedir. Hatta Kasım 1951-Bakanlar Komitesi taslağında, felsefi inanç sözcüğü kullanılmamış, yalnızca dini inanç ibaresi kullanılmıștır. Bununla birlikte ebeveynlerin çocuklarını kendi inançları doğrultusunda devlet okulları dışındaki okullara gönderebilme hakkından da söz edilmektedir. Ancak bu öneri kabul edilmemiştir. Aralık 1951-Danışma Meclisi taslağı nihai madde metni olarak kabul edilmiş ve Ek-1 No.lu Protokol'de yerini almıştır. ibid 201.

57 ibid 206-208. Her ne kadar kimi delegeler ebeveynlerin çocuklarını diledikleri biçimde eğitebilmeleri için devletin belli bir finansal destek sağlamasının gerekliliği yönünde görüş bildirmişlerse de, maddenin nihai metninde devletler açısından pozitif yükümlülük doğuracak bir dilden kaçınıldığı görülmektedir. Örneğin İngiliz delegesi, devletin ebeveynlerin çocuğun eğitimini sağlama hakkına sayg1 gösterme yükümlülüğünün, devlete makul olmayan düzeyde finansal yük oluşturmayacak biçimde kaleme alınması gerektiğini belirtirken, Hollanda delegesi devletin, ebeveynlere belli bir finansal destek sağlaması gerekliliği üzerinde durmuştur. ibid 206, 208. 
özgürlüğü) yönünden lex specialis olduğunu belirtmektedir ${ }^{58}$. AİHM bu davaya, ebeveynlerin çocuklarının kendi dini ve felsefi inançları doğrultusunda eğitim alması yönündeki talepleri ile devletin resmi eğitim müfredatının çatıştığı durumların konu olduğu daha sonraki davalarda da atıf yapmaktadır ${ }^{59}$. Bu tarz davalarda AïHM'nin, çoğulcu bir toplum yapısını muhafaza edecek nitelikte bir eğitimin sunulmasına ve öğrencilere belli bir ideolojinin aşılanmasının önüne geçilmesine önem verdiği görülmektedir. Mahkeme, hazırlık çalışmalarında üzerinde durulan, herkesin kendi tercihleri doğrultusunda eğitim alabilmesi için devletin etkili düzenlemeler yapma yükümlülüğünün olmadığını da çeşitli kararlarında vurgulamıştır ${ }^{60}$.

\footnotetext{
58 Folgerø and Others v. Norway, Başvuru No. 15472/02 (ECtHR, 29 June 2007) para 54.
}

AİHM, Norveç'te Hıristiyan olmayan ebeveynlerin çocuklarının, ilk ve orta öğretim düzeyinde zorunlu olarak okutulan "Hıristiyanlık, Din ve Felsefe" dersinden kendi talepleri doğrultusunda tamamen muaf tutulmaları yönündeki uygulamanın, AİHS'nin 9., 14. ve EP-1'in 2. maddesine aykırı olduğu gerekçesi ile yapılan başvuruda, eğitim hakkının, din ve vicdan özgürlüğü bakımından lex specialis olduğunu belirtmiş ve din ve vicdan hürriyeti bakımından ayrıca inceleme yapmamıştır. Bu uyuşmazlıkta AİHM, Norveç'in "Hıristiyanlık, Din ve Felsefe" dersinin müfredatını eleştirel ve çoğulcu bir içerikte düzenlememesi ve Hıristiyan olmayan ailelerin çocuklarına dersten ve dersin kimi ibadet uygulamalarından tamamen muaf tutulma dışında başka bir seçenek sunmaması nedeniyle, çocukların eğitim hakkının ihlal edildiği yönünde karar vermiștir. Bir başka ifade ile asıl tartışma devletin eğitim alanındaki pozitif yükümlülüklerinin derecesi ile ilgilidir. AİHM, hem devletin, devlet okullarında çoğulcu bir eğitim müfredatı uygulama yükümlülüğünden, özel okullarda alternatif bir eğitim müfredatının bulunmasını gerekçe göstererek kurtulamayacağını açıça belirtmekte ve eğitim hakkına belli açıdan pozitif bir anlam kazandırmış olmaktadır; hem de eğitim alanında uyguladığı takdir marjı doktrinine çoğulcu bir din ve ahlak eğitimi sunulması yönünden sınır getirmiș olmaktadır (para 101). AİHM, eğitim hakkını düzenleyen maddenin ikinci cümlesinin ratio legisinin çoğulcu bir din ve ahlak eğitimi sağlanması olduğunu belirtmektedir. Ancak AİHM'nin bu kararı oldukça tartışmalı ve 9 kabul oyuna karşılık, 8 ret oyuyla verilmiş "bıçak sırtı” bir karardır.

59 Dini inancı gereği çocuğunun okuldaki zorunlu yüzme dersine katılmasını istemeyen İsviçre vatandaşı ve Müslüman olan başvurucuya, İsviçre eğitim mevzuatına göre idari para cezası kesilmesinin konu edildiği uyușmazlık için bkz Osmanoğlı and Kocabaș v. Switzerland, Başvuru No. 29086/12 (ECtHR, 10 January 2017) paras 30, 90. Bu davada AİHM, 9. maddenin ihlal edilmediğine hükmetmiştir. İsviçre EP-1'e taraf olmadığı için AİHM eğitim hakkının AİHS'nin 9. maddesi açısından lex specialis olduğunu ve EP-1'in AİHS ile bir bütün olarak ele alınması gerekliliğini belirtmiștir. AİHM, bu kararda her ne kadar eğitim hakkı yönünden bir inceleme yapmadıysa da, kararda eğitim hakkına ilişkin ilkelere yer verilmiştir (paras 90, 91, 92). Diğer bir başvuru olan, İtalya'da eğitim yasası uyarınca okul sınıf duvarlarında haç bulunmasının eğitim hakkı ile din ve vicdan özgürlüğünü ihlal ettiği iddiası ile yapılan başvuru için bkz Lautsi and Others v. Italy, Başvuru No. $30814 / 06$ (ECtHR, 18 March 2011). Bu davada da eğitim hakkının, AİHS'nin 9. maddesi bakımından lex specialis olduğu belirtilmektedir (para 59). Başvurucu, okul duvarındaki haçın kaldırılması yönünde önce okul idaresine, oradan olumlu bir yanıt alamayınca idare mahkemesi, ardından da yüksek idare mahkemesine başvurmuştur. Yüksek idare mahkemesi haçın İtalyan medeniyetinde sahip olduğu hoşgörü, karșılıklı saygı, insanlar arasında ayrımçlık yapılmaması gibi anlamlara atıf yaparak, onun dini bir ifade olmadığını belirtmiş ve davacının talebini reddetmiştir. AİHM'de dava ilk olarak Dairede görülmüştür ve Daire sınıflarda haç bulunmasını hem din ve vicdan hürriyetinin hem de eğitim hakkının ihlali olarak değerlendirmiştir. Daireye göre haçın farklı anlamları olsa da dini anlamı ön plana çıkmaktadır (paras 30, 31, 32). Büyük Daire ise, sınıf duvarlarında haç bulunmasının - her ne kadar haç açıkça Hıristiyanlığın sembolü olsa da- öğrencilere endoktrinasyon uygulanması biçiminde anlașılarak, İtalya'nın eğitim hakkını ihlal ettiği sonucuna ulaşılamayacağına hükmetmiştir. Duvarda asılı duran haç, pasif bir semboldür ve aktif dini ritüellerin aksine öğrenciler üzerinde bir etkisi olmamaktadır (paras 71, 72). AİHM eğitim hakkının ihlal edilmediğine hükmederken, önemli bir gerekçe olarak İtalya'nın sınıf duvarlarında haç bulundurmasına rağmen, okul ortamını diğer dinlere de eşit biçimde açtığına ve bu sayede çoğulcu bir eğitim ortamı oluşturduğuna atıf yapmaktadır. Örneğin Müslüman öğrencilerin başörtüsü takması ve okullarda Ramazan ayının kutlanması gibi uygulamalar bulunmaktadır (para 74).

60 Osmanoğlu and Kocabaş v. Switzerland (n 59) başvurusunda ailenin, belli biçimdeki bir öğretimin sağlanması ya da derslerin belli biçimde organize edilmesi talepleri için AİHS'e dayanamayacağını belirtmiştir (para 95).

Lautsi and Others v. Italy (n 59) başvurusunda eğitim hakkını düzenleyen 2. maddede geçen devletin "sayg1 gösterme (respect)" yükümlülügünün yalnızca negatif yükümlülükleri kastetmediği, devletlerin eğitim hakkına yönelik pozitif yükümlülüklerinin de olduğu belirtilmektedir. Öte yandan devletler, bireylerin ve toplumun ihtiyaçları ve kaynaklar doğrultusunda gerekli tedbirleri alırken geniș bir takdir marjında da yararlanırlar. Eğitim hakkı özelinde ise ebeveynlerin, çocuklarının kendi tercihleri doğrultusunda eğitim alabilmesi için devletten belli bir tür öğretim sunulmasını talep etme hakkı bulunmamaktadır (para 61). Aynı açıklamalar Bulski-Polonya başvurusunda da yer almaktadır. Bulski v. Poland, Başvuru No. 46254/99 ve 31888/02 (ECtHR, 30 November 2004) paragraf numarası belirtilmemiştir.

Hatta AİHM, bir kararında kas distrofisi olan bir öğrencinin, kendi özel durumuna yönelik gereklilikleri (bir asansör) eğitim kurumlarından talep ettiği basvuruda dahi, söz konusu talebin devlet tarafından yerine getirilmemesini eğitim hakkının ihlali olarak değerlendirmemiştir. Burada Mahkeme, eğitim hakkının doğası gereği devlet tarafından düzenlenen bir hak olduğunu belirtmekte ve bireyler ile toplumun ihtiyaçlarına ve mevcut kaynaklara göre uyarlanabileceğinden söz etmektedir. Bkz. Mcintyre v. The United Kingdom, Başvuru no 29046/95(ECtHR, 21 October 1998) paragraf numaraları belirtilmemiştir. Benzer bir başka davada Komisyon (şimdi AİHM), devletin, mevcut kaynakların engelli öğrencilerin yararına kullanım biçimi konusunda geniş bir takdir yetkisi olduğunu belirtmiştir. AİHM'e göre EP-1'de düzenlenen eğitim hakkı, disleksik bir çocuğun, devlet okullarında özel sınıflar bulunmasına rağmen, tüm masrafları devlet tarafindan karşılanarak özel bir öğretim kurumunda okutulması yönünde bir talep yetkisi vermemektedir. Bkz. Simpson v. The United Kingdom, Başvuru No. 14688/89 (ECtHR, 4 December 1989) paragraf numaraları belirtilmemiştir. 
AİHM çeşitli kararlarında eğitimin mutlak bir hak olmadığını, doğası gereği devletlerin düzenlemesine ihtiyaç duyulan bir alan olduğunu ve Sözleşme'nin ilkelerine uygun olmak kaydıyla devletlerin bu hususta takdir marjından yararlandığını belirtmektedir ${ }^{61}$. Devletlerin takdir marji hususu elbette AİHS ile uyumlu olarak ele alınmaktadır. Bu açıdan, hakkın özüne dokunulmasına yol açmaması ve hakkın etkililiğini ortadan kaldırmaması için, eğitim hakkına yapılan müdahalelerin öngörülebilir olması ve meşru bir amaç gütmesi gerekmektedir. Bununla birlikte AİHM, eğitim hakkını sınırlandırma gerekçelerinin, Sözleşme'nin 8. (Özel ve Aile Hayatına Saygı Hakk1), 9. (Din ve Vicdan Özgürlüğü), 10. (İfade Özgürlüğü) ve 11. (Toplantı ve Dernek Kurma Özgürlüğü) maddelerinde yer alan ve tüketici bir biçimde yazılmış meşru sınırlama nedenleri ile sınırlı olmadı̆̆ııı da ifade etmektedir. O halde, ulaşılmak istenilen amaç ile, kullanılan araçların (tedbir/sınırlama/kısıtlama vb.) arasında makul bir ölçülülü̈k ilişkisi varsa, eğitim hakkına yapılan müdahaleler EP-1 ile uyumlu olacaktır ${ }^{62}$. Bununla birlikte hukuk devleti ilkesinin gerekleri ile demokratik toplumun gerekleri her daim göz önünde bulundurulan ölçütlerdir. Mahkeme'nin eğitim hakkı ile ilgili kararlarında yinelenen "çoğulcu toplum yapısı" vurgusu dikkat çekmektedir.

Eğitim hakkını daha çok negatif bir içerikte yorumlayan AİHM, bazı kararlarında eğitim hakkının diğer uluslararası sözleşmelerle uyumlu olarak yorumlanması gerektiğini de belirtmektedir. Örneğin AİHM, ileri derecede hipermetrop olan başvurucunun müzik akademisi yetenek sınavını kazanmasına rağmen görme duyusundaki aksaklık nedeniyle akademiye kaydının yapılmamasının eğitim hakkının ve ayrımcılık yasağının ihlali iddiası ile ilgili olan davada, uygun olan ve AİHS'nin de bir parçası olduğu her türlü uluslararası hukuk kuralının ve ilkesinin dikkate alınması gerektiğini belirtmiştir ${ }^{63}$. AİHM, eğitim kurumuna erişimde ayrımcılık ile ilgili olan bu davada, eğitim hakkının, Avrupa Sosyal Şartı'nda ve BM Engelli Kişilerin Hakları

61 Zorunlu yüzme dersinden muafiyet talebi reddedilen başvurucunun din ve vicdan hürriyetinin, eğitim hakkının devletlerin düzenlemesine ihtiyaç duyan bir hak olması gerekçesiyle ihlal edilmediği hakkında bkz (n 59) Osmanoğlu and Kocabaş v. Switzerland, Başvuru No. 29086/12 (ECtHR, 10 January 2017) para 92. Aynı kararda Mahkeme, özellikle eğitim ve öğretim alanına girdiği ölçüde devlet ve din ilişkisinin takdir marjı kapsamında değerlendirilmesi gerektiğini belirtmiştir (para 95). Burada Mahkeme ayrıca, yüzme dersinin tüm çocuklarla birlikte bir grup içinde yapılmasının, çocuğun yerel örf ve âdete uyum sağlaması açısından oldukça önemli olduğunu, çocuğun en yüksek yararı ilkesi gereği çocuğun yüzme dersine katılmasının, ailenin çocuğun yüzme dersinden muaf tutulması talebine üstün geldiğini ve İsviçre'nin hali hazırda öğrencinin istediği takdirde kapalı mayo giyebilmesine ve erkek öğrencilerin olmadığı soyunma odalarını ve duşları kullanabilmesine olanak tanıdığını belirtmiştir (paras 97, 98, 100, 101).

Benzer yönde ve aynı gerekçe ile zorunlu etik dersinden muafiyet talebi reddedilen başvurucunun eğitim hakkının ihlal edilmediği hakkında bkz Appel-Irrgang and Others v. Germany, Başvuru No. 45216/07 (ECtHR, 6 October 2009) paragraf numaraları belirtilmemiștir. Aynı kararda Mahkeme, devletin isteyen herkese farklı türde ahlak ve din dersi sunmasının da finansal bir mesele olduğunu ve bu nedenle Mahkeme'nin yetki alanına girmediğini belirtmiştir.

62 Özellikle Leyla Şahin-Türkiye Davası'nda bu ölçütü kabul ederek, ilgili açıklamaları yapmıştır. Leyla Şahin v. Turkey, Başvuru No. 44774/98 (ECtHR, 10 November 2005) para 154.

63 Çam v. Turkey, Başvuru No. 51500/08 (ECtHR, 23 February 2016), para 53. AİHM, adayın sınavı kazanmasına rağmen görme kusuru nedeniyle müzik akademisine kaydının yapılmamasını hem eğitim hakkının hem de ayrımcılık yasağının bir ihlali olarak değerlendirmiştir. Bununla birlikte Mahkeme hükmünü kurarken, AİHS'nin 14. maddesinin, BM Engelli Kişilerin Hakları Sözleşmesi'nin 2.maddesinde düzenlenen engelli kişilerin “bütün insan hakları ve özgürlüklerinden diğer bireylerle eşit biçimde yararlanma” hakkı ile birlikte ele alınması gerektiğini belirtmiştir (para 65). Böylelikle Mahkeme, AİHS'den başka bir uluslararası hukuk metnine doğrudan atıf yapmış olmaktadır. 
Sözleşmesi'nde öngörüldüğü biçimi ile dikkate alınması gerektiğini belirtmektedir. Birey olarak insanların korumanın bir aracı olan AİHS'nin amacı, bireylere sağladığı garantilerin etkili bir koruma sağlayacak biçimde yorumlanıp uygulanmasını gerektirmektedir ${ }^{64}$. AİHM, eğitim kurumuna kayıt başvurusunun reddedildiği bir başka davada, demokratik bir toplumda eğitim hakkının insan haklarının geliştirilmesi için vazgeçilmez bir hak olduğunu ve EP-1'in 2. maddesinin ilk cümlesinin ("Hiç kimse eğitim hakkından yoksun birakilamaz.") dar yorumlanmasının, maddenin hedef ve amacı ile bağdaşmayacağını belirtmektedir ${ }^{65}$. Mahkeme bununla birlikte bu yöndeki yaklaşımın aynı zamanda BMIHEB (m. 26), BMESKHS (m. 13), BMÇHS' $\mathrm{de}^{66} \mathrm{de}$ (m. 28) yer aldığını ifade etmiş ve ilgili hükümlere karar metni içinde yer vermiştir ${ }^{67}$. AİHM'nin eğitim hakkı özelinde diğer BM insan hakları belgelerine atıf yapması ve bu sayede eğitim hakkının kapsamını genişletmesi eğilimi oldukça önemlidir ${ }^{68}$.

Mahkeme eğitim hakkını, eğitime erişim kısıtlamaları ve eğitime erişimde ayrımcılık (özellikle AİHS'nin 14. maddesine de atıf yaparak) çerçevesinde ele almaktadir ${ }^{69}$.

\section{A. Hastalık Nedeniyle Eğitime Erișim Engeli}

Konumuz açısından AİHM kararları çerçevesinde önem arz edecek hususlar să̆glk nedeniyle ĕgitime erişimin kisıtlanması ve özellikle engellilik nedeniyle ĕgitime erişimde ayrımcılık olabilir. İlerleyen zamanlarda eğitim-öğretim kurumları tekrar yüz yüze eğitme geçtiğinde, hastalık belirtisi göstermeyen ve tamamen "sağlıklı"

64 ibid para 53.

65 Timishev v. Russia, Başvuru No. 55762/00 ve 55974/00, (ECtHR, 13 December 2005) para 64.

66 AİHM, bir davada da doğrudan BM Çocuk Hakları Sözleşmesi’ne atıf yapmıştır. Bkz. Ponomaryovi v. Bulgaria, Başvuru No. 5335/05, (ECtHR, 21 June 2011) para 57.

67 Ponomaryovi v. Bulgaria, para 64.

682016 senesinde Macaristan'da yaşayan bir grup Roman çocuğun, daha önce okudukları ve kendilerine okula ulaşım imkânı sağlayan bir okuldan, Yunan Katolik Kilisesi'nin kurmuş olduğu ve okula ulaşım imkânı sağlamayan bir okula nakledilmesi nedeniyle, Roman yerleşim yerlerinden yeni okula ulaşım sağlayamamaları ve bu nedenle derslere katılamamaları, eğitim hakkının ihlali iddiası ile AİHM'nin önüne gelmiştir. Söz konusu dava AİHM'nin eğitim hakkını BM Ekonomik, Sosyal, Kültürel Haklar Komitesinin 13 No.lu Genel Yorumunda belirtilen kapsamıyla ele alması için bir firsat olarak değerlendirilmiştir. James Rooney, 'European Court of Human Rights to Consider Right to Education' (Oxford Human Rights Hub, 21 Ekim 2016) < http://ohrh.law.ox.ac.uk/european-court-of-human-rights-to-consider-right-to-education/> erişim tarihi: 14 Ağustos 2020 .

Hatırlanacak olursa 13 No.lu Genel Yorumda eğitim hakkının okula fiziki erişim de kapsadığı belirtilmekteydi. Ancak AİHM, davayı iç hukuk yollarının tüketilmemiş olması gerekçesi ile reddetmiştir. Bkz. Amanda Kosa v. Hungary, Başvuru No. 53461/15 (ECtHR, 21 November 2017).

69 Çalışmanın kapsamını aşacağından eğitim hakkına yönelik tartışmaların tümüne yer verilmesi mümkün olmamıştır. Eğitime erişim kısıtlamaları eğitim hakkını düzenleyen 2.maddenin 1. cümlesi kapsamında ele alınmaktadır. Buna göre, dil, okullara kabul ölçütleri ve çeşitli kısıtlamalar öngören giriş sınavları, okul ücretleri, uyruk, belli eğitim yeterlilik belgeleri alınabilmesi için asgari yaş sınırları öngörülmesi, hapishanedekilerin eğitime erişimi konusu, ceza soruşturması nedeniyle eğitime erişememe, sınır dışı edilme nedeniyle eğitime erişememe, eğitimde çeşitli disiplin cezalarının uygulanmasının eğitime erişim engeli oluşturup oluşturmadığı, hastalık sebebiyle diğerlerini korumak için hasta kişinin eğitime erişiminin engellenmesi gibi çok sayıda olabilmektedir. Eğitime erişimde ayrımcılık ise, engelli kişilerin eğitime erişimine yönelik kısıtlamalar, örneğin görme engeli olan kişinin sınavı kazanmasına rağmen kaydını yapmayan müzik akademisi, uyruk ve ülkede bulunma statüsü nedeniyle eğitime erişimde ayrımcılık, etnik köken nedeniyle erişimde ayrımcılık konularında da birçok kararı bulunmaktadır. 2. maddenin 2. cümlesi de ebeveynlerin çocuğu eğitme hakkına saygıyı düzenlemektedir. Tüm bu konular hakkındaki çok sayıda karar özeti için bkz Council of Europe/European Court of Human Rights, 'Guide on Article 2 of Protocol No. 1 to the European Convention on Human Rights, Right to Education' (2019). 
olarak görülen, ancak genel bir tarama yapılması halinde COVID-19 pozitif çıkan öğrencilerin, yüksek bulaşıcılık riski taşıması nedeniyle eğitim kurumuna alınmamaları ile ilgili uyuşmazlıkların ortaya çıkması muhtemeldir. AİHM Yunanistan'a ilişkin 2016 tarihli güncel bir kararında ${ }^{70}$, bulaşıc1 olan cüzzam hastalığ 1 teşhisi konulan ve daha sonradan ikinci bir hastane nezdinde bunun yanlış olduğu anlaşılan, 7 ve 11 yaşlarındaki Arnavutluk vatandaşı iki çocuğun, 4 aylık bir süre ile okula gidememelerini eğitim hakkının ihlali olarak değerlendirmiştir. Mahkeme burada, idarenin, hastalı̆̆ı yayllma riskini önlemek için uygun bütün tedbirleri alabileceğinde hemfikirdir. Bu açıdan öğrencilerin bulaşıcı olan cüzzam hastalığını taşıdıkları yönündeki ilk hekim raporuna dayanan okul idaresinin kararı, eğitim hakkına bir müdahale teşkil etmekle birlikte, bu müdahale meşru bir amaca-okuldaki diğer öğrencilerin ve öğretmenlerin sağllğını korumak- hizmet etmektedir. Ancak, bir topluluğun sağlık hakkı ile bireyin eğitim hakkının yarıştığı böylesine bir durumda, idare ölçülülük ilkesini gözeterek, özenli ve hızlı davranma yükümlülüğü altındadır. Kısıtlayıcı ve külfetli önlemler, ancak arzulanan amaca ulaşabilmek için gerekli olduğu ölçüde uygulanmalıdır ve uygulanmalarını gerektirecek nedenler ortadan kalktığı anda sonlandırılmalıdır. Somut olayda, cüzzam teşhisi konan çocukların sonradan hastalığı yayma riski taşımadığı anlaşılmasına rağmen, çocukların cüzzam olmadığını söyleyen ikinci hastanenin çocukların okula dönebilmeleri kararını ilgili kurula bırakması ve idarenin okuldan uzaklaştırma tedbirini kurul kararı gelene kadar uygulamaya devam etmesi durumu söz konusudur. İlgili kurul ise Eylül ayında okullar açılmasına rağmen ancak Aralık ayında toplanarak çocukların okula dönebilmelerini onaylamıştır. AİHM'ye göre, bu türden bir gecikme, ulaşılmak istenen meşru amaç doğrultusunda ölçülü olmamıştır. Bu gerekçeyle çocukların okula erişimlerinin engellenmesi eğitim hakkının ihlalidir. Yargılama sonunda Yunanistan, her iki çocuğa da 5000'er Avro tazminat ve ayrıca 2000 Avro tutarında yargılama masraflarını ödemekle yükümlü kılınmıştır ${ }^{71}$.

Neler Yapılabilir? Bu somut olaydan çıkartılabilecek temel ilke kanımızca eğitimöğretime ilişkin talepler ve uyuşmazlıklar söz konusu olduğunda süre unsurunun oldukça önemli olduğudur ${ }^{72}$. Bu nedenle gerek idari yargılama hukukunda, gerekse okul ve yükseköğretim kurumlarının idarelerinin yapacakları işlem ve eylemlerde sürelerin hak kayıplarına yol açmayacak biçimde düzenlenmesi ya da uygulanması söz konusu olacaktır. Örneğin çok kısa süreler nedeniyle COVID-19 salgını süresince belli başvuruları kaçıran öğrenciler açısından ek süreler tanınmalıdır. Yine öğrencileri ilgilendiren konularda belli kararlar alınacağı zaman -hem idari süreçte hem de yargı sürecinde- meselenin ivedilikle çözülmesi gerekecektir. Bu hususlara

\footnotetext{
Memlika v. Greece, Başvuru No. 37991/12 (ECtHR, 6 October 2015).

71 Memlika v. Greece, Başvuru No. 37991/12 (ECtHR, 6 October 2015) para 55.

72 Millî Eğitim Bakanlığı Okul Öncesi Eğitim ve İlköğretim Kurumları Yönetmeliği, madde 18/(4): "Bulaşıcı bir hastalık nedeniyle okula devam edemeyen çocuklar, sakınca olmadığına ilişkin sağlık kuruluşlarından alınacak rapor ile kuruma devam edebilirler." RG 26.07.2014-29072.
} 
dikkat edilmediği takdirde Türkiye'de de eğitimde süreler nedeniyle yaşanan hak kayıpları ve dolayısıyla eğitim hakkı ihlal iddiaları yargının önüne gelebilir. Öte yandan tehlikeli salgın hastalık (pandemi) olan COVID-19 taşıyan ancak hiçbir belirti göstermeyen bir öğrencinin, bunu okuldaki diğer kişilere de bulaştırması tıbbi açıklamalar doğrultusunda söz konusu olduğu için, okula alınmaması, eğitim hakkına meşru bir müdahale teşkil edecektir. Elbette idarelerin çocuğun sinavlara girebilmesi ya da süreç içinde uzaktan eğitime devam edebilmesi ile ilgili asgari önlemleri alması gerekecektir. Özellikle COVID-19 nedeniyle kronik rahatsızlığı olan ve diğer çocuklar ile aynı anda okula başlayamayan çocuklarla ilgili önlemler mutlaka alınmalıdır ${ }^{73}$. Okulların müfredatı eğitim-öğretim dönemi başında belirlenmiş olduğu için, COVID-19 pozitif olan ancak herhangi bir hastalık belirtisi göstermeyen ve okula gidemeyen öğrencilere, kronik rahatsızlığı olan öğrencilere ve evde kronik rahatsızlığı olan ebeveynlerle yaşayan öğrencilere, ilgili sağlık uzmanlarının raporu doğrultusunda, evde bulundukları süre boyunca uzaktan eğitim olanağı sağlanabilir. $\mathrm{Bu}$ gibi öğrencilerin sınavları, okulda onlara özel olarak ayrılmış bir odada ya da okulun boş olduğu bir günde / saatte yapılabilir ${ }^{74}$.

\section{B. Eğitime Erişimde Ayrımcılık}

Yukarıda BM'nin ilgili komite raporlarında da belirtildiği gibi eğitime erişimde elverişsiz konumda bulunan öğrenciler olabilir. Özellikle uzaktan eğitim, önceden var olan sosyal eşitsizlikleri pekiştirme potansiyeli taşımaktadır. Bu konu ayrımcılık yasağı kapsamında ele alınmaktadır. Ayrımcılık çok çeşitli biçimlerde ortaya çıkabileceği için, AİHM ayrımcılığın ortaya çıkıp çıkmadığını somut olaya göre değerlendirmekte ve ayrımcılıkla ilgili kesin bir ölçüt uygulamamaktadır. AİHM,

\footnotetext{
Millı̂ Eğitim Bakanlığı Okul Öncesi Eğitim ve İlköğretim Kurumları Yönetmeliği, madde 32/3: "Sağllk durumu nedeniyle okula devam etmesinin uygun olmadı̆̆ına ilişkin sağlık kurulu raporu alanlar, raporları süresince izinli sayılırlar. Bu sürenin bitiminde ögrencilerin okula devamlart sağlanır. Bu öğrenciler okula döndüklerinde, devam edemedikleri eğitim ve ögretim yllına ait derslerden okul müdürünün sorumluluğu ve koordinesinde, alan öğretmenlerinden oluşturulacak komisyonca sınava alınır. Başarılı olanlar bir üst sınıfa devam ettirilir." Kanımızca okul öncesi, ilköğretim kurumları ve orta öğretim kurumları yönetmeliklerine sınav hakkının yanında, okula gelemedikleri zaman boyunca uzaktan eğitim olanağının da sağlanması düşünülebilir. İlgili maddeye bu hususta bir hüküm eklenmelidir.

Benzer önlemler Almanya'nın kimi eyaletlerinde de alınmaktadır. Örneğin Nordrhein-Westfalen Eyaleti'nde okulların kademeli olarak 7 Mayıs 2020'den itibaren açılması öngörülmüştür. Burada, kronik rahatsızlığı olan çocuklar ile, kronik rahatsızlığı olan ebeveynlerle aynı evde yaşayan çocukların, ilgili doktor raporu ile okula gelmemesi söz konusu olabilir. Bu durumda da okul, çocuğa uzaktan eğitim sunmalı ve çocuğun sınavlara ayrı bir gün ve odada girmesini sağlamalıdır. Bkz. Ministerium für Schule und Bildung des Landes Nordrhein-Westfalen [NRW Eyaleti Eğitim Bakanlığl] <https://www.schulministerium.nrw.de/docs/ Recht/Schulgesundheitsrecht/Infektionsschutz/300-Coronavirus/index.html> erişim tarihi 15 Mayıs 2020.

Benzer bir önlem ABD Hükümeti Eğitim Departmanı'nın okullarda ayrımcılığın önlenmesine yönelik yayımladığı bilgilendirme notunda da yer almaktadır. Bir sağlık uzmanı tarafından COVID-19 nedeniyle, herhangi bir engeli veya kronik rahatsızlık gibi özel durumları olan çocukların, okula diğer çocuklardan daha geç başlamasının öngörülmesi halinde, okullar bu çocukların eğitim-öğretimi kaçırmaması için gerekli tedbiri alacalardır. Bkz. 'Fact Sheet: Addressing the Risk of COVID-19 in Schools While Protecting the Civil Rights of Students' (United States Department of Education Office for Civil Rights, 16 March 2020) 2.

7412 Ağustos 2020 tarihinde Milli Eğitim Bakanlığı 2020-2021 eğitim-öğretim yılının Bilim Kurulu tavsiyeleri doğrultusunda "aşamalı ve seyreltilmiş" olarak yapılacağını açıklamıştır. Eğitim hem interaktif ve teknoloji destekli, hem de seyreltilmiş biçimde yüz yüze yapılacaktır. Okullarda bulunan tüm personelin ve öğrencilerin sağlık durumları HES kodları ile takip edilecektir. Okullarda teneffüslere ilişkin standartlar yayınlanacak rehberde yer alacaktır. Basın açıklaması için bkz 'Okulları Birlikte AçacağıZ' (Milli Eğitim Bakanlığı, 12 Ağustos 2020) <http://www.meb.gov.tr/okullari-birlikte-acacagiz/ haber/21424/tr> erişim tarihi 15 Ağustos 2020.
} 
önüne gelen olayda kamu otoritelerinin eşit davranmama gerekçesinin makul ve objektif olmadığına kanaat getirirse, ya da farklı davranma ölçülü değilse, ya da farklı muamele ile ulaşılmak istenen hedef meşru bir sonuç olarak nitelendirilemiyorsa, söz konusu olayda ayrımcılık olduğuna hükmedebilir ${ }^{75}$.

Uzaktan ya da açık eğitim-öğretim aslında tam da eğitime erişimi olmayan elverişsiz sosyal gruplardan gelen, savaş ve çatışma bölgelerinde bulunan, elverişsiz kırsal bölgelerde yaşayan ya da salgın hastalıklar söz konusu olup okullar kapandığında ${ }^{76}$, öğrencilerin eğitim hakkını kullanabilmeleri için düşünülmüş bir eğitim metodudur. Yani aslında ilk olarak eğitime erişimi olmayanların eğitimden dışlanmaması için düşünülmüştür ${ }^{77}$. Ancak uzaktan eğitime ilişkin eleştirel yaklaşımlar, bu türden eğitimin zaten toplumdan dışlanan insanların, bu şekilde daha da dışlandığın $1^{78}$ ya da teknik olanaklar açısından eşit olmayan öğrenciler açısından da firsat eşitsizliği ortaya çıkartma tehlikesi barındırdığını belirtmektedir ${ }^{79}$.

Salgın hastalık süresince eğitime erişimde ayrımcılık iki biçimde ortaya çıkabilir. İlki uzaktan eğitim materyalinin, eğitim biçiminin ve sınavların engelli kişilere uygun hazırlanamaması; ikincisi de yoksulluk veya teknik imkânsızlı nedeniyle zorunlu olarak geçilen uzaktan eğitime hiç veya gereği gibi erişememedir. Okullar ve üniversiteler zorunlu uzaktan eğitim süresince hak ihlal iddiaları ile karşılaşmamak için eğitim müfredatını alternatifli hazırlamalıdır. Örneğin yazılı bir metnin, görme engeli olanlar için sesli okuma yapan programlara uygun formatta da hazırlanması gibi ${ }^{80}$.

AİHM'nin engellilik nedeniyle eğitime erişimin engellendiği uyuşmazlıklara ilişkin farklı kararları bulunmaktadır. AİHM'nin genel yaklaşımı, devletlerin bu konuda takdir yetkilerinin oldukça geniş olduğu ve eğitime ilişkin pozitif edimlerin devletlerin

75 İlyas Doğan, İnsan Hakları Hukuku (3. Bası Astana Yayınları, 2019) 837.

76 Örneğin 1922 tarihinde Yeni Zelanda' daki influenza salgını nedeniyle okullara erişim bir süre söz konusu olmamıştır. 1939 yılında Kanada'nın New Brunswick bölgesinde çocuk felci (polio) salgını zamanında okullara erişim mümkün olmamıştır. $\mathrm{Bu}$ yıllarda ülkelerin çeşitli bölgelerinde o tarihte "yazışma eğitimi (correspondance education)" olarak adlandırılan uzaktan eğitim metodu uygulanmaya başlanmıştır. Yine benzer şekilde II. Dünya Savaşı sırasında da bölgelerinden uzaklaşmak zorunda kalan Kanadalı askerler ve Fransa'da Fransız çocuklar için uzaktan eğitim uygulaması yapılmıştır. Bu uygulamalar daha sonra Avrupa ülkelerinde de yaygınlaşarak tele-eğitim gibi biçimlerde devam etmiştir. Bkz. Margaret Haughey/Elizabeth Murphy/Bill Muirhead, 'Open Schooling' içinde Terry Evans and others (eds), International Handbook of Distance Education (Emerald 2008) 148.

77 ibid 148,149

78 Anthony Smith/Frank Webster, 'Changing Ideas of the Universty' içinde Anthony Smith ve Frank Webster (eds), The Postmodern Univeristy? Contested Visions of Higher Education in Society (Open University Press 1997) 12.

79 Christopher Newell, 'Distance Education: Enabling and Disabling?' içinde Terry Evans and others (eds), International Handbook of Distance Education (Emerald 2008) 87.

80 Dijital ortamda gerçekleştirilecek sınavlara ilişkin esaslar duyurulmuştur. Bkz. <https://www.yok.gov.tr/Sayfalar/ Haberler/2020/universitelerde-dijital-sinavlarin-temel-ilkeleri.aspx> erişim tarihi 15 Ağustos 2020. Tez aşamasında olan lisansüstü öğrencilere ek süre tanınmıştır. Bkz. Lisansüstü Eğitim ve Öğretim Yönetmeliğinde Değişiklik Yapılmasına Dair Yönetmelik, RG 10.06.2020-31151. 
kaynakları ile yakından ilgili olduğu yönündedir ${ }^{81}$. Mahkeme önceleri daha çok ĕgitimde sistematik ayrımcılık konuları ile ilgili ihlal kararı vermekte ${ }^{82}$ ve engellilere yönelik tekil durumları eğitim hakkının ihlali olarak değerlendirmemekteydi ${ }^{83}$. Ancak sonradan, eğitim hakkına ilişkin uluslararası gelişmeler doğrultusunda, engelli kişilerin herkes gibi bütün insan hak ve özgürlüklerinden eşit olarak yararlanabilmeleri için, devlet tarafından "somut olaya özgü ve ilgili kişiye orantısız ya da aşırı külfet yüklemeyen düzenlemeler ve tedbirler alınması" gerekliliğine dikkat çekmiştir. Alınacak önlemleri, ulusal otoriteler somut olaya özgü koşullar temelinde değerlendirecektir; bu önlemler fiili eşitsizlikleri ortadan kaldıracak her biçimde olabilir ${ }^{84}$.

81 AïHM, Martin Klerks-Hollanda başvurusunda, işitme kaybı olan bir çocuğun normal okula devam etmesini ve çocuk için fazladan bir öğretmen bulundurulmasını talep eden ailenin bu yöndeki talebinin okul tarafindan reddedilmesini eğitim hakkının ihlali olarak değerlendirmemiștir. Martin Klerks v.Netherlands, Başvuru No. 25212/94 (ECtHR, 4 July 1995) paragraf numaraları belirtilmemiştir. Bu davada 2. maddenin 2. cümlesine (ebeveynlerin çocuklarını kendi dini ve felsefi görüşleri doğrultusunda eğitme hakkına) dayanılmasının nedeni, ailenin işitme kaybı olan çocuğun normal okulda eğitim görmesini istemelerinin kendi felsefi inanışları olduğunu savunmalarıdır. Komisyon (AİHM), engelli çocukların kendilerine özgü okullarda değil de kendi yaşıtları olan diğer çocuklarla aynı okulda okumalarının onların yararına olduğu yönündeki pedagojik görüşleri kabul ettiğini belirtmiştir. Ancak bunun yanında böylesine bir politikanın bütün engelli çocuklara uygulanması mümkün olmadığı gibi, ilgili kamu otoriteleri mevcut kaynaklar doğrultusunda bütün engelli çocukların yararına politikalar belirleme konusunda geniş takdir yetkisine sahiptir. ibid (paragraf numaraları belirtilmemiştir).

AİHM aynı görüşünü kas distrofisi olan öğrenci için okulun asansör yaptırmamasının eğitim hakkının ihlali olmadığı hakkındaki Mcintyre-Birleşik Krallık davasında da tekrarlamıştır. Mcintyre v. United Kingdom (n 60).

82 Özellikle Hırvatistan, Yunanistan, Macaristan ve Çek Cumhuriyeti’nde yaşayan Roman çocukların eğitim alanında sistematik olarak ayrımcı muamelelere maruz kaldıkları çeşitli olaylar AİHM tarafından değerlendirilmiş ve eğitim hakkının ihlaline hükmedilmiştir. Roman çocukların Çek Cumhuriyeti'nde sistematik olarak ayrı ve özel eğitim ihtiyacı olan öğrencilerin gittiği okullara devam etmesinin eğitim hakkı ve ayrımcılık yasağının ihlali olduğu hakkındaki dava için bkz D.H. and Others v. The Czech Republic, Başvuru No. 57325/00 (ECtHR, 13 November 2007). Macaristan'da1970'li yıllardan bu yana Roman çocukların zekâ testine tabi tutularak hatalı olarak zihinsel engelli olarak değerlendirilmesi ve ayrı okullarda okutulmasının sistematik bir ayrımcılık teșkil ettiği ve eğitim hakkının ihlali olduğu hakkındaki dava için bkz Horváth And Kiss v. Hungary, Başvuru No. 11146/11 (ECtHR, 29 January 2013). Hırvatistan'a ilişsin bir davada Mahkeme Çek Cumhuriyeti, Yunanistan ve Macaristan'daki gibi sistematik bir ayrımcılık söz konusu olmadığını belirtmiştir. Ancak Roman çocukların okullarda okuma güçlügüü çektikleri gerekçesiyle devamlı olarak ayrı sınıflara alınması uygulamasını ve yalnızca Roman çocukların bu şekilde bir muameleye maruz kalmasını "dolaylı bir ayrımcılık" olarak değerlendirmiştir. Bu davada da eğitim hakkı ile birlikte ayrımcılık yasağının ihlaline hükmetmiştir. Oršuš and Others v. Croatia, Başvuru No. 15766/03 (ECtHR, 16 March 2020) paras 152, 153.

83 Kalkanlı-Türkiye kararında AİHM, görme engeli olan bir öğrencinin normal bir vakıf okuluna devam etmek istemesine rağmen, okulun öğrencinin kaydını yapmamasını eğitim hakkının ihlali olarak değerlendirmemiştir. Burada AİHM özellikle yalnızca bir okulun bu şekilde bir kayıt yapmamasının kendi içinde devlet otoriteleri tarafından öğrencinin eğitim hakkını ihlal ettiği anlamının çıkartılmayacağını vurgulamıştır. Bu kararında AİHM Türk hukukunda eğitim hakkının AİHS ile uyumlu olarak düzenlenip düzenlenmediğini tartışmıș ve Türkiye'nin özel gereksinimi olan öğrencilerin eğitim hakkını etkin bir şekilde sağladığı sonucuna varmıştır. Mahkeme Türkiye'de engelli öğrencilere yönelik sistematik bir ayrımcılık ya da eğitime erişim engeli olmadığı sonucuna vararak, tek bir okulun bir engelli öğrencinin kaydını imkân yetersizliği nedeniyle yapmamasını, devletin eğitim hakkına ilişkin yükümlülüklerinin ihlali olarak değerlendirmemiştir. Kalkanlı v. Turkey, Başvuru No. 2600/04 (ECtHR, 13 January 2009) paragraf numaraları belirtilmemiştir.

${ }^{84} \mathrm{Bu}$ yorum, AİHM'nin, Enver Şahin-Türkiye ve Çam-Türkiye (n 63) davalarında kullandığı yorumdur. Enver Şahin başvurusunda, sonradan belden aşağısı felçli olan bir öğrenci üniversite yönetiminden, eğitim-öğretime devam edebilmek için gerekli düzenlemelerin yapılmasını istemiştir. Üniversite, talebi açıkça reddetmemiş ancak, kaynak yetersizliğini gerekçe göstererek, öğrencinin talebinin kısa sürede yerine getirilemeyeceğini söylemiş ve öğrenciye kampüs içinde sürekli yardımcı olacak birisini görevlendirmeyi önermiştir. AİHM, üniversitenin bir kişi görevlendirmesi önerisinin, Sözleşme'nin 8. maddesinde garanti altına alınan özel hayata saygı hakkı çerçevesinde makul bir tedbir olmadığını, üniversite yönetiminin öğrencinin mümkün olduğu ölçüde bağımsız ve özerk bir biçimde hayatını devam ettirebilmesi gerekliliğini dikkate almadığını belirterek, hem 14. maddenin hem de 14. madde ile bağlantılı olarak eğitim hakkının ihlaline hükmetmiştir. Enver Şahin v. Turkey, Başvuru No. 23065/12 (ECtHR, 30 January 2018) paras 67, 68.

Çam v. Turkey,(n 63) para 65. AİHM, Çam-Türkiye davasında kamu otoritesinin, görme engeli olan öğrencinin kazandığı müzik akademisinde neden müzik eğitimi alamayacağını açıklayamadığını, öğrencinin görme engeline yönelik ders materyali, ders ortamı vb. koşullarda bazı fiziksel uyarlamalar yapılmasının mümkün olup olmadığını hiç değerlendirmediğini belirtmiştir. Mahkeme, öğrencinin müzik akademisine kaydının yapılmamasının yalnızca görme engeline dayandığını vurgulamış ve eğitim hakkı ile bağlantılı olarak ayrımcılık yasağının ihlaline hükmetmiştir (paras 68, 69). 
Zorunlu uzaktan eğitime erişim için yeterli alt yapısı veya kaynağı olmayanlar açısından ayrımcılık yasağının ve eğitim hakkının ihlalinin gündeme gelip gelmeyeceği tartışmaları da önemlidir. AİHM'nin yukarıda atıf yapılan içtihadı doğrultusunda devletlerin, kişilere orantısız ya da aşırı külfetler yüklemeyen tedbirler alması gerekecektir. Bu açıdan eğitimin devam edebilmesi için alınan tedbirler nedeniyle bazı öğrenciler açısından orantısız ya da aşırı külfetler ortaya çıkıyorsa eğitim hakkının ihlali ile birlikte ayrımcılık yasağının ihlali de gündeme gelebilir.

COVID-19 salgını nedeniyle farklı bir ülkeden gelen (özellikle Çin, Uzak Doğu gibi) ya da farklı bir etnik gruba ait olan öğrenci veya kişiler de eğitim alanında ayrımcı muameleye maruz kalabilir. Burada ayrımcılık bir kamu otoritesinin doğrudan ayrımcı bir uygulama yapması biçiminde değil de, okul ortamında diğer öğrenciler, öğrenci velileri ya da eğitim personeli tarafından dışlanma / aşağılanma biçiminde ortaya çıkabilir. AİHM, Yunanistan'ın Sofades bölgesinde yaşayan Roman ailelerin çocuklarının fiili bir uygulama olarak bölgede yer alan dört okuldan yalnızca birine kayıtlarının kabul edilmesini, hem eğitim hakkının hem de ayrımcılık yasağının ihlali olarak değerlendirmiş̧ir. Bu davada Yunanistan Eğitim Bakanlığı bölgedeki Roman çocukların ayrımcı muameleye maruz kaldığını kabul edip bir dizi önlem alacağını belirtmekle beraber, bölgedeki Roman olmayan velilerin yoğun tepkisi ve baskısı nedeniyle Roman çocukları diğer Yunan okullarına yerleştirememiştir. AİHM, olayda devletin ayrımcılık yapma kastının bulunmamasını yeterli görmemiş; Roman olmayan velilerin yoğun muhalefeti gerekçesini de ayrımcı muamele açısından meşru bir amaç olarak değerlendirmemiştir ${ }^{85}$. Benzer endişelerle ABD Hükümeti Eğitim Departmanı, COVID-19 süresince öğrencilerin medeni haklarının korunması için tüm eğitim kurumu idarecilerine yönelik bir bilgilendirme yayımlamıştır ${ }^{86}$. Burada hem okullar açıldığına belli irk, ülke, köken vb. temelli ayrımcılığın ve akran zorbalı̆ı̆ının önlenmesi (özellikle Çin ve Uzak Doğu kökenlilere) hem de öğrencilerin hiçbir şekilde eğitime erişimde ayrımcı muameleye maruz kalmaması gerektiği belirtilmektedir. Ülkemizde de YÖK, üniversitelerde benzer tedbirler alınmasi gerektiğini belirtmektedir ${ }^{87}$.

Neler Yapılabilir? Kanımızca Türkiye'deki kayıt dondurma uygulaması, eğitime erişimde ayrımcılığın önlenmesi ve firsat eşitliğinin sağlanması bakımından mevcut yasal olanaklar çerçevesinde makul bir tedbir olarak değerlendirilebilir. Uluslararası

\footnotetext{
Lavida And Others v. Greece, Başvuru No. 7973/10 (ECtHR, 30 May 2013) paras 72, 73.

86 'Fact Sheet: Addressing the Risk of COVID-19 in Schools While Protecting the Civil Rights of Students' (United States Department of Education Office for Civil Rights, 16 March 2020) 2.

87 Nitekim Türkiye'de YÖK bu konu hakkında bir dizi önlem alınması hakkında üniversitelere çağrı yapmıştır. YÖK 20 Nisan 2020 tarihli açıklama: "6 Mart’ta, yani ülkemizde henüz herhangi bir vaka tespit edilmeden önce, yüksekögretim kurumlarında COVID-19 hastalığına ilişkin alınması gereken tedbirler, "Seyahat ve Yurtdıșı Toplantılar", "Uluslararası Katılımlı Toplantılar", ve "Ayrımcılığa Karşı Alınacak Tedbirler" halinde ü̧̧ başlıkta toplanmış ve ülkemizdeki yabancı uyruklu ögrenciler de dikkate alınarak üç dilde yükseköğretim kurumlarımıza gönderilmiştir." 'Pandemi Günlerinde Türk Yükseköğretimi' (YÖK, 20 Nisan 2020) <https://covid19.yok.gov.tr/Sayfalar/HaberDuyuru/pandemi-gunlerinde-turkyuksekogretimi.aspx> erişim tarihi 15 Ağustos 2020.
} 
çeşitli örnekler incelendiğinde COVID-19 döneminin, üniversitelerde nötr-dönem ${ }^{88}$ olarak adlandırıldığı görülmektedir. Bunun anlamı, kayıt dondurma uygulamasından biraz daha farklıdır. Öğrenciler istedikleri takdirde üniversitelerinin aldığı önlemlere göre döneme devam edebilmekte, ancak dönem sonunda sinavlara girmiş olsun ya da olmasın, istedikleri dersleri ya da tüm dönemi transkriptlerine yazdırmama hakkına ve okul açıldığında ilgili dersleri yeniden alma hakkına sahiptir ${ }^{89}$. Bu da elbette öğrencilerin uzaktan eğitim süresince başarısız oldukları ya da düşük not aldıkları derslerin dönem ortalamalarına (GANO) etki etmemesini sağlayacaktır. Öğrenci ilgili dersi yüz yüze eğitim başladığında ilk defa alıyormuş gibi alabilecektir. Bu yöntem Türkiye'de öğretim programları daha katı düzenlenmiş olduğu için bir sonraki yıl ve dönemde çok sayıda dersin çakışmasına yol açabilir; bu açıdan ülkemizde uygulanmaya pek uygun değildir. Ancak yine de, COVID-19 süresince yapılan ve teknik donanım yetersizliği nedeniyle sınavına girilemeyen derslerin, yüz yüze sınav yapma imkânı doğana ve öğrenciye sınavı yapılana kadar, ANO ve GANO hesaplamalarına katılmaması veya üniversite yönetmeliklerindeki mazeret sınavı hakkının esnekleştirilmesi hususları düşünülebilir. Türkiye'de GANO -burs, yurtlardan faydalanma, üstten ders alabilme, belirli dersleri seçebilme, yan dal yapabilme gibi- birçok husus için belirleyicidir. Kanımızca gelecek dönemlerde bu hususlarda uyuşmazlıklar ortaya çıkabilir. Bunun önüne geçmek için, COVID-19 süresince yalnızca teknik imkânları olmadığından ötürü sınavına girilemeyen derslerin değil; sınavına girilen ve (koşullu başarılı olan DC, DD ve başarısız olan FD ve FF) başarısız olunan derslerin de öğrencinin talebi doğrultusunda GANO hesaplamasında bir defaya mahsus dikkate alınmaması sağlanabilir. Yani COVID-19 süresince hem sınavına girilemediği için öğrencinin dersten başarısız sayılması hallerinde; hem de kaynak yetersizliği, çalışma ortamının uygun olmaması (aile fertlerinin hastalığı, kalabalık aile vb.) gibi sebeplerle sınava girilip de başarısız olunması hallerinde, ilgili dersin GANO hesaplamasına katılmaması sağlanabilir. Salgının ortaya çıkarttığı tek engel uzaktan eğitime teknik erişimde eşitsizlikler değildir. COVID-19 döneminin ortaya çıkarttığı psikolojik durumun başarı üzerindeki olumsuzlukları, sınavlara çalışmak için herkesin eşit olanaklara ve kaynaklara sahip olmaması gibi hususlar da eğitim hakkının temel ilkelerinden biri olan firsat eşitliğini bu süre boyunca bozmaktadır. Bu olanaklarla, salgın sürecine ve uzaktan eğitime daha bütüncül, hak merkezli ve ögrencinin en yüksek menfaati çerçevesinde bir yaklaşım sergilenerek, sokağa çıkma yasakları, ücretsiz

\footnotetext{
88 Örneğin Avusturya Eğitim, Bilim ve Araştırma Bakanlığı 2020 bahar dönemini "neutrales Semester" olarak ilan etmiştir. Bkz. Österreich Bundesministerium für Bildungs, Wissenschaft und Forschung, 'Studienförderung: Sommersemester 2020 als „,neutrales Semester“’ (31 Mart 2020)<https://www.brg14.at/wpcontent/uploads/Erlass_Neutrales_Semester.pdf> erişim tarih 13 Mayıs 2020

89 Örneğin Avusturya için bkz Österreich Bundesministerium für Bildungs, Wissenschaft und Forschung Avusturya Eğitim, Bilim ve Araştırma Bakanlığı'nın sık sorulan hukuki sorular sayfası: 'Coronavirus (COVID-19): FAQ zu rechtlichen Fragestellungen (Beihilfen, Studienrecht) - Stand: 13. Mai 2020'<https://www.bmbwf.gv.at/Themen/Hochschule-undUniversit\%C3\%A4t/Aktuelles/corona/corona_faq.html > erişim tarihi 13 Mayıs 2020. Almanya'dan incelenen çeşitli üniversiteler, Erlangen Üniversitesi, Humboldt Üniversitesi, Köln Üniversitesi'dir.
} 
izinler, zorunlu işten ayrılmalar, zorunlu ve ani olarak eğitim-öğretim metodunun uzaktan yapılması gibi ağır tedbirlerin alındığı bir dönemde, "sınavlarda başarısızlık gerekçesi” öğrencinin üzerinden alınmış olacaktır. Tüm bunlar, üniversitelerin eğitim öğretim yönetmeliklerinde değişikliğe gidilerek ya da "COVID-19 Eğitim, Öğretim, Sinav Yönetmelikleri” çıkartılarak ayrıca düzenlenebilir.

İncelenen uluslararası örneklerde tüm öğrencilerin COVID-19 salgını nedeniyle okul bitirme süreleri otomatik olarak bir dönem uzatılmıştır. Aşağıda ele alınacağ 1 gibi, sınav uyuşmazlıkları ve mezuniyet koşullarına ilişkin birçok mesele gelecek aylarda Türk idari yargısının önüne fazlaca gelebilir. Bunun için Türkiye, zorunlu uzaktan eğitim dönemine ilişkin yaşanan aksaklıkları ortaya çıkartmak ve elverişsiz grupları tespit edebilmek için geniş çaplı bir anket çalışması yaparak gerekli hukuki ve idari tedbirleri geç olmadan alabilir ${ }^{90} .2547$ sayılı Yükseköğretim Kanunu'nun" "Diploma alma, ders kredilerinin hesaplanmasl, ögrencilik haklarından yararlanma ve sinavlar" başlıklı 44. maddesine COVID-19 salgını ile ilgili istisnalar eklenebilir. Örneğin 44/(c) bendindeki azami okul uzatma süreleri kayıt dondur(a)mayan, ancak dönemin koşulları gereği başarısız olan öğrenciler açısından sıkıntılı olabilir. Yine 46/(ç) bendi uyarınca katkı payı ve öğrenim ücreti alınabilmesi için geçmesi öngörülen süreler uzatılabilir ${ }^{92}$. Ülkede yeknesaklık sağlanması açısından YÖK'ün COVID-19 salgını sürecine ilişkin ilke ve hedefleri doğrultusunda üniversiteler COVID-19 Yönetmelikleri hazırlayarak eğitim-öğretim ve sınavlara ilişkin daha esnek düzenlemeler öngörebilirler. Bunlara ilaveten, üniversitelerin eğitim-öğretim yönetmeliklerinde yer alan "kayıt dondurma" hükümlerinde de sürelere ilişkin şartlar yeniden ele alınabilir. Özellikle kayıt dondurma başvurusunda süre sınırları kaldırılıp, COVID-19 salgını süresince daha esnek kayıt dondurma başvurusu imkânı tanınabilir. Tüm bunlara ek olarak görme, işitme engeli olan, 65 yaşın üstünde olan, kronik rahatsızlığı olan, hamile, vb. gibi kişilerin uzaktan eğitime erişimi konusunda da ek tedbirler alınmalıdır.

\section{C. Üniversiteye Giriş Sınavları ve Fırsat Eşitliği}

Eğitime erişimde ayrımcılık ve firsat eşitliği konusu ülkemizde büyük öneme sahip üniversiteye giriş sınavları -ya da merkezi ve ortak sınavlar- için de tartışlabilir. AİHM'nin Türkiye ile ilgili hem ayrımcılık yasağını hem de eğitim hakkını tartıştı̆̆ı Altınay-Türkiye davası ${ }^{93}$, üniversiteye girişte kat sayı hesaplaması farkı, meslek liseleri ile düz lise mezunlarının üniversiteye girişte eşit olmamaları ve meslek

\footnotetext{
90 $\mathrm{Bu}$ yönde ülkemizdeki çeşitli disiplinlerden akademisyenler tarafindan Ağustos 2020 tarihinde kadar çeşitli saha araştırmaları yapılmaya başlanmıştır.

${ }^{91}$ Kabul Tarihi: 4.11.1981, RG 6.11.1981-17506.

922547 sayılı kanuna bir geçici madde eklenerek 2019-2020 eğitim-öğretim yılı bahar dönemi ile duruma göre 2020-2021 eğitim öğretim yılı güz dönemi boyunca kanunda yer alan sınav hakkı, katkı payı yükümlülügü, mezuniyet koşulları, ilişik kesme ile ilgili tüm süreler 6 ay ya da 1 yıl uzatılabilir.

93 Altınay v. Turkey, Başvuru No. 37222/04 (ECtHR, 9 July 2013).
} 
liselilerin dezavantajlı konumu ile ilgilidir ${ }^{94}$. AİHM, eğitim konusunda devletlerin takdir marjını geniş yorumladığı için olaydaki kat sayısı değişikliğinin, eğitim seviyesini iyileştirmeye dayalı amaçla makul bir orantı içinde olduğunu belirtmiş̧tir. Yani kat sayısı değişiklikleri nedeniyle bir ihlal kararı vermemiştir. Ancak Mahkeme, başvurucunun yönelmek istediği mesleğe göre birkaç yıl önce tercih yaptığını göz önünde bulundurmuştur. Mahkeme, sınavdan bir yıl önce, idare tarafından hiçbir geçiş önlemi alınmadan kuralların değiştirilmesini, başvurucu açısından öngörülemez bir kural değişimi olarak değerlendirmiş ve bu gerekçeyle eğitim hakkı ile bağlantılı olarak ayrımcılık yasağının ihlal edildiğine ve tedbirlerin amaçlanan sonuç ile makul bir ölçülülük ilişkisi içinde olmadığına karar vermiştir ${ }^{95}$. Burada fark edilecektir ki, AİHM, üniversite giriş sınavında yapılan değişiklikleri içerik bakımından değil, bireyler açısından öngörülemez olduğu için eğitim hakkına aykırı bulmuştur ${ }^{96}$.

Söz konusu yaklaşımla bağlantılı olarak tartışılabilecek hukuki sorun, üniversiteye giriş sınavlarında son dakika yapılan kapsam, süre ve değerlendirme ölçütü gibi esaslı değişikliklerin ve sınavın ertelenmemesinin, sınavlarda firsat eşitliği ya da sağlık hakkı bakımından bir ihlal ortaya çıkartıp çıkartmayacağıdır. Bu sorun belli bir ölçüde aşağıda ele alınmış ve Almanya'da meydana gelmiş üç somut davada güncel olarak tartışılmıştır ${ }^{97}$.

Üniversite giriş sınavları ve firsat eşitliği ile ilgili Almanya'da hâlihazırda açılmış oldukça güncel (Nisan 2020) ve ilk derece mahkemesi kararları verilmiş üç uyuşmazlık bulunmaktadır. Bunlardan ilki Hessen'de Abitur olarak adlandırılan üniversiteye geçiş

\footnotetext{
Altınay v. Türkiye davası Türkiye'deki katsayı düzenlemeleri nedeniyle üniversiteye giriște mağdur olan bir öğrenci ile ilgilidir. 1998 yılında kadar iletiş̧im fakültesinde okumak üzere iletişim meslek lisesine gidenler üniversiteye giriş sınavında kendileri ile ilgili bir bölüm tercih ettiklerinde avantajlı konumdaydılar. Ancak 1998 yılında YÖK, başvurucunun katıldığı üniversiteye giriş sınavdan (1999) bir yıl önce bir genelgeyle katsayı değişikliğine giderek, düz liseye gidenlerin katsayısını 0,5 olarak belirlemiş; iletişim meslek lisesine gidenlerin katsayısını da 0,2 olarak belirlemiş̧ir. YÖK söz konusu katsayısı oranlarında değişikliğe giderken, toplumun sosyo-ekonomik koşullarındaki değişikliği göz önünde bulundurduğunu belirtmiş ve katsayı değişikliğindeki amacını, daha nitelikli gazeteciler yetiştirmek ve yükseköğretimde gazetecilerin eğitim düzeyini iyileştirmek olarak açıklamıştır. Bu arada başvurucunun Milli Eğitim Bakanlığı'na yaptığı düz liseye geçiş talebi de o dönemdeki mevzuat gereği reddedilmiştir.

95 Altınay v. Turkey (n 94) para 60.

96 Benzer şekilde belli bölümlere girilmesi için sınırlı sayı öngören düzenlemelerde de AİHM, devletlerin takdir marjını oldukça geniş yorumlamaktadır. Bkz. Jane Kotzmann, The Human Rights-Based Approach to Higher Education (Oxford University Press, 2018) 40-43.

97 Türkiye'de Danıştay 8. Dairesi de YKS tarihinin öne çekilmesine ilişkin karara karşı açılan yürütmenin durdurulması istemini reddetmiş ve YKS sınavı YÖK'ün aldığı önlemler ile 27-28 Haziran 2020 tarihinde gerçekleştirilmiştir. Makalenin yazıldığı tarihte henüz gerekçeli karar yayınlanmadığı için burada yer verilememiştir.
} 
sınavlarına bir öğrencinin yaptığı itirazdır ${ }^{98}$. Bu itiraz, öğrencinin Abitur sınavına girecek olmasının sağlığını riske atması anlamına geleceği konusundadır. Hessen Eğitim Bakanlığı, öğrencilerin yalnızca üç defa ve beşer saatlik olmak üzere sınırlı sayıda sınav için okula gelmelerini sağlık açısından tehlikeli görmemiştir ve Robert Koch Enstitüsü tarafından alınan kararlar doğrultusunda hijyen ile sosyal mesafe kurallarına uyulduğunda riskin az olduğunu belirtmiştir. Bu arada sınava yalnızca lise son sınıf öğrencileri gireceği için, herkes kendi okulunda olacaktır. Bakanlığa göre, eğitim-öğretime ara da verildiğinden okullarda yalnızca sınava girecek son sınıf öğrencileri bulunacaktır ve mesafe kuralları rahatlıkla uygulanabilecektir. Öte yandan idare mahkemesine göre, başvuru yapan öğrencinin, sağlığın mutlak olarak korunması yönünde bir talep hakkı bulunmamaktadır. Salgın nedeniyle idarenin almış olduğu tedbirler, salgın dalgasının uzun vadede ilerlemesini yavaşlatmak ve risk gruplarına giren insanları korumak içindir; hastalığın tamamen ortadan kaldırılması ya da insanları mutlak olarak hastalıktan korumak için değildir; zira bu husus mümkün de değildir ${ }^{99}$. Karar henüz ilk derece mahkemesi aşamasındadır.

İkinci ve üçüncü davalar ise Berlin’dendir. Berlin'deki ikinci dava yine benzer biçimde bir öğrencinin hastalık riski ortadan kalkmadan Abitur sınavına girmeme yönündeki talebiyle ve bu hususta geçici tedbir kararı verilmesi için açılmıştır. İdare mahkemesi bu talebi reddetmiştir. Mahkeme’ye göre, Korona-Virüs Tedbirleri Yönetmeliği’ne uygun olarak ve güncel bilimsel veriler doğrultusunda, öğrenciler en fazla 8 ila 10 kişilik sınıflarda ve aralarında iki metre olacak şekilde sınava gireceklerdir; kronik hastalığı olan ya da risk grubunda bulunan öğrencilerin ise ayrı bir tarihte sınava girmeleri sağlanacaktır. Öte yandan davacının kendisi de sınav günü gerekli kurallara uyarak hastalığın bulaşma riskini en aza indirebilir ${ }^{100}$. Üst derece mahkemesi de bu kararı onamıştır.

Berlin'de açılan üçüncü dava ise sınava hazırlık konusunda firsat eşitliğinin bozulmuş olmasına ilişkindir. Davacı, Berlin Okul Kanunu’nda yer alan “her okulun

\footnotetext{
8 Abitur sınavları üniversiteye girişte dikkate alınan üç kısımdan oluşmaktadır. İlki öğrencilerin uzmanlık dersleri, ikincisi temel dersler, üçüncüsü de lise biterken girilen yazılı ve sözlü sınavdır. Tüm bunlar öğrencinin okul hayatı boyunca gösterdiği çabasının sonunda elde ettiği başarısının bir göstergesidir. Eyaletler arasında Abitur açısından zorluk kolaylık farkı olsa da üniversiteler bunları bildiği için, ona göre davranabilirler. Almanya'nın önündeki en önemli sorun eyaletlerin salgın nedeniyle Abitur sınavları açısından aynı takvimi ve kapsamı izleyememeleri olmuştur. Şöyle ki bazı eyaletler henüz daha Almanya'da virüs vakası görülmeden Abitur sınavının hem yazılı, hem sözlü aşamasını tamamlamıştır; bazı eyaletler yalnızca yazılı aşamasını tamamlamış ve sözlü aşamasını iptal etmiştir; bazı eyaletler de takvim gereği henüz bu sınavları yapamamış ve iptal etmiştir. Bu durumda Anayasaya uygun olan her eyaletin Abitur sınavını yapmasıdır; aksi halde firsat eşitliği açısından Anayasaya aykırı durumların ortaya çıkması muhtemel görünmektedir. Bu hukuki yorumlar ve detaylı bilgi için bkz Sibylle Schwarz, 'Abschlussprüfungen während Covid-19 Pandemie - hier Abitur in Hessen' (BeckCommunity, 31 Mart 2020) <https://community.beck.de/2020/03/31/abschlusspruefungen-waehrend-covid-19-pandemiehier-abitur-in-hessen> erişim tarihi 14 Mayıs 2020.

99 Verwaltungsgericht Wiesbaden, 'Corona-Krise begründet keinen Anspruch auf Freistellung von den Abiturprüfungen' $<$ https://verwaltungsgerichtsbarkeit.hessen.de/pressemitteilungen/corona-krise-begr\%C3\%BCndet-keinen-anspruch-auffreistellung-von-den-abiturpr \%C3\%BCfungen> erişim tarih 14 Mayıs 2020.

100 Verwaltungsgericht Berlin, 'Kein Fernbleiben von schriftlicher Abiturprüfung wegen Coronagefahren (Nr. 21/20020)' $<$ https://www.berlin.de/gerichte/verwaltungsgericht/presse/pressemitteilungen/2020/pressemitteilung.922000.php > erişim tarihi 14 Mayıs 2020.
} 
öğrencisini, öğrenme şartlarından bağımsız olarak mümkün olan en iyi şekilde mezun etme sorumluluğu" olduğunu öngören hükme dayanarak, okul ve kütüphaneler kapalı olduğu için kalabalık ve gürültülü bir evde sınava çalışmak zorunda kaldığını ve bu nedenle sınavin ertelenmesini talep etmiştir. Mahkeme ise bu hükmün, öğrenciye kişisel bir talep yetkisi vermediğini belirterek talebi reddetmiştir. Virüs nedeniyle alınan önlemler ve öğrencilerin evlerde çalışmak zorunda kalması herkesin katlandığ 1 bir durumdur. Öte yandan yaşamın diğer alanlarında olduğu gibi, sınavlara hazırlık açısından da kişiler için tamamen aynı şartların varlığının sağlanması mümkün değildir. Bununla birlikte Berlin'de Abitur sinavlarının yapılmas1, objektif olarak Almanya genelinde Abitur sınavlarının yapılmasında bir ayrım ortaya çıkmaması için, Federal Eğitim Bakanlığı tarafından eyaletlerle birlikte alınmış ortak bir karara dayanmaktadır ${ }^{101}$. Davacı temyize gitmiş ve yüksek mahkeme bu kararı onamıştır. Yüksek mahkeme yine de salgının, öğrenciler arasında daha önceden var olan sosyal ve maddi eşitsizlikleri daha da pekiştirdiğinde hem fikirdir. Ancak, var olan eşitsizlikler nedeniyle davacının içinde bulunduğu koşullar, sınavı yapacak idareye isnat edilebilir olmadığından hukuki dayanaktan yoksundur. Yüksek mahkemeye göre, uyuşmazlığın konusu olan sosyal eşitsizlikler nedeniyle ortaya çıkan eğitimde firsat eşitsizliği, sinav hukuku kapsamında alinacak acil hukuki tedbirlerle giderilebilecek nitelikte değildir. Eğitimde firsat eşitliği gibi tedbirler yasa koyucunun kendi yetki alanı içinde düzenleyeceği hususlardır. Yine yüksek mahkemeye göre, öğrencinin somut yaşam koşullarını dikkate alan bireysel bir sınava hazırlık süreci, sınav otoriteleri tarafından belirlenebilecek ve garanti altına alınabilecek bir husus değildir ${ }^{102}$.

Tüm bu kararlarda dikkati çeken özellik, Almanya'nın federal bir devlet olması ve üniversiteye girişin ülke genelinde eşitlik içinde yürütülebilmesi için Abitur sınavlarının her eyalette yapılmasının sağlanmasıdır. Kanımızca Alman idare mahkemeleri, önlerine gelen bu uyuşmazlıkların emsal teşkil edip, benzer konuda daha çok dava açılmasını önlemek için de bu yönde karar vermiş olabilirler. Alman Federal Anayasa Mahkemesi'nin Abitur sinavı ile ilgili 2017 tarihli kararında, Abitur sınavının bir öğrencinin başarı potansiyelini ölçen ve gelecekteki üniversite başarısı açısından ampirik veri ile desteklenmiş en elverişli sınav olduğu belirtilmektedir ${ }^{103}$. Almanya açısından, 2020-2021 yılı üniversite yerleştirmelerinin eşitlik içinde sağlanabilmesi için, Abitur sınavlarının tüm ülkede yapılmış olması oldukça önemlidir ${ }^{104}$. Bu husus yukarıdaki mahkeme kararlarında da dikkati çekmektedir.

\footnotetext{
101 Verwaltungsgericht Berlin, 'Keine Verschiebung der Abiturprüfung wegen erschwerter Vorbereitung (Nr. 22/2020'<https:// www.berlin.de/gerichte/verwaltungsgericht/presse/pressemitteilungen/pressemitteilung.922898.php> erişim tarihi 14 Mayıs 2020; detaylı gerekçe de buradan okunabilir.

102 Oberverwaltungsgericht Berlin-Brandenburg, 'Berliner Abiturprüfungen können fortgesetzt werden $-17 / 20$ ' $<$ https://www berlin.de/gerichte/oberverwaltungsgericht/presse/pressemitteilungen/2020/pressemitteilung.923794.php> erişim tarihi 14 Mayis 2020.

103 Bundesverfassungsgericht, 1 BvL3/14,19Dezember2017<https://www.bundesverfassungsgericht.de/e/ls20171219_1bvl000314 html $>$ erişim tarihi 14 Mayıs 2020.

104 Bu hukuki yorum için bkz Schwarz (n 98).
} 
Neler Yapılabilir? Türkiye'de de benzer talepler söz konusu olabilir. Bu açıdan ülkemizde yapılması planlanan üniversiteye ve liseye giriş gibi toplu ve merkezi sınavların çok ciddi önlemler alınarak organize bir biçimde yürütülmesi gerekecektir. Öte yandan özellikle risk grubunda olan kişiler ve sağlık durumu özellik arz eden kişiler durumlarını önceden idareye bildirecektir. Bu hususlar zaten sinav kılavuzlarında detaylı bir biçimde yer almaktadır. Ortaya çıkması muhtemel uyuşmazlık, sınav esnasında hastalık taşıyanların tek başına ayrı bir odada değil de, maske takarak diğer adaylarla birlikte aynı sınıfta sınava girmesi durumudur. Burada diğer adaylar sınav süresince maske takmadığından, maske takanlar açısından sınav koşullarında eşitsizlik ortaya çıkacaktır; bu nedenle bu kişilerin de maskesiz olabilecekleri ayrı bir odanın önceden hazırlanması gerekecektir. Yine, sınav sınıflarında bulunacak azami öğrenci sayısı, aralarındaki sosyal mesafe gibi hususların hastalıkla ilgili güncel bilimsel veriler doğrultusunda düzenlenmiş olması gerekmektedir. Sınav esnasında, sınavın sağlıklı ve her aday için eşitlik içinde geçmesinden sınav idaresi sorumludur. Türkiye'de yapılacak olan üniversiteye giriş sınavlarının tarih, süre ve kapsam değişiklikleri, içinde bulunulan öngörülemez durum nedeniyle, ulaşılmak istenen amaçla orantılı tedbirlerdir ve haklı görülebilir ${ }^{105}$. Firsat eşitliği talepleri ise içinde bulunduğumuz koşullar göz önünde bulundurularak, idare açısından sınava hazırlık süreci bakımından değil, sınav süresince yapılan uygulamalar kapsamında önem arz ettiğinden, sınavın uygulanması, sınav salonlarının koşulları, sınav oturumları arasındaki koşullar gibi hususlarda özenli olunması gerekmektedir. Bu gibi hususlarda idare güncel bilimsel veriler doğrultusunda hastalığın sınav nedeniyle yayılma riskini en aza indirecek tedbirleri almazsa, ya da önceden kronik rahatsızlıkları olan ve bunu idareye sınavdan makul bir süre önce bildiren kişiler için onlara uygun sınav odası hazırlamazsa, kusur sorumluluğu gündeme gelebilecektir. Sınav hukukuna hâkim olan firsat eşitliği, "birbiriyle klyaslanabilir adayların, mümkün olduğunca kıyaslanabilir sınav koşullarına ve ölçme-değerlendirme koşullarına tabi olması" anlamina gelmektedir ${ }^{106}$.

\section{Okul Sağı̆ğı Hizmetleri ve Sağlığa İlişkin Bilginin Gizliliği}

Doğrudan güncel salgın olgusuyla ilgili olmamakla birlikte, tehlikeli olan ve bulaşma riski taşıyan hastalıklar -ve ileride de COVID-19 hastalığ1-, genel olarak okulların ya da yükseköğretim kurumlarının kendi bünyesinde yer alan sağlık görevlilerinin sorumlulukları ile ilgili hukuki meseleleri ortaya çıkartabilir. Sağlık ve eğitim-öğretimin birleştiği bu konular daha çok öğrencilerin sağlık durumları ile bilgi sahibi olan okul doktorunun ya da hemşiresinin ${ }^{107}$, okulda rehberlik veya psikolojik

\footnotetext{
105 Ancak ülkemizde üniversite sınavının önce 25-26 Temmuz 2020 tarihinde yapılacağı açıklanmıştır; ardından sınav 27-28 Haziran 2020’ye alınmıştır. Bu durum, öngörülemezlik nedeniyle eğitim hakkının ihlalini gündeme getirebilir.

106 Bu ifade Alman Federal İdare Mahkemesi’nin sınavlarda fırsat eșitliği tanımıdır. Bundesverwaltungsgericht, BVerwG, Beschluss vom 13.05.2004 - 6 B 25.04 < https://www.bverwg.de/130504B6B25.04.0> erişim tarihi 14 May1s 2020.

107 Okul doktorunun bulunması ülkemiz mevzuatına göre zorunlu değildir. Bu hususa aşağıda değinilmiştir.
} 
danışmanlık yapan uzmanların, sahip olduğu bilgileri açıklamaları sonucu öğrencinin okuldan uzaklaştırılması ve eğitime erişiminin engellenmesi ile ilgili hukuki sorunlardır. Örneğin ABD'de psikolojik sorunları olan ve bunları yükseköğretim kurumunun psikoloğuyla paylaşan bir öğrencinin, sonradan diğer bir öğrenciyi öldürmesi olayında, maktulün ailesi, üniversite psikoloğunun, hasta-doktor ilişkisi gizliliğini ileri sürerek, öğrencinin durumu ile ilgili olarak kendilerini uyarmaması nedeniyle okul idaresine karşı dava açmış; Eyalet Yüksek Mahkemesi, okul sağlık personelinin "uyarma yükümlüğüne" atıf yaparak davacıyı haklı bulmuştur ${ }^{108}$. Buna ek olarak, HIV veya Hepatit B/C gibi tehlikeli ve bulaşma riski taşıyan hastalıklara yakalanan öğrencilerin tıbbi bilgilerinin okul sağlık personeli tarafından ilgili kişilerle paylaşılmasının, hasta olan öğrenciler açısından eğitim hakkına bir müdahale teşkil edip etmeyeceği konuları da tartışılmaktadır. Bu husustaki genel yaklaşım okul sağlık personelinin, merkezi idaredeki -sağlık bakanlığı vb.- yetkili uzman kişilerle güncel tıbbi gelişmeler doğrultusunda yapılacak istişareye göre hareket etmesidir. Öte yandan herhangi bir belirti göstermeyen ancak HIV virüsü taşıyan çocukların okula devam etmesi gerekliliği ABD'de çok sayıda yargı kararıyla açıklığa kavuşmuştur. $\mathrm{Bu}$ konudaki genel kural, öğrencinin HIV virüsü taşıdığ 1 bilgisinin yalnızca, öğrenciye yardım edecek ve öğrenciye fayda sağlayacak kişilerle ve bu amaçla paylaşılabileceğidir ${ }^{109}$.

Sağllğa ilişkin bilgilerin gizliliği hususu AİHM nezdinde de AİHS'nin özel ve aile hayatına saygı hakkını düzenleyen 8 . maddesi kapsamında değerlendirilmektedir ${ }^{110}$. Kişinin sağlı̆̆ ile ilgili bilgileri Sözleşme kapsamında "özel hayat" alanına girmektedir. AİHM'ye göre, gizliliğin korunması yönünde yasal bir garanti söz konusu olmadığı zaman, kişiler sağlikları ile ilgili önemli bilgileri vermekten ya da tamamen sağlık hizmeti almaktan kaçınabilirler ki, bu durumda yalnızca kişinin kendisi değil toplum sağlığı da tehlike altında olacaktır. Bu açıdan kişilerin sağlık bilgisinin gizliliği Mahkeme’ye

108 Olay Kaliforniya Eyaleti'nde ve Kaliforniya Üniversitesi'nde 1976 yılında yaşanmıştır. Supreme Court of California, Tarasoff v. Regents of University of California, 17 Cal. 3d 425 (Cal. 1976). Olayda psikolog okul idaresine ve kampüs polisine haber vermiş ancak öldürülme tehlikesi olan öğrenci ve ailesine haber vermemiştir. Okul idaresi de kampüs polisine, psikolojik sorunları olan öğrenciye bir kliniğe gitmesi konusunda yardımcı olmasını söylemiştir. Kampüs polisi öğrenci ile görüşerek, öğrencinin makul davrandığını görmüş ve öğrenciyi yalnızca kurbandan uzak durması yönünde uyarmıştır. Ardından öğrenci diğer kişiyi öldürmüştür. Yargılama Eyalet Yüksek Mahkemesi’ne kadar gitmiş ve nihayetinde ilgili yargı yeri, söz konusu olay açısından "uyarma yükümlülüğünün (duty to warn)" hasta-hekim ilişkisi gizliliğinin istisnası olduğuna hükmetmiştir. Bu yargılama sonucu “uyarma yükümlülüğü” ABD’nin birçok eyaletinde yasalara alınmıştır. Ancak yargı yerleri bu hususları somut olay nezdinde ayrı ayrı tartışmaktadır. Burada elbette gizliliğin konusu da önemlidir. ABD yargı yerleri, gizlilik konusu olan bilginin başkaları için tehlike oluşturup oluşturmadığını her somut olaylar nezdinde ayrıca değerlendirmektedir. Ayrıntılı bilgiler için bkz Nadine C. Schwab, Mary H. B. Gelfman (eds) Legal Issues in School Health Services (Sunrise River Press, 2005) 276-277.

109 ibid 275. ABD'deki ilgili dava listeleri ve HIV bilgisinin gizliliği ile ilgili eyalet yasaları örnekleri için bkz ibid.

110 AİHM'nin 8. maddesi ile ilgili olarak ele aldığı konular ve kararlar listesi için bkz Council of Europe/European Court of Human Rights, 'Guide on Article 8 of the European Convention on Human Rights Right to respect for private and family life, home and correspondence’ (2020). 
göre hayati önem taşıyan bir haktır ${ }^{111}$. AİHM, sağlik bilgisinin korunması ve bu hakka yapılan müdahalelerin hukukiliğini $\ddot{u}$ ļ̈ teste tabi tutmaktadır. Bunlar, sınırlamanın yasa ya da düzenleyici bir işleme dayanması ya da yasallık şartı, sınırlamanın meşru bir amaca dayanması ve sınırlamanın demokratik toplum gereklerine uygun olmasıdır. Mahkeme burada meşru amaçla sınırlama arasında da ölçülülük aramaktadır; ölçülülük de demokratik toplum gereklerine göre belirlenecektir ${ }^{12}$. Bir başka ifade ile bir kişinin sağlık bilgisinin gizliliğinin korunması hakkına yapılan müdahale, kamu sağlığı, kişinin kendi sağlığı ya da hastane personelinin sağlığı ve güvenliği gibi daha ağır basan bir gerekçe ile haklılaştırılabiliyorsa ve müdahale ölçülü ise, 8 . madde ile uyumlu bir müdahale olacaktır ${ }^{113}$.

Neler Yapılabilir? COVID-19 salgını hızlı bulaşan küresel bir salgındır. $\mathrm{Bu}$ hususta bir öğrencinin COVID-19 taşıdığı bilgisine ulaşan okul hekiminin bunu bildirme yükümlülüğü ülkemizde bulunmaktadır ${ }^{114}$. Ancak okul idarecilerinin, öğrencilerin, var ise okul doktoru / hemşiresi gibi kişilerin sağlık bilgisinin paylaşılması hususunda dikkat etmesi gereken hususlar bulunmaktadır. Sağlık verisi 6698 sayılı Kişisel Verilen Korunması Kanunu ${ }^{115}$ uyarınca özel nitelikli veridir (md. 6). Dolayısıyla veri sorumluları, sağlık bilgisinin güvenliğini sağlayacak önlemleri almalı; öğrencilerin sağlık verileri açık ve zorunlu bir gerekçe olmaksızın üçünü kişilere açıklanmamalıdır. Bu yönde doğacak hukuki uyuşmazlıklarda gizlilik hakkına yapılan müdahaleler, olaya özgü koşullar içinde değerlendirilmek kaydıyla COVID-19'un niteliği gereği, meşru bir amaca hizmet edecektir. Öğrencinin tıbbi bilgileri ise hak ihlali ortaya çıkmaması için, kişinin menfaatini koruyacak biçimde yalnızca bilmesi gereken kişilere açıklanmalıdır. COVID-19 nedeniyle okula girişine izin verilmeyen öğrenci için, yukarıda belirtildiği gibi, okul idaresi çeşitli önlemler alarak uzaktan sınav ve eğitim uygulamalarını gerçekleştirebilir. Benzer biçimde ABD'de öğrencilerin COVID-19 taşıdıklarına ilişkin sağlı bilgisinin gizliliği hususunda çeşitli öneriler yapılmıştır. Örneğin COVID-19 taşıyan öğrencinin isminin açıklanmaması ve gereğinden fazla bilginin verilmemesi gerekmektedir ${ }^{116}$.

111 Zv. Finland, Başvuru No. 22009/93 (ECtHR, 25 February 1997) para 95. AİHM sağlık bilgisinin gizliliğinin önemini Z-Finlandiya davasında vurgulamış; bu yorumuna diğer kararlarında da atıf yapmıştır. Finlandiya'da doktorlara ve psikiyatristlere, hastanın onayını almadan sağlık bilgilerini yürütülmekte olan bir ceza soruşturması dosyasına sunma yetkisi veren mevzuat gereğince, sağlık bilgisi soruşturma dosyasına sunulan HIV pozitif olan bir mahkûmun yaptığı başvuruda AIHH, 8. maddenin ihlal edilmediğine hükmetmiştir. Ancak Mahkeme, sağlık bilgisinin gizliliğinin ilke olarak önemini bu davada vurgulamıştır. AİHM benzer biçimde Y-Türkiye kararında, sağlık bilgisi nedeniyle insanların dışlanabileceğini, onur kırıı muameleye maruz kalabileceğini ve hem kendilerinin hem de ailelerinin sosyal hayatları ile iş yaşantılarının devam edemez hale gelebileceğini belirterek sağlı bilgisinin gizliliğinin önemini vurgulamıştır. Yv. Turkey, Başvuru No. 648/10, (ECtHR, 17 February 2015) para 68.

112 Doğan (n 75) 805, 806

$113 Y$ v. Turkey (n 111) para 78. AİHM, Y-Türkiye davasında, HIV pozitif olan hastanın sağlık bilgisinin hastane personeli ile gerekli tedbirleri alabilmeleri için paylaşılabileceğini, ancak böylesine hassas ve hasta açısından ciddi sosyal sorunlara yol açabilecek nitelikte bilginin amacı dışında kullanılmaması ve yayılmaması için gerekli tüm önlemlerin de alınması gerektiğini belirtmiştir. ibid para 79 .

114 Bulaşıı Hastalıkların İhbarı ve Bildirim Sistemi Hakkında Tebliğ, RG 06.11.2004-25635.

115 Kabul Tarihi: 24.3.2016, RG 7.4.2016-29677.

116 The School Superintendence Association, 'Student Privacy During the COVID-19 Pandemic' (20 March 2020) $3<$ https:// iapp.org/media/pdf/resource_center/fpf_student_privacy_during_covid_19_pandemic.pdf $>$ erişim tarihi 15 Ağustos 2020. 
Ülkemizde okul sağlık hizmetleri zorunlu değildir ve ilgili mevzuattan anlaşıldığı üzere bu husus okul idarelerinin takdirindedir. Oysa öğrencilerin sağlığ1 okulda geçirdikleri süre içinde de korunmalıdır; sağlıklı öğrenciler yetiştirmek eğitimin amaçları kapsamında değerlendirilmektedir ${ }^{117}$. Bu açıdan okulun temiz ve öğrenime elverişli (sıcaklık, nem, hijyen vb.) olmasının yanı sıra okullarda öğrenciler için koruyucu hekimliğin de yaygınlaştırılması gerekmektedir ${ }^{118}$. Okul öncesi ve ilköğretim için okulda doktor bulunması ile ilgili herhangi bir hüküm mevzuatta yer almamaktadır. Yalnızca revir hizmetlerini yürütmek üzere hemşire çalıştırılabileceğinden söz edilmektedir (Millî Eğitim Bakanlığı Okul Öncesi

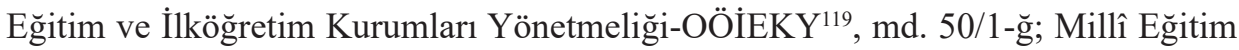

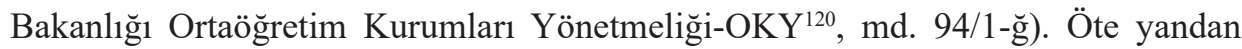
OKY'de öğrenci okul ve disiplin kuruluna "varsa okul doktoru"nun da katılacağ 1 düzenlenmektedir (OKY, md. 185/6).

2016 yılında Milli Eğitim Bakanlığı ile Sağlık Bakanlığı arasında "Okul Sağlığı Hizmetleri İşbirliği Protokolü” düzenlenmiştir. Buna ek olarak henüz TBMM'nin komisyon aşamasında olan, Milli Eğitim Temel Kanunu'nda değişiklik yapılmasını ve okullarda en az bir sağlı personeli çalıştırılması zorunluluğunu öngören bir yasa teklifi bulunmaktadır ${ }^{121}$. Her okulda en az bir sağlık görevlisi bulundurulması oldukça önemlidir. Bu hususta mevzuat eksikleri mutlaka giderilmelidir. Yükseköğretim kurumlarındaki sağlık konusu ise Yükseköğretim Kurumları Mediko-Sosyal Sağlık, Kültür ve Spor İşleri Dairesi Uygulama Yönetmeliği'nin 11. maddesinde yer almaktadır ${ }^{122}$. Sağglığa ilişkin bilginin gizliliği burada görev yapan sağlık uzmanları açısından da geçerlidir.

\section{Ulusal Hukuk Doktrini Kapsamında ve Salgın Nedeniyle Tartışılması Gereken Eğitim Hakkı Meseleleri}

Ulusal hukuk kapsamında tartışılması gereken hukuki problemler "kamu düzeni”" kavramının içeriği, eğitim-öğretim kurumlarında bulunan kişiler açısından tehlikeli salgın hastalık kapsamında idarenin sorumluluğu ve sınav hukuku problemleridir. Her şeyden önce Türkiye'de eğitim-öğretim mevzuatı idareye oldukça geniş takdir yetkisi

\footnotetext{
17 Pelin Taşkın, 'Okul Yönetiminde Öğrenci İşleri’ içinde Uğur Akın (ed) Türk Eğitim Sistemi ve Okul Yönetimi (2. Bası Pegem Akademi, 2016) 292.

118 ibid. Aynı zamanda bkz Millı̂ Eğitim Bakanlığı Okul Öncesi Eğitim ve İlköğretim Kurumları Yönetmeliği, md. 78/1-a ve b. RG 26.07.2014-29072.

119 (n 47).

120 (n 48).

121 24.12.2019, Milli Eğitim Temel Kanununda Değișiklik Yapılmasına Dair Kanun Teklifi; Dönem/Y. Yıl: 27/3; Esas No:2/2119; “Teklif ile; Milli Ĕ̆itim Bakanlı̆ğ'na bağll resmi ve özel ilköğretim ve ortaögretim kurumlarında, sağglkl ve güvenli eğitim ve ögretim ortamını sağlamak, okul içinde meydana gelen kaza ve yaralanmalara acil müdahale etmek, ilkyardım ile önleyici ve koruyucu sağllk hizmetleri vermek üzere en az bir sağllk personelinin çalıştırılmas öngörülmektedir."

122 Okul sağlığı ve rehberlik hizmetleri konusunda bkz Taşkın (n 117) 290, 293.
} 
tanıyan ve kimi zaman öngörülebilirlĭgi ortadan kaldıracak düzeye varan bir yapıya sahiptir ve eleştirilmektedir ${ }^{123}$. Olağanüstü durumlarda eğitim-öğretime ara verilmesi kararı, 5 Mayıs 2020 tarihli OÖEİKY'nin 7. maddesinde yapılan değişiklikten önce verilmiştir. Eğitime ara verme ilk olarak hukuki dayanaktan yoksun kalmıştır ${ }^{124}$.

\section{A. Hak ve Özgürlük Temelli Kamu Düzeni Yaklaşımı}

Salgın hastalıkların önlenmesi ve bu alanda alınacak tedbirlerin tümü idarenin kamu düzenini korumaya ilişkin sorumluluklarından birisidir. Kamu düzeni ise, liberal demokratik devletlerde kendi başına bir amaç olarak ele alınmamakta, "özgürlüklerin bir arada var olabilmesinin bir aracı" anlamına gelmektedir ${ }^{125}$. "Düzen" kavramı, toplumun soyut olarak istenilen biçime dönüştürülmesini ifade etmez; aksine özgür insanların biçimlendirdiği bir dünyanın ahenk içindeki işleyişini ifade etmektedir ${ }^{126}$. Bu açıdan özgürlükler, kamu düzeninin bir unsurudur ve kamu düzeninin amaçlarından bir tanesi de özgürlüklerin korunmasıdır ${ }^{127}$. Bununla birlikte insan onurunun korunması da kamu düzeninin kapsamındadır ${ }^{128}$. Demokratik ve insan haklarına saygılı devletlerde idareye tanınan takdir yetkisinin amacı, idarenin tekil ve önceden öngörülemeyen durumlar karşısında hakkaniyeti sağlayarak insan haklarını daha etkin koruması ile açıklanmaktadır ${ }^{129}$. Bu açıdan kamu düzeni kavramına hak ve özgürlükler temelli yaklaşmak gerekmektedir.

İnsan haklarının gerçekleştirilmesi ve korunması için günümüzde artık gerek kuşaklara dayalı anlayış, gerekse hakların statülere göre farklılaşan koruma rejimlerine sahip olması etkilerini yitirmektedir. İnsan hak ve özgürlükleri açısından asıl önemli olan, haklara veya yükümlülüklere ilişkin herhangi bir sınıflandırma sisteminin, hakların gerçekleştirilme ve koruma düzeylerinde herhangi bir farklılığ meşrulaştırmak için kullanılmamasıdır ${ }^{130}$. Bir başka ifade ile devletin mali kaynaklarının yeterliliği ölçütüne bağlanan ekonomik, sosyal ve kültürel haklar ile medeni ve siyasi haklar arasında devletin üstlendiği yükümlülüklerin niteliği bakımından kesin ayrımlar artık yapılamamaktadır ${ }^{131}$. Bu nedenle COVID-19 salgınının ortaya çıkarttığı eğitim hukuku meselelerinde, kaynakların yeterliliği bir sınır olarak ileri sürüldüğünde, eğitim hakkının sınırlandırılmasında ölçülülük ilkesine

\footnotetext{
23 Tolga Şirin, 'Tehlikeli Salgın Hastalıklarla Hukuksal Mücadeleye Anayasal Bir Giriş' (2020) 9 (17) Anayasa Hukuku Dergisi 129 .

124 ibid 128-129.

125 Özge Okay Tekinsoy, İdare Hukukunun Kavramı Olarak Kamu Düzeni (On İki Levha Yayıncılık, 2011) 37.

126 ibid 37.

127 ibid.

128 Aslı Şimşek, Genel Kamu Hukukunun Temel Kavramı Olarak Kamu Düzeni (Turhan kitabevi yayınları, 2012) 61.

129 Dilşat Yılmaz, 'Alman İdare Hukukunda İdarenin Takdir Yetkisi ve Takdir Yetkisinin Yargısal Denetimi' (2011) 69 İstanbul Üniversitesi Hukuk Fakültesi Mecmuası 1020.

130 Bülent Algan, Ekonomik, Sosyal ve Kültürel Hakların Korunması (Seçkin Yayınları, 2007) 91.

131 ibid 92.
} 
aykırı sonuçlar ortaya çıkabilir ${ }^{132}$. Nitekim, ani gelişen olaylar, önemli kazalar, doğal afetler ya da terör eylemleri gibi olaylar karşısında, idarenin hem risklerin önlenmesi için gerekli tedbirlerin alınması sorumluluğu, hem de meydana gelecek zararın azaltılması için gerekli örgütü kurma yönünde bir sorumluluğu bulunmaktadır ${ }^{133}$.

Türk hukuk sisteminde eğitim ve yükseköğretime ilişkin meseleler ve uyuşmazlıklar temelde idare hukukunun, vakıf üniversiteleri ya da özel okullar söz konusu olduğunda da, iş hukuku, borçlar hukuku ya da ticaret hukukunun bakış açısı ile ele alınmaktadır ${ }^{134}$. Ancak özellikle hak ve özgürlük söz konusu olduğu için eğitim alanındaki eylem ve işlemleri teknik birer idari eylem ve işlem olarak görmek, ya da eğitimsel ilişkileri sözleşmelere dayalı ilişkiler çerçevesinde değerlendirmek, kimi durumlarda etkin bir koruma sağlanamamasına yol açmaktadır ${ }^{135}$. Bu nedenle eğitimöğretim alanındaki her uyuşmazlıkta temel hareket noktası eğitimin birey ve toplum için anlamı ve önemi olmalıdır. Buna ek olarak, eğitim olgusu, okulların kurulup düzenlenmesi ve iç işleyişi, müfredatın belirlenmesi ve uygulanma biçimleri, eğitimöğretim kurumunda çalışan eğitimciler ve öğretmenlerin hak ve yükümlülükleri, çalışma koşulları, okul-aile-öğrenci ilişkileri, sınavlarla ilgili her türlü husus ve beslenme dahil birçok eylem ve işlemi kapsamaktadır.

\section{B. İdarenin Eğitim-Öğretim Kurumlarındaki Faaliyetler Kapsamında COVID-19 Salgını Nedeniyle Oluşacak Zararlardan Sorumluluğu}

Eğitim-öğretim alanında COVID-19 ile bağlantılı hukuki meseleler, ulusal hukuk doktrininde idarenin sorumluluğu açısından idari yarg1 yerlerinin önüne gelebilir. $\mathrm{Bu}$ açıdan, idarenin sınava katılanların sağlığını korumak üzere sınavların iptal edilmesi gibi bir yükümlülüğün olup olmaması ya da merkezi sınavlarda bulunması zorunlu sınav görevlilerinin görevleri nedeniyle ve görevin ifası sırasında COVID-19 hastalığına yakalanmış olmalarından (ve hatta ardından evdeki yaşlı ya da hastalara da bulaştırmış ve onların da bir zarara uğramış olmasından) doğan zararların tazmini talepleri ortaya çıkabilir. Bilindiği gibi idarenin kusur sorumluluğunun yanında kusursuz sorumluluğu da bulunmaktadır ve özellikle kusursuz sorumluluk konusunda sosyal risk ilkesinin kapsamının salgın hastalıkları da içine alacak biçimde giderek genişlediği savunulmaktadır ${ }^{136}$. 1968 tarihli Fransız Danıştayının,

Şirin (n 123) 77: “... [Anayasanın 65. maddesinde yer alan] 'bu görevlerin amaçlarına uygun öncelikleri gözeterek' ibaresi aslında mali kaynaklar ile öncelikler arasında özel bir ölçülülük biçimini vurgulamaktadır.” Bkz. Dilşad Çiğdem Sever, 'Sağlık Kamu Hizmetinin Örgütlenmesi ve Özelleştirme Biçimleri', içinde Özge Yücel ve Gürkan Sert (eds), Sağllk ve Tip Hukukunda Sorumluluk ve Insan Hakları (Seçkin Yayınları 2018) 95 vd.

133 Okay Tekinsoy (n 125) 68.

134 Dilşad Çiğdem Sever, 'Bir Kamu Kurumu Olarak Vakıf Üniversiteleri ve Bu Üniversitelerde Çalı̧an Akademisyenlerin Hukuki Statüsü’ (2016) Mart Legal Hukuk Dergisi 1181.

135 Bunun en dikkat çekici örnekleri özel okul, kreş, gündüz bakımevi ile devlet okulları, anaokulu gibi aynı nitelikte eğitim sunan ancak farklı yasalara tabi olan kurumlardır.

136 Hasan Nuri Yaşar, ‘İdarenin Sorumluluğu Üzerine Düşünceler’ (2008) 66 İstanbul Üniversitesi Hukuk Fakültesi Mecmuası 218. 
eğitim kurumlarında salgın hastalık konusunda sıklıkla atıf yapılan, kızamık salgını sirasında okulda hastalık kapan hamile bir öğretmenin uğradığ zarardan idarenin sorumlu olup olmadığına ilişkin bir kararı bulunmaktadır. Olayda, anne öğretmen okulda icra ettiği mesleği sırasında kızamık kapmış ve anne karnındaki bebekte de bu nedenle bir takım sağlık problemleri meydana gelmiştir. Fransız Danıştayı, burada bebeği üçüncü kişi olarak değerlendirip, onun uğradığ1 zarar bakımından idarenin kusursuz sorumluluğuna hükmetmiş; ancak annenin ise görevi gereği okulda bulunduğunu ve bu nedenle karşı karşıya kaldığı risk nedeniyle kızamık hastalığına yakalandığını ve bunun sosyal güvenlik sistemiyle karşılandığını; bu nedenle kusursuz sorumluluğun anne öğretmenin hastalanması bakımından söz konusu olmayacağını belirtmiştir. Öte yandan anne ve babanın bebeğin sağlık problemleri ile birlikte doğmasından kaynaklanan kayıplarını ise idarenin kusursuz sorumluluğu kapsamında değerlendirmiştir ${ }^{137}$. Türk hukukunda Danıştay, mesleki riskler bakımından ortaya çıkan zararlarda kusursuz sorumluluk esasını uygulamaktadır ${ }^{138}$.

İdarenin sorumluluğunu ortadan kaldıran nedenler arasında konumuz açısında, zarar görenin davranış1, üçüncü kişinin davranışı ve mücbir sebep tartışmaları ortaya çıkabilir. Örneğin idare sınavların yapılması için güncel bilimsel veriler doğrultusunda alması gereken bütün önlemleri almasına rağmen, zarar gören bu tedbirlere uygun davranmadığ 1 için zarar görmüşse, idari eylem ile zarar arasındaki illiyet bağı kopabilir ve idarenin sorumluluğuna hükmedilmeyebilir ${ }^{139}$. Bu açıdan özellikle önceden risk grubunda bulunan ve kronik bir rahatsızlığı olan öğrenciler ile eğitim-öğretim personelinin, sınav mekânında bulunmaktan ötürü zarar göreceğini açıklayarak, durumlarını ilgili deliller ile birlikte mutlaka sınavdan makul bir süre önce idareye bildirmeleri gerekecektir ${ }^{140}$. Bu durumda idare onlara yönelik tedbirler alabilir. Benzer şekilde okullar açıldığında ve COVID-19 salgını devam ettiğinde, risk grubunda olanların eğitim kurumunda bulunmaması yönünde doktor raporu alarak okula gelmemesi söz konusu olabilecektir. Ancak eğitim-öğretim ve okul söz konusu olduğunda, zarar görenin kişisel kusuru konusunda mutlaka somut olaya özgü koşullar bakımından titizlikle bir değerlendirme yapılması gerekecektir. Örneğin Danıştay, ilkokul öncesi eğitim kurumunda meydana gelen bir öğrencinin diğerinin gözünü yaralaması olayında, “...idarenin okul saatlerinde bu gözetim ve denetimi aksatmadan sürdürmek zorunda olduğu, bu sorumluluk yalnı ders saatleri ile sinırl olmayıp, okulda bulunan sürenin tamamını, bu arada teneffüs, yemek ve dinlenme aralarını da kapsadı̆̆g, bu bakımdan Milli Eğitim Kamu hizmetlerinin sadece eğitim ve öğretim yönü ile ilgili bir hizmet olmadı̆̆ı öğrencilerin gözetim ve

\footnotetext{
137 Kemal Gözler, İdare Hukuku-Cilt II (Ekin Kitabevi Yayınları, 2003) 1097.

138 ibid 1099; Ramazan Çağlayan, 'Risk İlkesi Gereğince İdarenin Kusursuz Sorumluluğu Bağlamında Sosyal Risk İlkesi' içinde Sorumluk ve Tazminat Hukuku Sempozyumu-2009, 467.

139 Ender Ethem Atay, İdare Hukuku (2. Bası Seçkin Yayınları, 2019) 336.

140 Bu konuda Almanya'daki çeşitli üniversitelerin eğitim-öğretim ve sınav yönetmeliklerine ekleme yaptığı görülmektedir veya matbu dilekçeler oluşturmuş̧lardır.
} 
denetimini de içeren bir kamu hizmeti olduğunu kabul etmek gerektiği, olayda bu hizmetin kötü işlediği, tazminat konusu zararın oluşum biçiminden anlaşıldığg, okul bahçesinde idarenin sorumluluğu altında kaldığı..."yönünde bir değerlendirmede bulunmuştur ${ }^{141}$. Bu açıdan okullardaki sosyal mesafe kurallarına uyulmasından, somut olaya özgü koşullar değerlendirilmek kaydıyla, okul idarelerinin sorumlu olabilmesi gündeme gelebilir. Ancak yine de somut olaya özgü koşullar belirleyici olacaktır.

Yukarıda -önemli kazalar, doğal afetler, vb.- ani gelişen olayların, idarenin, hem risklerin önlenmesi için gerekli tedbirlerin alınması sorumluluğunu, hem de meydana gelecek zararın azaltılması için gerekli örgütü kurmak biçimindeki sorumluluğunu doğuracağ nedeniyle illiyet bağı kopabilir ve idarenin sorumluluğu ortadan kalkabilir. Mücbir sebep nedeniyle idarenin sorumluluğunun ortadan kalkmasında ise, ilgili olayın veya sonuçlarının öngörülemez ve önlenemez olması önemlidir ${ }^{143}$. COVID-19 özelinde bir değerlendirme yapılırsa, hastalığın havadan damlacık yoluyla kolaylıkla bulaşabiliyor olması nedeniyle, idarenin insanların hepsinin birden hasta olmamasını sağlaması mümkün değildir. Bunun için bütün ülkenin evden çıkmaması ve her türlü hizmetin durması gerekecektir ki böylesine bir durum gerçekçi değildir. Kanımızca idarenin sorumluluğu COVID-19 hastalı̆̆ının yayılmasını mümkün olduğu ölçüde yavaşlatmak, kontrol altına almak ve özellikle risk grubuna giren kişileri hastalıktan korumak ve bu yönde tedbirler almaktır. Bu nedenle idare, eğitim-öğretim kurumlarında hastalığın yayılma hızını yavaşlatmak için gerekli her türlü tedbiri öncelikle almalıdır. Bu hususları tam olarak yerine getirmediğinde kuşkusuz idarenin hizmet kusuru söz konusu olacaktır.

Eğitim-öğretim alanında idarenin kusursuz sorumluluğu kamu külfetleri karşısında eşitlik ilkesi kapsamında da tartışılabilir ${ }^{144}$. Kamu külfetleri önünde eşitlik ilkesi, idarenin hukuka uygun eylemleri neticesinde, kamuya sağlanacak bir yarar nedeniyle, birey aşırı bir külfet altında kaldığında, bu külfetin denkleştirilerek, kişinin uğradığı zararın idare tarafından karşılanmasını gerektirmektedir ${ }^{145}$. Bir başka ifade ile, idarenin hukuka uygun eylemi, söz konusu kişiden özel bir fedakârlık mı gerektiriyor? İşte burada söz konusu olan, özel fedakârlıkta bulunan kişiye diğerlerine kıyasla eşit / adil davranılmamış olmasıdır. Bu eşitsizlik, kamuya bir yarar

\footnotetext{
141 Danıştay 8.D., E: 1987/539, K: 1988/690, KT: 13.10.1988.

142 Okay Tekinsoy (n 125) 68.

143 Atay (n 139) 378, 379.

144 Kavrama yönelik tartışmalar için bkz Yaşar (n 136) 209, 2010.

145 Atay (n 139) 415, 416. "[Kamu külfetleri karşısında eşitlik ilkesi] Genel, soyut, objektif düzenlemeler yapan kanunların bireyleri zarara uğratması halinde devletin sorumluluğu kabul edilmemektedir."

Kusursuz sorumluluk ile ilgili Türk idare hukukunda belli bir sistemin kabul edilmediğine ilişkin değerlendirme ve kusursuz sorumluluk ile ilgili güncel kararlar için bkz Celal Işıklar, 'Danıştay Kararlarında İdarenin Kusursuz Sorumluluğunu Kaldıran ve Azaltan Haller’ (2019) 1 Yıldırım Beyazıt Üniversitesi Hukuk Fakültesi Dergisi 121.
} 
sağlamak için ve hukuka uygun olarak ortaya çıkmıştır; bu nedenle tüm kamunun bu külfete ortak olması gerekir ${ }^{146}$. Bu doğrultuda, merkezi ve ortak bir sınavda idarece alınan tüm tedbirlere rağmen yine de COVID-19 hastalığı kapan bir öğrenci ya da sınav görevlisinin zararının tazmini için, kamu külfetleri karşısında eşitlik ilkesine dayanılıp dayanılamayacağı, idari yargı yerlerinin COVID-19 salgınına atfettiği hukuki anlama göre değişebilir. COVID-19 salgını küresel bir salgın (küresel felaket) olduğu için şu anda hastalıkla mücadelede toplumun bütün kesimleri ve meslek grupları ortak fedakârlıklarda bulunmaktadır; bu nedenle zararların idarece tazmin edilmesi yönünde -olayda hizmet kusuru yok ise- yargı kararları pek olas1 görülmemektedir ${ }^{147}$; ancak bu konuda genelleme yapmak da mümkün değildir. Sonuç olarak tekil durumlar önceden tahmin edilemez. Somut uyuşmazlık iddiaları söz konusu olduğunda, idari yargı yerleri tüm bu hususları ve olaya özgü koşulları değerlendirerek karar verecektir.

\section{Sonuç}

COVID-19 salgını nedeniyle eğitim-öğretim alanında ve eğitim hakkı kapsamında tartışılabilecek hukuki sorunlar çeşitlidir. Çalışmada uluslararası örnekler incelenerek, Türkiye'de de ortaya çıkması muhtemel sorunlara ana hatlarıyla yer verilmiş̧ir. Şu bir gerçektir ki, önümüzdeki aylarda küresel bir salgın olan böylesine bir olay neticesinde hukuk sistemlerini ve özellikle de yargı yerlerini ciddi bir sınav bekliyor olacak. Öte yandan böylesine büyük çaplı bir salgın hukuk sistemimizi de gözden geçirmemiz ve eksiklikleri tamamlayıp, sorunlu kısımları düzeltmemiz için vesile olacaktır. Eğitim-öğretim alanındaki uyuşmazlıkların çözümünde eğitim hakk1 ve insan hakları bakış açısının gerekliliği önemlidir. Eğitim hakkı ile ilgili olarak ortaya çıkması muhtemel problemler aşă̆ıdaki gibi özetlenebilir:

1. Salgın hastalık da söz konusu olsa devletlerin eğitim hakkına ilişkin yükümlülükleri devam etmektedir. Eğitimde firsat eşitliği, eğitime erişim, internet, teknik altyapı vb. hususlarda hukuka aykırılıklar, ayrımc1lık, ciddi eşitsizlikler söz konusu olabilir.

146 Yaşar (n 136) 210: "Kamu külfetleri önünde eşitlik ilkesi, idari faaliyetlerle kamuya sağlanacak bir yarar dolaylsılyla ortaya çıkan zarara, bireyin kendi aleyhine, katlanmak zorunda kalmasının yarattı̆̆ adaletsizliği ortadan kaldırmayı amaçlamaktadır. Kavramı çekici kılan öncelikle "adalet" düşüncesine dayanmasıdır. Yine kamu sorumluluğunun ağırlı̆̆ının da kavrama içkin olduğunda şüphe yok. ... Yurttaşlar tarafindan finanse edilen idarenin toplum yararına faaliyet gösterirken bir gerçek veya tüzel kişiye zarar vermesi onu, diğer yurttaşlardan daha fazla mali külfete maruz bırakması demek olur. İste bu durumlarda, idare ortaya çıkan külfeti kamudan elde ettiği gelirden karşılamakla yurttaşları dolaylı biçimde külfete ortak eder. Böylece, herkes bir kamu hizmetinin ya da kamusal bir faaliyetin ortaya çıkardı̆̆g yarar ve zarardan eşit biçimde etkilenmiş olur."

147 Bu yaklaşım özellikle Almanya'da COVID-19 salgını nedeniyle katlanılmak zorunda olunan külfetlerin ya da firmaların uğradığı zararların idarece tazmin edilip edilmeyeceğine ilişkin tartışmalarda dikkati çekmektedir. Bkz. Matthias Cornils, 'Corona, entschädigungsrechtlich betrachtet' (Verfassungsblog, 13 Marz 2020) <https://verfassungsblog.de/coronaentschaedigungsrechtlich-betrachtet/> erişim tarihi 18 Mayıs 2020.

Benzer şekilde bkz 'Entschädigungen für Betriebsschließungen nach aktueller Rechtslage unwahrscheinlich' (Noerr, 9 April 2020) <https://www.noerr.com/de/newsroom/news/entschadigungen-fur-betriebsschliessungen-nach-aktuellerrechtslage-unwahrscheinlich> erişim tarihi 18 Mayıs 2020. 
2. Sınav hukuku problemleri ortaya çıkabilir. Bunlar hem merkezi ve ortak sınavlara ilişkin olabilir; hem de okullarda ve üniversitelerde yapılan sınavların her aşamasında ilişkin olabilir. Bu nedenle kanımızca Türkiye'de en büyük eksiklerden birisi sınavların hukukuna ilişkin temel yaklaşımdır. Hukukta sınav olgusuna bütünsel yaklaşacak temel bir kanuna ihtiyaç vardır.

3. Sosyal açıdan en elverişsiz grup, salgın sonucunda da daha kötü bir duruma gelmiştir. Devletlerin aldıkları önlemler ilk olarak elverişsiz ve zayıf gruplara (yoksullar, özel eğitim ihtiyacı olanlar, kronik rahatsızlı̆̆ı olanlar, yaşlılar, vb.) yönelik olmalıdır. Nitekim BM Ekonomik, Sosyal, Kültürel Haklar Komitesi, günlük beslenme ihtiyacını yalnızca devlet okulundan sağlayan en yoksulların, okullara erişimin mümkün olmadığı güncel durumda en dezavantajlı konumda olduğunu belirtmektedir ${ }^{148}$.

4. UNESCO, eğitime erişim engeli ortaya çıkmaması için yalnızca ileri-teknolojik çözümler değil, basit-teknoloji ya da hiçbir teknolojiye bağlı olmayan çözüm önerileri geliştirilmesinin, fırsat eşitliği açısından önemini vurgulamaktadır ${ }^{149}$.

5. Geleceğe yönelik olarak okullar açıldığında, eğitime erişim konusunda sıkıntı yaşayanlara odaklanılması gerekmekte, eksiklerin telafisi sağlanmalıdır. $\mathrm{Bu}$ süreçte fazladan çalışacak olan eğitim-öğretim personelinin hakları da göz önünde bulundurulmalıdır.

6. Salgın süresince daha silik görünen bir grup, çocuklu olup (diğer sektörlerde de olduğu gibi) eğitim-öğretim alanında çalışan ebeveynlerdir. Özellikle performansa dayalı ücret alınan mesleklerde ya da atama-yükselmenin belli bir performansa dayandığı durumlarda, salgın süresince çocukla evden çalışmak zorunda kalanlar açısından çeşitli düzenlemeler yapılmalı; süreler yeniden düzenlenerek, ek süreler verilmelidir.

7. Okul sağlığı konusu kurumsallaşmalı ve TBMM'de halen komisyon aşamasında olan okul doktoru ile ilgili yasa teklifi yasalaşmalıdır.

\footnotetext{
Hakem Değerlendirmesi: Dış bağımsız.

Çıkar Çatışması: Yazar çıkar çatışması bildirmemiştir.

Finansal Destek: Yazar bu çalışma için finansal destek almadığını beyan etmiştir.

Peer-review: Externally peer-reviewed.

Conflict of Interest: The author has no conflict of interest to declare.

Grant Support: The author declared that this study has received no financial support.
}

\footnotetext{
148 Statement of the Committee on Economic, Social and Cultural Rights, 'COVID-19: UN Experts call for international solidarity to alleviate financial burdens of developing countries and the most vulnerable' <https://www.ohchr.org/EN/ NewsEvents/Pages/DisplayNews.aspx?NewsID=25821\&LangID=E $>$ erişim tarihi 18 Mayıs 2020.

149 UNESCO, 'National Education Responses to COVID-19 Summary report of UNESCO's online survey' (April 2020$) 11$.
} 


\section{Bibliyografya/ Bibliography}

Algan B, Ekonomik, Sosyal ve Kültürel Hakların Korunması (Seçkin Yayınları, 2007).

Alon T et. al. , 'The Impact of COVID-19 on Gender Equality' (2020) 4 Covid Economics: Vetted and Real-Time Papers.

Antecol $\mathrm{H}$ et. al., 'Equal but inequitable: Who benefits from gender-neutral tenure clock stopping policies?’ (2018) 108 American Economic Review, 2420-2441.

Arslan Öncü G, 'Ulusalüstü İnsan Hakları Hukukunda Soruşturma Usulü' (2011)31(1) Milletleraras1 Hukuk ve Milletlerarası Özel Hukuk Bülteni 29-90.

Atay EE, İdare Hukuku (2. Bası Seçkin Yayınları, 2019).

Aybay R, Açıklamalı Insan Hakları Evrensel Bildirisi, (Türkiye Barolar Birliği Yayınları, 2006).

Cohen A, 'Women's academic journal submissions plummet amid coronavirus' (Fast Company, 1 May 2020) https://www.fastcompany.com/90499954/womens-academic-journal-submissionsplummet-amid-coronavirus > erişim tarihi 9 Mayıs 2020.

Cornils M, 'Corona, entschädigungsrechtlich betrachtet' (Verfassungsblog, 13 Marz 2020) < https:// verfassungsblog.de/corona-entschaedigungsrechtlich-betrachtet/> erişim tarihi 18 Mayıs 2020.

Çağlayan R, 'Risk İlkesi Gereğince İdarenin Kusursuz Sorumluluğu Bağlamında Sosyal Risk İlkesi' içinde Sorumluk ve Tazminat Hukuku Sempozyumu-2009 451-495.

Çelik A, ‘Avrupa İnsan Hakları Mahkemesi Kararlarında Eğitim Hakkı’ (2015) 6(20) Türkiye Adalet Akademisi Dergisi 279-328.

Davies SE and Bennett B, 'A gendered human rights analysis of Ebola and Zika: locating gender in global health emergencies’ (2016) 92(5) International Affairs 1041-1060.

Doğan İ, Insan Hakları Hukuku (3. Bası Astana Yayınları, 2019).

Dzehtsiarou K, 'COVID-19 and the European Convention on Human Rights', <https:// strasbourgobservers.com/2020/03/27/covid-19-and-the-european-convention-on-humanrights/> erişim tarihi 11 Mayıs 2020.

Elibol Brönneke Z, 'Uluslararası İnsan Hakları Sözleşmelerine Koyulan Çekinceler Çerçevesinde Hedef ve Amaçla Bağdaşma Ölçütü ve Türkiye Uygulaması' (Doktora Tezi, İstanbul Üniversitesi 2017).

Flaherty C, 'Faculty Home Work', (Inside HigherED, 24 March 2020) <https://www.insidehighered. com/news/2020/03/24/working-home-during-covid-19-proves-challenging-faculty-members> erişim tarihi 9 Mayıs 2020.

-- 'No Room of One's Own', (Inside HigherED, 21 April 2020) < https://www.insidehighered.com/ news/2020/04/21/early-journal-submission-data-suggest-covid-19-tanking-womens-researchproductivity> erişim tarih 9 Mayıs 2020.

Giannini S, 'Covid-19 school closures around the world will hit girls hardest' (UNESCO, 31 Mart 2020) <https://en.unesco.org/news/covid-19-school-closures-around-world-will-hit-girlshardest> erişim tarihi 19.05.2020.

Göçer M, Uluslararası Hukuk ve İnsan Haklarının Uluslararası Korunması, Uluslararası Hukukun İnsan Hakları Alanına Uygulanmasından Kaynaklanan Kimi Sorunlar Üzerine Karşılaştırmalı Bir Inceleme (Seçkin Yayınları, 2002).

Gözler K, Anayasa Hukukunun Genel Esasları (9. Bas1, Ekin Kitabevi Yayınları 2017). -- İdare Hukuku-Cilt II (Ekin Kitabevi Yayınları, 2003).

Groll T, 'Wer darf sein Kind in die Kita schicken?' (Zeit Online, 17 April 2020) <https://www.zeit. de/politik/deutschland/2020-04/corona-notbetreuung-franziska-giffey-kita-faq > erişim tarihi 18 Mayıs 2020. 
Haughey M et. al., 'Open Schooling', içinde Terry Evans and others (eds) International Handbook of Distance Education, (Emerald, 2008) 147-166.

Işıklar C, 'Danıştay Kararlarında İdarenin Kusursuz Sorumluluğunu Kaldıran ve Azaltan Haller' (2019) 1 Yıldırım Beyazıt Hukuk Dergisi, 115-158.

Kaplan R, 'Birleşmiş Milletler Belgelerinde Eğitim Hakkı' (2015) 6(20) Türkiye Adalet Akademisi Dergisi 329-372.

Kotzmann J, The Human Rights-based Approach to Higher Education (Oxford University Press, 2018).

Newell C, 'Distance Education: Enabling and Disabling?' içinde Terry Evans and others (eds), International Handbook of Distance Education (Emerald 2008) 87.

Olbrisch M, 'So bewerten die Bundesländer das "Corona-Halbjahr"' (Spiegel Panorama, 12 Mayıs $2020)<$ https://www.spiegel.de/panorama/bildung/schulnoten-in-der-corona-krise-so-gehen-diebundeslaender-vor-a-8a3717a6-5f0f-469b-b50c-fa50186fd466> erişim tarihi: 15 Mayıs 2020.

Okay Tekinsoy Ö, İdare Hukukunun Kavramı Olarak Kamu Düzeni (On İki Levha Yayıncılık, 2011).

Rooney J, 'European Court of Human Rights to Consider Right to Education' (Oxford Human Rights Hub, 21 Ekim 2016) < http://ohrh.law.ox.ac.uk/european-court-of-human-rights-toconsider-right-to-education/> erişim tarihi: 14 Ağustos 2020.

Schwab NC and Gelfman MHB (eds), Legal Issues in School Health Services (Sunrise River Press, 2005).

Schwarz S, 'Abschlussprüfungen während Covid-19 Pandemie - hier Abitur in Hessen' (BeckCommunity, 31 Mart 2020) <https://community.beck.de/2020/03/31/abschlusspruefungenwaehrend-covid-19-pandemie-hier-abitur-in-hessen> erişim tarihi 14 Mayıs 2020.

Spotlight: Quality education for all during Covid-19 crisis' (HundrED and OECD April 2020).

Sever DÇ, 'Bir Kamu Kurumu Olarak Vakıf Üniversiteleri ve Bu Üniversitelerde Çalışan Akademisyenlerin Hukuki Statüsü’ (2016) Mart Legal Hukuk Dergisi 1175.

Smith A and Webster F, 'Changing Ideas of the Universty' içinde Anthony Smith ve Frank Webster (eds), The Postmodern Univeristy? Contested Visions of Higher Education in Society (Open University Press 1997) 12.

Şimşek A, Genel Kamu Hukukunun Temel Kavramı Olarak Kamu Düzeni (Turhan kitabevi yayınları, 2012).

Şirin T, 'Tehlikeli Salgın Hastalıklarla Hukuksal Mücadeleye Anayasal Bir Giriş’ (2020) 9 (17) Anayasa Hukuku Dergisi 43-146.

Tan T, 'Sınav ve Jüri Değerlendirmelerinin Yargısal Denetimi’ (1996) 51(1) AÜSBFD 409.

Taşkın P, 'Okul Yönetiminde Öğrenci İşleri’ içinde Uğur Akın (ed) Türk Eğitim Sistemi ve Okul Yönetimi (2. Bası Pegem Akademi, 2016) 268.

Yaşar H N, ‘İdarenin Sorumluluğu Üzerine Düşünceler' (2008) 66 (1) İstanbul Üniversitesi Hukuk Fakültesi Mecmuası 201-220.

Y1lmaz D, ‘Alman İdare Hukukunda İdarenin Takdir Yetkisi ve Takdir Yetkisinin Yargisal Denetimi’ (2011) 69 İstanbul Üniversitesi Hukuk Fakültesi Mecmuası 1019-1032.

Zghibarta P, 'The Whos, the Whats, and the Whys of the Derogations from the ECHR amid COVID-19', erişim: https://www.ejiltalk.org/the-whos-the-whats-and-the-whys-of-thederogations-from-the-echr-amid-covid-19/; tarih:11.05.2020. 
Ziemele I and Liede L, 'Reservations to Human Rights Treaties: From Draft Guideline 3.1.12 to Guideline 3.1.5.6' (2013) 24 The European Journal of International Law 1135.

\section{BM Belgeleri ve İnternet Kaynakları}

CEDAW, 'Guidance Note on CEDAW and COVID-19' $2<$ https://www.ohchr.org/en/hrbodies/ cedaw/pages/cedawindex.aspx> erişim tarihi 19 Mayıs 2020.

Statement of the Committee on Economic, Social and Cultural Rights, 'COVID-19: UN Experts call for international solidarity to alleviate financial burdens of developing countries and the most vulnerable' $<$ https://www.ohchr.org/EN/NewsEvents/Pages/DisplayNews. aspx?NewsID=25821\&LangID=E $>$ erişim tarihi 18 Mayıs 2020 .

OHCHR, 'Covid-19 and Women's Human Rights: Guidance' (OHCHR, 15 April 2020) <https:// www.ohchr.org/Documents/Issues/Women/COVID-19_and_Womens_Human_Rights.pdf> erişim tarihi 19 Mayıs 2020.

OHCHR <https://ap.ohchr.org/documents/dpage_e.aspx?m=999> erişim tarihi 08 Mayıs 2020.

CESCR, 'General Comment No. 13: The Right to Education (Art. 13 of the Covenant)', 8 December 1999, E/C.12/1999/10.

CESCR 'General Comment No. 25 on science and economic, social and cultural rights (article 15 (1) (b), (2), (3) and (4) of the International Covenant on Economic, Social and Cultural Rights' 30 April 2020, E/C.12/GC/25.

CESCR 'Statement on the coronavirus disease (COVID-19) pandemic and economic, social and cultural rights Statement by the Committee on Economic, Social and Cultural Rights' 17 April 2020 E/C.12/2020/1.

CRC 'The Committee on the Rights of the Child warns of the grave physical, emotional and psychological effect of the COVID-19 pandemic on children and calls on States to protect the rights of children' 8 April 2020, para $3<$ https://tbinternet.ohchr.org/Treaties/CRC/Shared $\% 20$ Documents/1_Global/INT_CRC_STA_9095_E.pdf > erişim tarihi 08 Mayıs 2020.

UNESCO, 'National Education Responses to COVID-19Summary report of UNESCO's online survey' (April 2020) 11.

UNICEF $<$ https://www.unicef.org/education-under-attack>

\section{Avrupa İnsan Hakları Mahkemesi Kaynakları ve Kararları}

Council of Europe/European Court of Human Rights, 'Guide on Article 2 of Protocol No. 1 to the European Convention on Human Rights, Right to Education' (2019).

Council of Europe/European Court of Human Rights, 'Guide on Article 8 of the European Convention on Human Rights Right to respect for private and family life, home and correspondence' (2020).

Altınay v. Turkey, Başvuru No. 37222/04 (ECtHR, 9 July 2013).

Amanda Kosa v. Hungary, Başvuru No. 53461/15 (ECtHR, 21 November 2017).

Appel-Irrgang and Others v. Germany, Başvuru No. 45216/07 (ECtHR, 6 October 2009).

Bulski v. Poland, Başvuru No. 46254/99 ve 31888/02 (ECtHR, 30 November 2004).

Çam v. Turkey, Başvuru No. 51500/08 (ECtHR, 23 February 2016).

D.H. And Others v. The Czech Republic, Başvuru No. 57325/00 (ECtHR, 13 November 2007).

Enver Şahin v. Turkey, Başvuru No. 23065/12 (ECtHR, 30 January 2018).

Folgerø and Others v. Norway, Başvuru No. 15472/02 (ECtHR, 29 June 2007). 
Horváth And Kiss v. Hungary, Başvuru No. 11146/11 (ECtHR, 29 January 2013).

Kalkanlı v. Turkey, Başvuru No. 2600/04 (ECtHR, 13 January 2009).

Lautsi and Others v. Italy, Başvuru No. 30814/06 (ECtHR, 18 March 2011).

Lavida And Others v. Greece, Başvuru No. 7973/10 (ECtHR, 30 May 2013).

Leyla Şahin v. Turkey, Başvuru No. 44774/98 (ECtHR, 10 November 2005).

Martin Klerks v.Netherlands, Başvuru No. 25212/94 (ECtHR, 4 July 1995).

Mcintyre v. The United Kingdom, Başvuru No. 29046/95(ECtHR, 21 October 1998).

Memlika v. Greece, Başvuru No. 37991/12 (ECtHR, 6 October 2015).

Oršuš and Others v. Croatia, Başvuru No. 15766/03 (ECtHR, 16 March 2020).

Osmanoğlu and Kocabaşv v. Switzerland, Başvuru No. 29086/12 (ECtHR, 10 January 2017).

Ponomaryovi v. Bulgaria, Başvuru No. 5335/05, (ECtHR, 21 June 2011).

Simpson v. The United Kingdom, Başvuru No. 14688/89 (ECtHR, 4 December 1989).

Timishev v. Russia, Başvuru No. 55762/00 ve 55974/00, (ECtHR, 13 December 2005).

Y v. Turkey, Başvuru No. 648/10, (ECtHR, 17 February 2015).

Zv. Finland, Başvuru No. 22009/93 (ECtHR, 25 February 1997).

\section{Federal Almanya Cumhuriyeti Mahkeme Kararları ve İnternet Kaynakları}

Bundesverfassungsgericht, 1 BvL 3/14, 19 Dezember $2017<$ https://www.bundesverfassungsgericht. de/e/ls20171219_1bvl000314.html > erişim tarihi 14 Mayıs 2020.

Bundesverwaltungsgericht, BVerwG, Beschluss vom 13.05.2004 - 6 B $25.04<$ https://www.bverwg. de/130504B6B25.04.0> erişim tarihi 14 Mayıs 2020.

Oberverwaltungsgericht Berlin-Brandenburg, 'Berliner Abiturprüfungen können fortgesetzt werden - 17/20' <https://www.berlin.de/gerichte/oberverwaltungsgericht/presse/ pressemitteilungen/2020/pressemitteilung.923794.php> erişim tarihi 14 May1s 2020.

Verwaltungsgericht Berlin, 'Kein Fernbleiben von schriftlicher Abiturprüfung wegen Coronagefahren (Nr. 21/20020)' <https://www.berlin.de/gerichte/verwaltungsgericht/presse/ pressemitteilungen/2020/pressemitteilung.922000.php> erişim tarihi 14 May1s 2020.

Verwaltungsgericht Berlin, 'Keine Verschiebung der Abiturprüfung wegen erschwerter Vorbereitung (Nr. 22/2020'<https://www.berlin.de/gerichte/verwaltungsgericht/presse/pressemitteilungen/ pressemitteilung.922898.php> erişim tarihi 14 Mayıs 2020;

Verwaltungsgericht Wiesbaden, 'Corona-Krise begründet keinen Anspruch auf Freistellung von den Abiturprüfungen' <https://verwaltungsgerichtsbarkeit.hessen.de/pressemitteilungen/ corona-krise-begr $\% \mathrm{C} 3 \% \mathrm{BCndet-keinen-anspruch-auf-freistellung-von-den-}$ abiturpr\%C3\%BCfungenn > erişim tarih 14 Mayıs 2020.

\section{Diğer İnternet Kaynakları}

American Association of University Professors, 'Principles for Higher Education Response to COVID-19' (13 March 2020) < https://www.aft.org/sites/default/files/covid19_aft-aaup_ guidanceprinciples_031320.pdf $>$ erişim tarihi 15 Mayıs 2020.

Council of Europe, European Court of Human Rights, Prepatory Work on Article 2 of the Protocol to the Convention, Information Document prepared by the Registry of the Court (9 May 1967) Strasbourg, CDH (67) $2<$ https://www.echr.coe.int/LibraryDocs/Travaux/ECHRTravaux-P1-2CDH(67)2-BIL2292567.pdf> erişim tarihi 12 Ağustos 2020. 
'Entschädigungen für Betriebsschließungen nach aktueller Rechtslage unwahrscheinlich' (Noerr, 9 April 2020) <https://www.noerr.com/de/newsroom/news/entschadigungen-furbetriebsschliessungen-nach-aktueller-rechtslage-unwahrscheinlich> erişim tarihi 18 Mayıs 2020.

European Institute on Gender Equality , 'Covid-19 and Gender Equality'> https://eige.europa.eu/ topics/health/covid-19-and-gender-equality> erişim tarihi 9 Mayıs 2020.

Güvenli Okul Bildirgesi <http://www.protectingeducation.org/sites/default/files/documents/safe schools_declaration_turkish.pdf $>$.

Ministerium für Schule und Bildung des Landes Nordrhein-Westfalen <https://www. schulministerium.nrw.de/docs/Recht/Schulgesundheitsrecht/Infektionsschutz/300-Coronavirus/ index.html > erişim tarihi 15 Mayıs 2020.

'Okulları Birlikte Açacağız’ (Milli Eğitim Bakanlığı, 12 Ağustos 2020) <http://www.meb.gov.tr/ okullari-birlikte-acacagiz/haber/21424/tr> erişim tarihi 15 Ağustos 2020.

Österreich Bundesministerium für Bildungs, Wissenschaft und Forschung, 'Studienförderung: Sommersemester 2020 als „neutrales Semester"' (31 Mart 2020) <https://www.brg14.at/ wpcontent/uploads/Erlass_Neutrales_Semester.pdf> erişim tarih 13 Mayıs 2020.

Österreich Bundesministerium für Bildungs, Wissenschaft und Forschung 'Coronavirus (COVID-19): FAQ zu rechtlichen Fragestellungen (Beihilfen, Studienrecht) - Stand: 13. Mai 2020' <https://www.bmbwf.gv.at/Themen/Hochschule-und-Universit\%C3\%A4t/Aktuelles/ corona/corona_faq.html> erişim tarihi 13 Mayıs 2020.

'Pandemi Günlerinde Türk Yükseköğretimi’ (YÖK, 20 Nisan 2020) <https://covid19.yok.gov. tr/Sayfalar/HaberDuyuru/pandemi-gunlerinde-turk-yuksekogretimi.aspx $>$ erişim tarihi 15 Ağustos 2020.

The School Superintendence Association, 'Student Privacy During the COVID-19 Pandemic' (20 March 2020) <https://iapp.org/media/pdf/resource_center/fpf_student_privacy_during covid_19_pandemic.pdf>

United States Department of Education Office for Civil Rights, 'Fact Sheet: Addressing the Risk of COVID-19 in Schools While Protecting the Civil Rights of Students' (16 Mart 2020). 


\section{Ekler}

\section{Ek-1: BM İnsan Hakları Evrensel Beyannamesi}

\section{"Madde 26}

1. Herkes eğitim hakkına sahiptir. Eğitim, en azından ilk ve temel eğitim aşamasında parasızdır. İlköğretim zorunludur. Teknik ve mesleksel eğitim herkese açıktır. Yüksek öğretim, yeteneklerine göre herkese tam bir eşitlikle açık olmalıdır.

2. Eğitim insan kişiliğini tam geliştirmeye ve insan haklarıyla temel özgürlüklere saygıyı güçlendirmeye yönelik olmalıdır. Eğitim, bütün uluslar, ırklar ve dinsel topluluklar arasında anlayış, hoşgörü ve dostluğu özendirmeli ve Birleşmiş Milletlerin barışı koruma yolundaki çalışmalarını geliştirmelidir.

3. Çocuklara verilecek eğitimin türünü seçmek, öncelikle ana ve babanın hakkıdır ${ }^{150}$."

\section{Ek-2 BM Ekonomik, Sosyal, Kültürel Haklar Sözleşmesi-Eğitim Hakkı "Madde 13}

\section{Eğitim hakkı}

1. Bu Sözleşmeye Taraf Devletler, herkese eğitim hakkı tanır. Sözleşmeci Devletler, eğitimin insan kişiliğinin ve onurunun tam olarak gelişmesine ve insan haklarına ve temel özgürlüklere saygıyı güçlendirmesine yönelik olarak verilmesi konusunda birleşirler. Devletler ayrıca herkesin özgürlükçü topluma etkili bir biçiminde katılmasını sağlayacak, bütün uluslar ile bütün ırksal, etnik ve dinsel gruplar arasında anlayış, hoşgörü ve dostluğu geliştirecek ve Birleşmiş Milletlerin barışın korunması için yaptığı faaliyetlerini ilerletecek bir eğitim verilmesi konusunda anlaşırlar.

2. Bu Sözleşmeye Tarafolan Devletler eğitim hakkının tam olarak gerçekleşmesini sağlamak amaciyla, şu yükümlülükleri yerine getir:

a) İlköğretim zorunludur ve herkese ücretsiz ilköğretim sağlanır;

b) Teknik ve mesleki eğitim de dahil ikinci eğitimin farkla türleri ve özellikle başlangıçta verilecek ücretsiz geliştirme eğitimi gibi her türlü uygun vasıtalarla, kural olarak herkesin girmesine ve yararlanmasına açık duruma getirilir.

150 Çeviri BM-Türkiye resmi internet sitesinden alınmıştır. <http://www.unicankara.org.tr/doc_pdf/h_rigths_turkce.pdf $>$ erişim tarihi 15 Ağustos 2020. 
c) Yüksek öğrenim, özellikle başlangıçta verilecek ücretsiz geliştirme eğitimi gibi her türlü uygun vasitalarla, yetenek ölçüsüne göre herkesin eşit olarak yararlanmasına açık duruma getirilir.

d) İlk eğitimin bütün dönemini tamamlayamamış veya bu eğitimi hiç alamamış olan kişiler, mümkün olduğu kadar temel eğitim almaya teşvik edilir veya bu eğitimi almaya mecbur tutulur.

e) Her düzeydeki okul sistemlerinin geliştirilmesi aktif olarak sağlanmaya çalışılır; yeterli bir burs sistemi kurulur ve öğretmenlerin maddi koşulları sürekli olarak iyileştirilir.

3. Bu Sözleşmeye Taraf Devletler, annebabaların ve uygulanması mümkünse vasilerin de, çocuklarını devlet tarafından kurulan okulların dışında varolan ama Devlet tarafindan konulmuş veya onaylanmış standartların asgari şartlarına sahip bulunan okullara gönderme ve kendi inançlarına uygun bir biçimde çocuklarına dinsel ve ahlaki eğitim sağlama haklarına saygı gösterir.

4. $\mathrm{Bu}$ maddenin hiç bir hüküm, bu maddenin birinci fikrasında belirtilen prensiplerin özel eğitim kurumlarında her zaman yerine getirilmesi ve özel eğitim kurumlarında verilen eğitimin Devlet tarafından gösterilen asgari standartlara uyması halleri saklı kalmak kaydıyla, kişilere ve kuruluşlara eğitim kurumları kurma ve yönetme serbestisi verecek şekilde yorumlanamaz.

\section{Madde 14}

\section{Zorunlu ilköğretimi sağlama yükümlülüğü}

Bu Sözleşmeye Taraf Devletlerden, Sözleşmeye Taraf olduğu sırada anavatanında veya kendisinin egemenliği altında bulunan diğer ülkelerde parasız ve zorunlu ilköğretimi sağlayamamış olan Devletler, iki yıl içinde herkes için parasız zorunlu eğitimin prensiplerini ortaya koyan bir plan hazırlar ve bu planın makul bir süreyi aşmayacak şekilde kaç yıl içinde uygulanacağını gösteren ayrıntılı bir uygulama planı hazırlar ve kabul eder ${ }^{151}$."

\section{Ek-3: BM Çocuk Hakları Sözleşmesi-Sağlık Hakkı}

\section{"Madde 24}

Taraf Devletler, çocuğun olabilecek en iyi sağlık düzeyine kavuşma, tıbbi bakım ve rehabilitasyon hizmetlerini veren kuruluşlardan yararlanma hakkını tanırlar. Taraf

\footnotetext{
151 Çeviri BM-Türkiye resmi internet sitesinden alınmıştır. < http://www.unicankara.org.tr/doc_pdf/metin134.pdf > erişįim tarihi 15 Ağustos 2020.
} 
Devletler, hiçbir çocuğun bu tür tıbbi bakım hizmetlerinden yararlanma hakkından yoksun bırakılmamasını güvence altına almak için çaba gösterirler.

Taraf Devletler, bu hakkın tam olarak uygulanmasını takip ederler ve özellikle:

Bebek ve çocuk ölüm oranlarının düşürülmesi;

Bütün çocuklara gerekli tıbbi yardımın ve tıbbi bakımın; temel sağlık hizmetlerinin geliştirilmesine önem verilerek sağlanması;

Temel sağlık hizmetleri çerçevesinde ve başka olanakların yanısıra, kolayca bulunabilen tekniklerin kullanılması ve besleyici yiyecekler ve temiz içme suyu sağlanması yoluyla ve çevre kirlenmesinin tehlike ve zararlarını gözönüne alarak, hastalık ve yetersiz beslenmeye karşı mücadele edilmesi;

Anneye doğum öncesi ve sonrası uygun bakımın sağlanması;

Bütün toplum kesimlerinin özellikle ana-babalar ve çocukların, çocuk sağlığı ve beslenmesi, anne sütü ile beslenmenin yararları, toplum ve çevre sağlığ 1 ve kazaların önlenmesi konusunda temel bilgileri elde etmeleri ve bu bilgileri kullanmalarına yardimc1 olunmasi;

Koruyucu sağlık bakımlarının, ana-babaya rehberliğini, aile planlanması eğitimi ve hizmetlerinin geliştirilmesi; amaçlarıyla uygun önlemleri alırlar.

Taraf Devletler, çocukların sağlığı için zararlı geleneksel uygulamaların kaldırılması amacıyla uygun ve etkili her türlü önlemi alırlar.

Taraf Devletler, bu maddede tanınan hakkın tam olarak gerçekleştirilmesini tedricen sağlamak amacıyla uluslararası işbirliğinin geliştirilmesi ve teşviki konusunda karşılıklı olarak söz verirler. Bu konuda gelişmekte olan ülkelerin gereksinimleri özellikle gözönünde tutulur ${ }^{152}$."

\section{Ek-4: BM Çocuk Hakları Sözleşmesi-Ĕgitim Hakkı}

\section{"Madde 28}

Taraf Devletler, çocuğun eğitim hakkını kabul ederler ve bu hakkın firsat eşitliği temeli üzerinde tedricen gerçekleştirilmesi görüşüyle özellikle:

İlköğretimi herkes için zorunlu ve parasız hale getirirler;

Ortaöğretim sistemlerinin genel olduğu kadar mesleki nitelikte de olmak üzere çeşitli biçimlerde örgütlenmesini teşvik ederler ve bunların tüm çocuklara açık

152 Çeviri BM-Türkiye resmi internet sitesinden alınmıştır. <https://www.unicef.org/turkey/\%C3\%A7ocuk-haklar\%C4\%B1nadair-s\%C3\%B6zle\%C5\%9Fme> erişim tarihi 15 Ağustos 2020. 
olmasını sağlarlar ve gerekli durumlarda mali yardım yapılması ve öğretimi parasız k1lmak gibi uygun önlemleri alırlar;

Uygun bütün araçları kullanarak, yüksek öğretimi yetenekleri doğrultusunda herkese açık hale getirirler;

Eğitim ve meslek seçimine ilişkin bilgi ve rehberliği bütün çocuklar için elde edilir hale getirirler;

Okullarda düzenli biçimde devamın sağlanması ve okulu terketme oranlarının düşürülmesi için önlem alırlar.

Taraf Devletler, okul disiplininin çocuğun insan olarak taşıdığı saygınlıkla bağdaşır biçimde ve bu Sözleşme' ye uygun olarak yürütülmesinin sağlanması amacıyla gerekli olan tüm önlemleri alırlar.

Taraf Devletler eğitim alanında, özellikle cehaletin ve okuma yazma bilmemenin dünyadan kaldırılmasına katkıda bulunmak ve çağdaş eğitim yöntemlerine ve bilimsel ve teknik bilgilere sahip olunmasını kolaylaştırmak amacıyla uluslararası işbirliğini güçlendirir ve teşvik ederler. Bu konuda, gelişmekte olan ülkelerin gereksinimleri özellikle gözönünde tutulur.

\section{Madde 29}

Taraf Devletler çocuk eğitiminin aşağıdaki amaçlara yönelik olmasını kabul ederler:

Çocuğun kişiliğinin, yeteneklerinin, zihinsel ve bedensel yeteneklerinin mümkün olduğunca geliştirilmesi;

İnsan haklarına ve temel özgürlüklere, Birleşmiş Milletler Andlaşmasında benimsenen ilkelere saygısının geliştirilmesi;

Çocuğun ana-babasına, kültürel kimliğine, dil ve değerlerine, çocuğun yaşadığ1 veya geldiği menşe ülkenin ulusal değerlerine ve kendisininkinden farklı uygarlıklara saygısının geliştirilmesi;

Çocuğun, anlayışı, barış, hoşgörü, cinsler arası eşitlik ve ister etnik, ister ulusal, ister dini gruplardan, isterse yerli halktan olsun, tüm insanlar arasında dostluk ruhuyla, özgür bir toplumda, yaşantıyı, sorumlulukla üstlenecek şekilde hazırlanması;

Doğal çevreye saygısının geliştirilmesi.

$\mathrm{Bu}$ maddenin veya 28'inci maddenin hiçbir hükmü gerçek ve tüzel kişilerin öğretim kurumları kurmak ve yönetmek özgürlüğüne, bu maddenin 1 inci fikrasında 
belirtilen ilkelere saygı gösterilmesi ve bu kurumlarda yapılan eğitimin Devlet tarafından konulmuş olan asgari kurallara uygun olması koşuluyla, aykırı sayılacak biçimde yorumlanmayacaktır ${ }^{153}$."

153 Çeviri BM-Türkiye resmi internet sitesinden alınmıştır. <https://www.unicef.org/turkey/\%C3\%A7ocuk-haklar\%C4\%B1nadair-s\%C3\%B6zle\%C5\%9Fme> erişim tarihi 15 Ağustos 2020. 